\title{
Euphorbiaceae na Serra Geral de Licínio de Almeida, Bahia, Brasil'
}

\author{
Euphorbiaceae in Serra Geral of Licínio de Almeida, Bahia, Brazil
}

\author{
Fernanda Hurbath ${ }^{2,5}$, Daniela Santos Carneiro Torres ${ }^{3} \&$ Nádia Roque $^{4}$
}

\begin{abstract}
Resumo
Euphorbiaceae possui grande representatividade no semiárido nordestino, sendo uma das famílias consideradas típicas da Caatinga. O objetivo deste estudo foi realizar o levantamento florístico de Euphorbiaceae na Serra Geral de Licínio de Almeida, incluindo chave de identificação, descrições, comentários e ilustrações. A área localiza-se na região central da Cadeia do Espinhaço em uma faixa oeste do município de Licínio de Almeida, sudoeste da Bahia. Foram registradas 51 espécies distribuídas em 14 gêneros: Croton (23 spp.), Euphorbia (6 spp.), Microstachys (4 spp.), Manihot (3 spp.), Acalypha, Cnidoscolus, Dalechampia, Sebastiania e Stillingia (2 spp. cada), Alchornea, Astraea, Gymnanthes, Maprounea e Tragia (1 sp. cada). Três espécies são endêmicas da Bahia (Croton imbricatus, Microstachys uleana e Sebastiania catingae). Quatro são novas ocorrências para o estado (Acalypha multicaulis, Euphorbia attastoma, E. setosa e Stillingia trapezoidea).
\end{abstract}

Palavras-chave: Cadeia do Espinhaço, florística, morfologia, semiárido, taxonomia.

\begin{abstract}
Euphorbiaceae has a large representation in the semi-arid region of Brazil, and is considered one of the families that characterize Caatinga. The aim of this study was to conduct a floristic survey of the family Euphorbiaceae to Serra Geral of Licínio de Almeida including identification key, descriptions, comments and illustrations. The area is located in Espinhaço Range and occupies a long area west of the municipality of Licínio de Almeida. A number of 51 species distributed in 14 genera were collected: Croton (23 spp.), Euphorbia (6 spp.), Microstachys (4 spp.), Manihot (3 spp.), Acalypha, Cnidoscolus, Dalechampia, Sebastiania e Stillingia (2 spp. each), Alchornea, Astraea, Gymnanthes, Maprounea and Tragia (1 sp. each). Three espécies are endemic to Bahia (Croton imbricatus, Microstachys uleana, Sebastiania catingae), four are new records to the State (Acalypha multicaulis, Euphorbia attastoma, E. setosa, and Stillingia trapezoidea).
\end{abstract}

Key words: Espinhaço Range, floristic, morphology, caatinga, taxonomy.

\section{Introdução}

Euphorbiaceae possui 240 gêneros e aproximadamente 6300 espécies (Wurdack \& Davis 2009). No Brasil existem 64 gêneros e 940 espécies, sendo 68\% endêmicas do país (BFG 2015). É considerada uma das famílias típicas da Caatinga devido à sua grande representatividade no semiárido nordestino (Zappi 2008), com cerca de 78 espécies endêmicas deste bioma (BFG 2015). Atualmente encontram-se listadas 48 gêneros e
361 espécies para o Nordeste brasileiro, sendo 109 espécies endêmicas da região (Zappi 2008; BFG 2015).

A família apresenta elevada diversidade morfológica caracterizando-se principalmente pelas flores unissexuais, folhas geralmente alternas, látex em geral presente, ovário súpero, na maioria tricarpelar e trilocular, com um óvulo por lóculo. O fruto é, geralmente, um esquizocarpo, com sementes de tegumento fino, ósseo ou carnoso,

\footnotetext{
${ }^{1}$ Parte da dissertação de Mestrado da primeira autora.

${ }^{2}$ Universidade do Estado da Bahia, Programa de Pós-graduação em Biodiversidade Vegetal, Depto. Educação - Campus VIII, Paulo Afonso; Depto. Ciências Exatas e da Terra - Campus II, Alagoinhas; Depto. Educação - Campus VII, Senhor do Bonfim, BA, Brasil.

${ }^{3}$ Universidade Estadual de Feira de Santana, Depto. Ciências Biológicas. Av. Trasnordestina s/n, Novo Horizonte, 44036-900, Feira de Santana, BA, Brasil.

${ }^{4}$ Universidade Federal da Bahia, Inst. Biologia, Depto. Botânica, R. Barão de Geremoabo s/n, Campus Universitário de Ondina, 40171-970, Salvador, BA, Brasil.

${ }^{5}$ Autora para correspondêcia: fhurbath@gmail.com
} 
frequentemente providas de carúncula e de endosperma abundante (Webster 1994; RadcliffeSmith 2001; Judd et al. 2009).

Licínio de Almeida (Fig. 1) localiza-se na região setentrional da Serra do Espinhaço que abrange desde o município de Bocaiúva (MG) até Caetité (BA). Segundo a Portaria no 9 (MMA 2007), para a Caatinga, a área onde insere-se a "Serra Geral de Licínio de Almeida" classifica-se como insuficientemente conhecida e com urgência de ação extremamente alta. Taylor \& Zappi (2004) já haviam ressaltado a importância em considerar a SGLA, e áreas próximas, como prioritárias para conservação devido à presença de espécies de Cactaceae vulneráveis (VU), em perigo (EN) e critamente em perigo (CR).

No município de Licínio de Almeida, a situação é agravada, tendo em vista que lá não há áreas protegidas por lei, ou seja, inexistem Unidades de Conservação na região. $\mathrm{O}$ manejo inadequado dos solos, a prática de queimadas, as explorações minerais impróprias ou clandestinas (especialmente de manganês e ametista), a formação de vossorocas e o assoreamento de nascentes são ameaças constantes à manutenção dos ecossistemas locais.

O levantamento da flora da Serra Geral de Licínio de Almeida é o primeiro passo para a prática da conservação e a preservação dessa região, além de subsidiar o interesse municipal na criação de algum tipo de Unidade de Conservação na região.

Nesse sentido, o objetivo do presente estudo foi realizar o levantamento florístico e o tratamento taxonômico das espécies da família Euphorbiaceae na SGLA, uma área com carência em pesquisas botânicas, que trará um importante avanço no conhecimento dos padrões de distribuição das espécies encontradas ao longo da Cadeia do Espinhaço, além de colaborar com o incremento de dados da família junto à Flora do Brasil e dar subsídios para a preservação da biodiversidade.

\section{Material e Métodos}

A SGLA encontra-se nos limites do município de Licínio de Almeida, à sudoeste da Bahia, em um trecho central da Cadeia do Espinhaço conhecido como Espinhaço Setentrional (Carneiro-Chaves et al. 2005), ou região Norte da Serra do Espinhaço (Taylor \& Zappi 2004). Localiza-se entre as coordenadas $14^{\circ} 25^{\prime}-14^{\circ} 50^{\prime} \mathrm{S}$ e $42^{\circ} 35^{\prime}-42^{\circ} 30^{\prime} \mathrm{W}$, apresentando área aproximada de 24.000 ha e altitudes que variam de 700 a 1230 m.s.m. (Fig. 1). Licínio de Almeida encontra-se entre os municípios de Caetité ao norte, Caculé ao norte e leste, Pindaí e Urandi a oeste, e Jacaraci ao leste e sul. Apresenta clima semiárido com temperatura média anual de $21^{\circ} \mathrm{C}$ e pluviosidade anual variando entre 500 a $1000 \mathrm{~mm}$. No seu território encontra-se a nascente do Rio do Antônio, afluente do Rio de Contas (Costa 2005). A fitofisionomia predominante na SGLA é a de Savana Arborizada (cerrado) sensu IBGE (2012), mas também são encontradas Savana Estépica (caatinga) e Savana Parque (campos rupestres), sendo que a primeira pode apresentar-se sobre afloramento rochoso (caatinga sobre afloramento rochoso). Pode-se observar também florestas estacionais semideciduais associadas ou não a córregos e rios (matas de galeria), e nas encostas das serras (formação florestal submontana), além de muitos ecótonos entre caatinga e cerrado.

Para o levantamento florístico foram realizadas dez expedições, entre os meses de julho de 2011 e novembro de 2013, com amostragem em todos os períodos sazonais. Os materiais coletados foram herborizados e encontram-se depositados no herbário ALCB, com duplicatas enviadas aos herbários HUNEB, HUEFS e SP. Para a identificação dos espécimes, foram realizadas visitas às coleções dos herbários ALCB, CEPEC, CENARGEN, HUEFS, MBM, SP, SPF, RB e UB (acrônimos segundo Thiers, continuamente atualizado).

Gêneros com mais de uma espécie foram acompanhados de descrição, utilizando a terminologia de Radford et al. (1986) e Harris \& Harris (1994), e especificamente para a terminologia dos tricomas encontrados no gênero Croton utilizou-se Webster et al. (1996). Pecíolos e pedicelos foram considerados sésseis quando mediam até $0,1 \mathrm{~mm}$ de compr., e subsésseis quando menores que $0,5 \mathrm{~mm}$ de compr. As medidas foram colocadas apenas quando houve variação de subséssil a peciolada ou pedicelada (ex: 0,3-1,9 mm). Para análise e descrição do material, as estruturas reprodutivas foram rehidratadas, algumas espécies foram fixadas em álcool 70\% ainda em campo para facilitar as medições, e os tricomas de Croton foram raspados e feitas lâminas para análise em microscópio binocular Alpax Smart-3B1.

O mapa foi gerado no programa ArcGis com base nas coordenadas anotadas nas expedições e nos espécimes de herbário, através do software ArcGis v.9.3. 


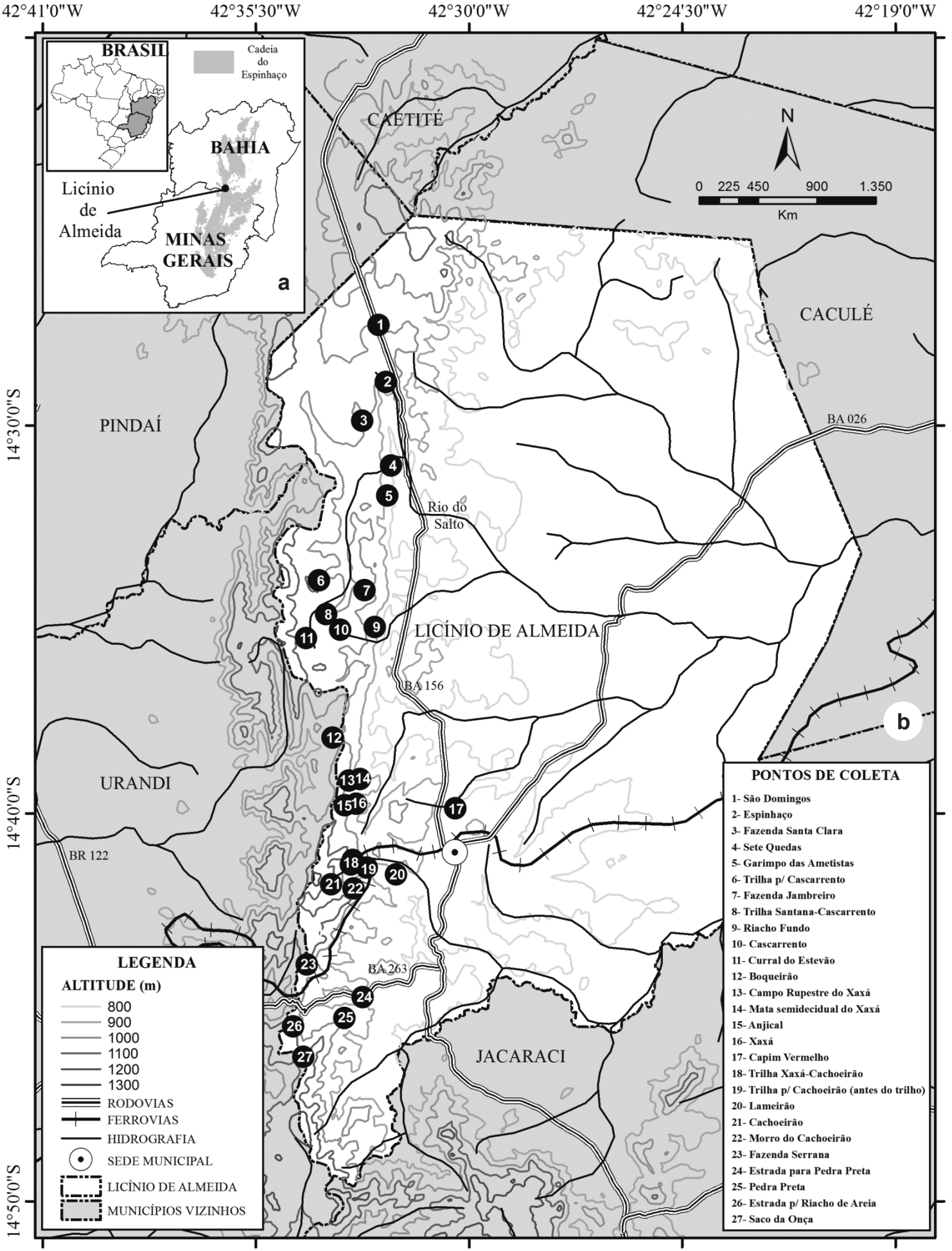

Figuras 1 - a-b. Mapa do município de Licínio de Almeida e da área de estudo com círculos representando os locais de coleta. Figures 1 -a-b. Map of Licínio de Almeida municipality and of the area of study with circles representing samples locations. 


\section{Resultados e Discussão}

Euphorbiaceae s.s. Juss, Gen. Pl.: 384. 1789.

Ervas, subarbustos, arbustos, árvores, lianas, monóicas ou dióicas, perenes ou anuais, ramos suculentos ou não; tricomas presentes ou ausentes; espinhos presentes ou ausentes; látex presente ou ausente, tóxico. Folhas geralmente alternas, ou opostas, ou verticiladas, peltadas ou não, limbo simples ou raramente composto, inteiro ou lobado, venação actinódroma ou camptódroma, margem lisa, denteada, serreada, crenada ou variações destas, frequentemente com glândulas na base do limbo, pecioladas ou sésseis, com ou sem estípulas. Inflorescência terminal, axilar ou lateral, cimosa, tirsiforme, paniculada, racemosa ou flores agregadas em um pseudanto envolvidas por duas brácteas involucrais (Dalechampia), ou em um invólucro formado por brácteas conadas formando um pseudanto do tipo ciátio (Euphorbia), ou flores isoladas. Flores unissexuais, geralmente actinomorfas, diminutas; pediceladas ou sésseis; aclamídeas, monoclamídeas ou diclamídeas; sépalas livres ou unidas; pétalas livres, raro unidas, ou ausentes; glândulas nectaríferas presentes ou ausentes, às vezes unidas formando um disco inteiro ou lobado, disco nectarífero nas flores pistiladas presente ou ausente, quando presente, hipógino, inteiro ou lobado, raro formado por glândulas separadas; estames 1-numerosos, livres ou conados; estaminódios presentes ou ausentes; ovário sincárpico, súpero, séssil ou estipitado, frequentemente trilocular, 1 óvulo por lóculo, geralmente anátropo; estiletes livres ou conados, inteiros ou partidos. Fruto geralmente um esquizocarpo deiscente geralmente em três ou raramente duas cocas, columela geralmente persistente. Sementes com ou sem carúncula.

\section{Chave de identificação dos gêneros de Euphorbiaceae da SGLA}

1. Folhas com limbo lobado.

2. Tricomas urticantes por quase toda a planta (normalmente é possível visualizar o exsudado em seu interior); inflorescências em pseudantos ou em dicásios; estames unidos em uma coluna.

3. Trepadeiras; látex ausente; inflorescências em pseudantos; estiletes inteiros

6. Dalechampia

3'. Arbustos; látex presente; inflorescências em dicásios; estiletes multífidos

4. Cnidoscolus

2'. Tricomas não urticantes; inflorescências em tirsos racemiformes, racemos ou panículas; estames livres.

4. Ervas; tricomas estrelados; inflorescências em tirsos racemiformes; sépalas das flores estaminadas livres

4'. Arbustos; tricomas tectores; inflorescências em racemos ou panículas; sépalas das flores estaminadas unidas. 9. Manihot

1'. Folhas com limbo inteiro.

5. Plantas com tricomas estrelados ou tectores urticantes (normalmente é possível visualizar o exsudato em seu interior).

6. Arbustos; látex presente; estiletes bífidos-multífidos

5. Croton

6'. Árvores ou ervas escandentes; látex ausente; estiletes inteiros.

7. Árvores; tricomas estrelados; flores pistiladas com 3 sépalas

2. Alchornea

7'. Ervas escandentes; tricomas tectores urticantes; flores pistiladas com 6 sépalas

5'. Plantas glabras ou com tricomas tectores não urticantes.

8. Inflorescências em pseudantos do tipo ciátio; flores aclamídeas 7. Euphorbia

8'. Inflorescências espiciformes, flores monoclamídeas.

9. Estames 5-numerosos; estiletes multífidos... 1. Acalypha

9'. Estames 2-3; estiletes inteiros.

10. Glândulas laminares presentes na face abaxial do limbo; flores pistiladas com pedicelos $1,8-6,1 \mathrm{~mm}$ compr.

11. Inflorescências tirsos espiciformes; brácteas das flores estaminadas com glândulas subsésseis .... 8. Gymnanthes 
11'. Inflorescências tirsos globosos; brácteas das flores estaminadas com glândulas estipitadas

10'. Glândulas laminares ausentes na face abaxial do limbo; flores pistiladas sésseis a subsésseis (menores que $0,5 \mathrm{~mm}$ de compr.).

12. Flores estaminadas dispostas em címulas com 3-23 flores; 2 estames.

13. Stillingia

12'. Flores estaminadas dispostas em címulas com 3 flores; 3 estames.

13. Sépalas das flores estaminadas livres; frutos com cornículos, raro lisos; sementes com carúncula estipitada 11. Microstachys

13'. Sépalas das flores estaminadas unidas; frutos desprovidos de cornículos; sementes com carúncula séssil.

12. Sebastiania

1. Acalypha L., Sp. Pl. 2: 1003. 1753.

Ervas, subarbustos, arbustos, raro árvores, monóicos, raro dióicos; indumento com tricomas tectores, raro estrelados, frequentemente glandulares; látex ausente. Folhas alternas, limbo inteiro, estipuladas; glândulas ausentes na base do limbo. Inflorescências axilares ou terminais, flores estaminadas geralmente em glomérulos formando uma inflorescência espiciforme, flores pistiladas geralmente na base, pode apresentar flor pistilada alomórfica. Flores estaminadas monoclamídeas, sépalas geralmente unidas, 4-partidas; estames 8(12), livres, anteras vermiformes. Flores pistiladas monoclamídeas, sépalas geralmente unidas; ovário trilocular; estiletes multífidos, geralmente vináceos. Fruto cápsula septicida. Sementes com ou sem carúncula.

Gênero pantropical com ca. 450 espécies, das quais 48 ocorrem no Brasil (Radcliffe-Smith 2001; BFG 2015). Caracteriza-se pelo limbo com margem variando de crenada a serreada, inflorescência geralmente espiciforme, anteras vermiformes e estiletes geralmente ramificados, conspícuos e vináceos (Radcliffe-Smith 2001). Na SGLA, está representado por duas espécies.

\section{Chave de identificação das espécies de Acalypha da SGLA}

1. Tricomas estrelados; face abaxial do limbo estrigosa; estípulas estreito-lanceoladas; margens das brácteas das flores pistiladas fimbriado-glandulosas 1.1. A.brasiliensis

1'. Tricomas tectores; face abaxial do limbo glabrescente; estípulas triangulares; margens das brácteas das flores pistiladas denteadas 1.2. A. multicaulis

1.1 Acalypha brasiliensis Müll. Arg., Linnaea 34: 37.1865.

Subarbustos eretos, ca. $0,5 \mathrm{~m}$ alt; ramos não viscosos, setosos, tricomas estrelados. Limbos membranáceos, 4,9-7,7 × 3-4,6 cm, ovados, venação actinódroma, ápice acuminado a caudado, margem denteada a levemente crenada, eglandulosa, base arredondada, face adaxial e abaxial estrigosa, ambas com tricomas estrelados, face abaxial verde; pecíolos 1,5-2,8 cm compr.; estípulas $2,2-3,8 \times 0,4-0,5 \mathrm{~mm}$, estreitolanceoladas, margem inteira. Inflorescências axilares, tirsos espiciformes não terminando em flor pistilada alomórfica, 1,8-2,8 cm compr.; raque pubescente; flores estaminadas em glomérulos distribuídos ao longo da raque; brácteas ca. $0,8-1 \times 0,4-0,6 \mathrm{~mm}$, ovadas, margem inteira; flores pistiladas 2 por bráctea, na base da raque, brácteas 4,7-5 × 2,7-3,8 mm, reniformes, margem fimbriado-glandulosa. Flores estaminadas vináceas, $1-1,2 \mathrm{~mm}$ compr.; pedicelos $0,4-0,7$ mm compr.; sépalas $4,0,2-0,4 \times 0,2-0,3 \mathrm{~mm}$, ovadas a triangulares, margem inteira, face abaxial hirsutulosa; estames 5-6, 0,1-0,2 mm compr. Flores pistiladas esverdeadas, $2-2,5 \times 0,5-1 \mathrm{~mm}$, sésseis; sépalas 3,1-1,1 × 0,3-0,4 mm, ovadas, unidas na base, margem ciliada, face abaxial serícea; ovários 1-1,4 × 1-1,6 mm, globosos, hirsutos; estiletes livres, multífidos, castanhos a vináceos, glabros. Flor pistilada alomórfica ausente. Frutos e sementes não observados.

Material examinado: Distrito de São Domingos, Fazenda São Domingos, 10.XII.2009, fl., E. Melo 7425 (ALCB). 
Distribuição: A espécie é endêmica do Brasil e ocorre em quase todas as regiões, exceto na região Norte (BFG 2015).

Comentários: Acalypha brasiliensis difere de A. multicaulis Müll. Arg. por apresentar tricomas estrelados (vs. tectores), estípulas estreitolanceoladas ( $v s$. triangulares) e margens das brácteas das flores pistiladas fimbriado-glandulosas (vs. denteadas). Na SGLA, a espécie é encontrada crescendo em fitofisionomia de ecótono entre caatinga e cerrado.

1.2 Acalypha multicaulis Müll. Arg., Linnaea 34: 53. 1865.

Subarbustos eretos, ca. $0,5 \mathrm{~m}$ alt.; ramos não viscosos, pubescentes, tricomas tectores. Limbos membranáceos, 3,4-4,8 × 2,1-3,2 cm, ovados, venação actinódroma, ápice acuminado, margem denteada, eglandulosa, base aguda a arredondada, face adaxial glabrescente, face abaxial glabrescente, ambas com tricomas tectores, face abaxial vinácea; pecíolos 3-3,4 cm compr.; estípulas $0,4-0,7 \times 0,3-0,4 \mathrm{~mm}$, triangulares, margem inteira. Inflorescências axilares, tirsos espiciformes terminando em 1 flor pistilada alomórfica, 2,1-4,6 cm compr.; raque pubescente; flores estaminadas em glomérulos distribuídos ao longo da raque; brácteas ca. $0,2 \times 0,2 \mathrm{~mm}$, ovadas a elípticas, margem inteira; flores pistiladas 3-4 por bráctea, na base da raque, brácteas $2-5,3 \times$ 3-7,4 mm, reniformes, margem denteada. Flores estaminadas vináceas, $0,6-0,9 \mathrm{~mm}$ compr.; pedicelos $0,4-0,6 \mathrm{~mm}$ compr.; sépalas $4,0,2-0,3$ $\times 0,1-0,2 \mathrm{~mm}$, ovadas, margem inteira, face abaxial glabra; estames 7-9, 0,1-0,2 mm compr. Flores pistiladas castanho-vináceas, 0,6 $\times 0,5$ $\mathrm{mm}$, sésseis; sépalas 3 , ca. $0,4 \times 0,2 \mathrm{~mm}$, ovadas, livres, margem ciliada, face abaxial glabra; ovários $0,5-0,7 \times 0,5-0,7 \mathrm{~mm}$, globosos, hirsutos; estiletes livres, multífidos, vináceos, glabros. Flor pistilada alomórfica ca. 2,3 mm compr.; pedicelo ca. $0,2 \mathrm{~mm}$ compr., abracteolada; sépalas 5 , ovadas, margem inteira; estiletes unidos na base, 2-5-fidos; ovário hirsuto, unilocular, uniovular. Frutos e sementes não observados.

Material examinado: Mata do Xaxá, 21.I.2013, fl., F. Hurbath 453 (ALCB, HUNEB, SP).

Distribuição: A espécie é endêmica do Brasil e ocorre nas regiões Sul, Sudeste e Nordeste (BFG 2015). É aqui registrada pela primeira vez no estado da Bahia.

Comentários: Acalypha multicaulis pode ser reconhecida em campo por apresentar face abaxial do limbo vinácea e pecíolos com comprimento aproximado do limbo. Ver comentários de $A$. brasiliensis. Na SGLA, a espécie foi coletada na localidade do Xaxá, em floresta estacional decidual.

2. Alchornea Sw., Prodr. 6: 98. 1788.

O gênero é pantropical e apresenta ca. 60 espécies, dos quais apenas oito para o Brasil (Secco 2004; BFG 2015). É caracterizado por apresentar plantas dióicas, raro monóicas, com tricomas estrelados, estípulas ausentes (raro presentes), limbo com margem crenada a serreada (raro inteira), ovário que pode apresentar apenas dois carpelos, e sementes ecarunculadas (Secco 2004). Na SGLA, está representado por uma espécie.

2.1 Alchornea glandulosa Poepp. subsp. iricurana (Casar.) Secco., Fl. Neotrop. 93: 78. 2004.

Árvores, ca. $6 \mathrm{~m}$ alt., dióicas; látex ausente; ramos não viscosos, pubescentes, tricomas estrelados sésseis e subsésseis. Folhas alternas, simples; limbos cartáceos, inteiros, 8,8-15 ×6,2-8,6 $\mathrm{cm}$, ovados a elípticos, venação actinódroma, ápice acuminado, margem serreada, eglandulosa, base arredondada a retusa, face adaxial glabrescente, face abaxial esparso-pubescente a glabrescente, ambas com tricomas estrelados, face abaxial verde; glândulas presentes na base do limbo, 2-3, discoides; pecíolos 4,3-7,5 cm compr.; estípulas $0,5-0,7 \times 0,4-0,6 \mathrm{~mm}$, triangulares, margem inteira. Inflorescências axilares, unissexuais, tirsos espiciformes (masculinas) formados por flores em glomérulos ao longo da raque, ou espigas (femininas), 3,1-5,2 cm compr.; raques pubescentes a tomentosas; brácteas incospícuas. Flores estaminadas verdes, em botões, 1-1,2 mm compr.; bractéolas ovadas, ca. $2 \times 0,8 \mathrm{~mm}$; pedicelos ca. 0,2 $\mathrm{mm}$ compr.; sépalas ca. $1 \times 0,7 \mathrm{~mm}$, ovadas, livres, margem inteira, face abaxial glabrescente; pétalas não observadas; estames 6-7, 0,7-0,8 mm compr., filetes achatados, unidos na base. Flores pistiladas verdes, 3,7-6,1 mm compr., sésseis; sépalas 4, ca. $1 \times 1 \mathrm{~mm}$, ovadas, unidas na $1 / 2$ inferior, margem inteira, face abaxial tomentosa; pétalas ausentes; disco nectarífero não observado; ovários 1,3-2,5 $\times 1,2-1,5 \mathrm{~mm}$, ovoides, tomentosos; estiletes $2-3$, levemente unidos na base, glabrescentes. Frutos e sementes não observados.

Material examinado: Fazenda Boqueirão, 15.VII.2011, fl., N. Roque 3224 (ALCB).

Material adicional: BRASIL. PARANÁ: Campo Mourão, Pousada, Fazendinha, 23.V.2005, H.C.L. Geraldino 30 (ALCB). 
Distribuição: Possui distribuição neotropical (Secco 2004), e no Brasil ocorre nas regiões Nordeste, Sudeste, Sul e Centro-Oeste (BFG 2015; Secco 2004).

Comentários: Alchornea glandulosa apresenta duas subespécies no Brasil: Alchornea glandulosa subsp. iricurana difere de $A$. glandulosa subsp. glandulosa por apresentar ápice do limbo acuminado (vs. caudado) e pela distinta distribuição geográfica, já que a segunda é restrita à região amazônica. Na SGLA, é encontrada apenas o espécime feminino em uma mata de galeria em fitofisionomia de caatinga.

3. Astraea Klotzsch, Arch. Naturgesch. 7(1): 194. 1841.

Gênero neotropical representado por dez espécies, das quais cinco ocorrem no Brasil (Caruzo \& Cordeiro 2007; BFG 2015). Caracteriza-se pelo limbo profundamente 3-5-lobado, raramente inteiro, flores estaminadas com sépalas imbricadas, pétalas tomentosas na base com presença de tricomas moniliformes, estiletes avermelhados, multífidos, sementes tetragonais, rugosas e com carúncula presente (Caruzo \& Cordeiro 2007). Na SGLA, está representado por uma espécie.

3.1 Astraea lobata (L.) Klotzsch, Arch. Naturgesch. 7(1): 194. 1841.

Ervas eretas, ca. 0,3 m alt., monóicas; látex translúcido; ramos não viscosos, glabrescentes, tricomas estrelados sésseis. Folhas alternas, simples; limbos membranáceos, palmatífidos, 3-lobados, lobos centrais 7,5-5,3 × 2,8-1,5 cm, lobos laterais 3,9-6,1 × 1,2 cm, lobos elípticos a obovados, venação actinódroma, ápice caudado, margem serreada com glândulas capitadas, base truncada a cuneada, face adaxial glabra a glabrescente, face abaxial glabrescente, ambas com tricomas tectores, face abaxial verde; glândulas ausentes na base do limbo; pecíolos 2,7-3,7 cm compr.; estípulas ca. 3,5 × 0,2 $\mathrm{mm}$, lineares, margem inteira. Inflorescências terminais, tirsos racemiformes, 12,3-15,1 cm compr.; raques glabrescentes; brácteas 3-2 $\times$ $0,2-0,4 \mathrm{~mm}$, ovadas a lanceoladas, margem inteira. Flores estaminadas verdes, 3,5-4,7 mm compr.; pedicelos 2,2-3 mm compr.; sépalas 5, $1,3-1,6 \times 0,8-1 \mathrm{~mm}$, elípticas a ovadas, livres, margem inteira, face abaxial glabra; pétalas 5, $1,2-1,5 \times 0,4-0,6 \mathrm{~mm}$, obovadas; estames $10-11$, 1-2 mm compr., livres. Flores pistiladas verdes,
3,8-4,1 mm compr.; pedicelos ca. $0,8 \mathrm{~mm}$ compr.; sépalas 5, 2,5-3,2 × 0,5-0,7 mm, oblongas, livres, margem com glândulas, face abaxial glabrescente; pétalas ausentes; disco nectarífero 5-lobado, glabro; ovários $0,8-1,1 \times 0,7-1 \mathrm{~mm}$, globosos, glabros; estiletes unidos na base, 5-6-fidos, glabros, avermelhados. Frutos 4,3-4,9 × $5 \mathrm{~mm}$, globosos, glabros a glabrescentes; columelas inteiras. Sementes 3-3,5 × 2-2,3 mm, oblongas, tetragonais, rugosas, carúncula, séssil.

Material examinado: Mata do Xaxá, 21.I.2013, fl. e fr., F. Hurbath 451 (ALCB, SP).

Distribuição: A espécie ocorre por todo o continente americano (González Ramírez 2010) e na Índia (Gaikwad et al. 2012). No Brasil possui ampla distribuição, ocorrendo em todos os estados e biomas (Caruzo \& Cordeiro 2007; BFG 2015).

Comentários: Astraea lobata é reconhecida pelo hábito herbáceo, folhas 3-lobadas, membranáceas, margem das sépalas das flores pistiladas glandulosa. Segundo Caruzo \& Cordeiro (2007), A. lobata é a única espécie do gênero que ocorre fora da América do Sul, e apresenta "status" de ruderal. Na SGLA, é encontrada em floresta estacional decidual.

4. Cnidoscolus Pohl, Pl. Bras. Icon. Descr. 1: 56. 1827.

Arbustos, raro ervas, monóicos; indumento de tricomas urticantes, normalmente é possível visualizar o exsudato em seu interior; látex presente. Folhas alternas, limbos palmatífidos, 3-lobados, ambas as faces apresentando tricomas urticantes, estípulas ausentes; glândulas presentes na base do limbo. Inflorescências axilares ou terminais, dicásios com flores pistiladas, em geral, proximais e flores estaminadas, terminais. Flores estaminadas monoclamídeas, sépalas geralmente unidas, 5-lobadas, alvas; estames 10-20, conados formando uma coluna, ou livres. Flores pistiladas monoclamídeas, perianto semelhante ao das flores estaminadas, em geral, mais profundamente lobado; disco nectarífero inteiro; ovário trilocular; estiletes bífidos a multífidos. Fruto cápsula septicida, híspido, columela geralmente persistente. Sementes ariladas.

Gênero neotropical com ca. 50 espécies, das quais 42 ocorrem no Brasil (Webster 1994; Radcliffe-Smith 2001; BFG 2015). Caracterizase pela presença de tricomas urticantes por toda a planta, glândulas na base do limbo e flores monoclamídeas, alvas (Radcliffe-Smith 2001). Na SGLA, está representado por duas espécies. 


\section{Chave de identificação das espécies de Cnidoscolus da SGLA}

1. Ramos com tricomas aculeiformes (em forma de acúleo); estípulas largo-triangulares; filetes unidos em 2/3 do comprimento; estaminódios 2-4; ovários piriformes; fruto piriforme com linhas de deiscência alvas 4.1. C. bahianus

1'. Ramos com tricomas aciculiformes (forma de agulha); estípulas largo-ovadas; filetes unidos na base; estaminódios ausentes; ovários elipsoides; fruto obovoide com linhas de deiscência verdes.

4.2. C. urens

4.1 Cnidoscolus bahianus (Ule) Pax \& K. Hoffm., Nat. Pflanzenfam. 9c: 164. 1931.

Arbustos eretos a decumbentes, 3-4 m alt.; látex alvo; ramos não viscosos, tricomas aculeiformes. Limbos papiráceos a membranáceos, lobos semelhantes, $1,8-8,5 \times 10,2-16,5 \mathrm{~cm}$, elípticos, venação actinódroma, ápice acuminado, margem irregularmente denteada, eglandulosa, base truncada a cordada, face adaxial e face abaxial pubescentes, face abaxial verde; glândulas da base do limbo numerosas, papiliformes; pecíolos 3,5-6 cm compr.; estípulas 2,1-2,4 × 1,7-1,8 mm, largotriangulares, margem fimbriada. Inflorescências terminais, 2,5-3,5 cm compr.; raques velutinas; brácteas $2,9-3,5 \times 1,6-1,7 \mathrm{~mm}$, triangulares, margem inteira. Flores estaminadas 1,2-1,6 cm compr., sésseis; sépalas unidas em ca. $2 / 3$ do compr., perianto hipocrateriforme; lacínias 5 , $6,1-7,8 \times 4,1-4,6 \mathrm{~mm}$, elípticas a levemente oblongas, ápice obtuso, involutas, pubescentes a velutinas; estames $15-20,6,3-8,8 \mathrm{~mm}$ compr., heteromorfos, filetes unidos em ca. $2 / 3$ do compr.; coluna glabra; estaminódios 2-4. Flores pistiladas, ca. 1,2 cm compr., sésseis; sépalas 5, unidas em ca. 1/3 compr., perianto hipocrateriforme, lacínias $5,8,6-9,4 \times 3,2-3,5 \mathrm{~mm}$, oblongas, face adaxial glabra, face abaxial puberulenta; disco nectarífero 2-lobado; ovários ca. 3,8 × 1,8 mm, piriformes, tomentosos; estiletes multífidos, unidos na base, glabros. Frutos verdes com linhas de deiscência alvas, 1,9-2,2 × 1,2-1,2 cm, piriformes, hirsutos a urentes; columelas inteiras. Sementes $12 \times 6,1-7$ $\mathrm{mm}$, elipsoides.

Material examinado: Xaxá, 24.II.2012, fl. e fr., $F$. Hurbath 209 (ALCB). 22.I.2013, f1. e fr., F. Hurbath 446 (ALCB).

Distribuição: Endêmica do Brasil e registrada para as regiões Nordeste e Centro-Oeste (Melo \& Sales 2008; BFG 2015).

Comentários: Cnidoscolus bahianus é similhar a C. vitifolius (Mill.) Pohl por apresentar folhas com limbo 3-lobado, actinódromo, margem denteada, estames $15-20$ e fruto piriforme.
Contudo, diferenciam-se pelo primeiro apresentar tricomas aculeiformes nos ramos ( $v s$. aciculiformes em C. vitifolius), formato hipocrateriforme do perianto ( $v s$. campanulado) e presença de linhas de deiscência alvas nos frutos ( $v s$. linhas de deiscência verdes). Na SGLA, a espécie é encontrada em fitofisionomia de caatinga.

4.2 Cnidoscolus urens (L.) Arthur, Torreya 21: 11. 1921.

Arbustos eretos, ca. 1,5 m alt.; látex alvo; ramos não viscosos, tricomas aciculiformes. Limbos membranáceos, lobos semelhantes, 9,3-12,8 × 10,8-19,7 cm, elípticos, venação actinódroma, ápice acuminado, margem denticulada, eglandulosa, base truncada a levemente sagitada, face adaxial e abaxial glabrescente, face abaxial verde; glândulas da base do limbo numerosas, papiliformes; pecíolos 5,1-8,8 cm compr.; estípulas $0,7-1,9 \times$ 1,1-1,4 mm, largo-ovadas, margem fimbriada. Inflorescências terminais, 1,4-6,7 cm compr.; raques hirtulosas; brácteas $2,1-3 \times 0,9-1,1 \mathrm{~mm}$, ovadas a lanceoladas, margem inteira. Flores estaminadas 1,2-1,4 cm compr.; pedicelos 1,6-2,2 mm compr.; sépalas unidas em ca. $2 / 3$ compr., hipocrateriformes; lacínias 5, 3,7-4,2 × 1,5-2,3 $\mathrm{mm}$, elípticas, ápice obtuso, involutas, esparsohirtulosas; estames $10,1,7-6,5 \mathrm{~mm}$ compr., heteromorfos, verticilos $2-3$, filetes unidos na base; coluna glabra; estaminódios ausentes. Flores pistiladas apenas em botões 5-7 $\mathrm{mm}$ compr., subssésseis; sépalas 5 , unidas ca. $1 / 2$ compr., lacínias 5, 2,5-4 mm compr., face abaxial velutina; disco nectarífero inteiro; ovários ca. 1,5 × $1 \mathrm{~mm}$, elipsoides, glabro; estiletes multífidos, unidos na base, glabros. Frutos verde-escuros com linhas de deiscência verdes, 8,9-9 ×6,2-6,4 mm, obovoides, ápice truncado a emarginado, glabrescentes a urentes; columelas inteiras. Sementes 7,5-8 $\times$ 3,5-4 mm, obovoides a oblongas.

Material examinado: Caminho para o Garimpo das Ametistas, 05.XI.2013, fl. e fr., F. Hurbath 604 (ALCB). 
Distribuição: A espécie distribui-se do México à América do Sul. No Brasil ocorre nas regiões Nordeste, Sudeste e Centro-Oeste (Webster \& Burch. 1967; Melo \& Sales 2008; BFG 2015).

Comentários: Cnidoscolus urens caracterizase pelo hábito de pequeno porte, ramos com tricomas aciculiformes, e pelo fruto de ápice variando de truncado a emarginado. Diferencia-se de $C$. bahianus e $C$. vitifolius por não apresentar estaminódios ( $v s$. estaminódios presentes), apresentar ovário elipsoide (vs. ovário piriforme) e fruto obovoide ( $v s$. fruto piriforme) Na SGLA, a espécie é encontrada em mata de galeria antropizada.

5. Croton L., Sp. Pl. 2: 1004. 1753.

Ervas, subarbustos, arbustos ou árvores, monóicos, raro dioicos; indumento com tricomas estrelados, lepidotos e variações destes; látex presente. Folhas alternas, limbos inteiros, estipuladas; glândulas presentes ou ausentes na base do limbo. Inflorescências geralmente terminais, tirsos racemiformes com flores pistiladas geralmente na porção proximal da raque e estaminadas na terminal; brácteas inteiras ou partidas, com ou sem glândulas. Flores estaminadas diclamídeas, sépalas geralmente livres, 5, pétalas livres, 5 , geralmente vilosas nas margens junto à base; estames 3 a numerosos, livres, encurvados no botão. Flores pistiladas monoclamídeas, raro diclamídeas; sépalas livres ou unidas, geralmente 5 ; pétalas reduzidas, ou transformadas em glândulas, livres, ou ausentes; disco nectarífero lobado, raro inteiro; ovário trilocular; estiletes bífidos a multífidos; ovário 3-carpelar, 3-locular, um óvulo anátropo por lóculo. Fruto cápsula loculicida-septicida, indumento variado, columela geralmente persistente. Sementes com carúncula séssil.

Croton é o segundo maior gênero de Euphorbiaceae com cerca de 1.200 espécies (Govaerts et al. 2000), com distribuição pantropical, das quais 350 ocorrem no Brasil (BFG 2015). Caracteriza-se por apresentar tricomas estrelados, inflorescências em tirsos racemiformes, presença de látex, glândulas na base do limbo, estames encurvados no botão floral e estiletes partidos (Caruzo et al. 2008). Na SGLA está representado por 23 espécies.

\section{Chave de identificação das espécies de Croton da SGLA}

1. Venação actinódroma (com três ou mais nervuras primárias divergindo da base).

2. Presença de glândulas na base do limbo.

3. Ápice do limbo apiculado a aristado; glândulas capitadas; pecíolos 2,1-5,2 mm compr.; estiletes livres 5.15. C. mucronifolius

3'. Ápice do limbo agudo; glândulas pateliformes ou discoides; pecíolos com 10-11,3 mm compr.; estiletes unidos na base.

4. Inflorescências 1,5-3 cm compr.; pétalas das flores estaminadas oblongas

5.1. C. adamantinus

4'. Inflorescências $6,2-15,6 \mathrm{~cm}$ compr.; pétalas das flores estaminadas obovadas a espatuladas.

5. Limbos cordiformes, face adaxial escabra; glândulas pateliformes; estípulas $3-5 \times$ 0,5-0,7 mm; estiletes 4-6-fidos. 5.19. C. triangularis

5'. Limbos ovados, face adaxial glabrescente; glândulas discoides; estípulas 0,5-0,8 $\times 0,3-0,4 \mathrm{~mm}$; estiletes 2 -fidos 5.23. C. virgultosus

2'. Ausência de glândulas na base do limbo.

6. Látex alaranjado; glândulas presente na margem do limbo; flores estaminadas 10,4-11,5 mm compr.; 65 estames; pétalas das flores pistiladas transformadas em glândulas.

6'. Látex translúcido; glândulas ausentes na margem do limbo; flores estaminadas 5,1-6,8 mm compr.; 11-13 estames; pétalas da flor pistilada ausentes.

7. Base dos limbos cordadas; estípulas ovadas; inflorescências $5,5-7,8 \mathrm{~cm}$ compr.; brácteas ovadas a triangulares 5.22. C. urticifolius

7'. Base dos limbos atenuada a arredondada; estípulas lineares a estreito-lanceoladas; inflorescências 1,3-3 cm compr.; brácteas pinatífidas 5.21. C. triqueter 
1'. Venação eucamptódroma (nervuras secundárias curvam-se para o ápice mas não se tocam), ou broquidódroma (nervuras secundárias curvam-se e se tocam formando arcos), ou cladódroma (nervuras secundárias ramificam-se, mas não alcançam a margem).

8. Margem dos limbos inteira.

9. Face abaxial dos limbos cinérea a argêntea, com indumento lepidoto e tricomas estreladolepidotos.

10. Face adaxial dos limbos lepidota; glândulas presentes na base do limbo; estiletes 2-fidos 5.12. C. imbricatus

10’. Face adaxial dos limbos pubescente a estrigosa; glândulas ausentes na base do limbo; estiletes 6-8-fidos.

11. Estípulas lanceoladas, 8,5-10 mm compr.; flores estaminadas 9,5-12 mm compr.;16-18 estames... 5.2. C. argyrophyllus

11'. Estípulas lineares, 0,4-1 mm de compr.; flores estaminadas 3,8-5,7 mm compr.; 11 estames 5.20. C. tricolor

9'. Face abaxial dos limbos creme a amarelada, glauca, ou verde, com indumento pubescente, flocoso, lanoso ou tomentoso e tricomas estrelados ou simples.

12. Folhas cladódromas; glândulas ausentes na base do limbo.

13. Limbos ovados a cordiformes; base cordada; pecíolos $1,1-5 \mathrm{~cm}$ compr.; estípulas 4-7 mm compr., lineares a falciformes; estiletes 8-10-fidos

5.13. C. jacobinensis

13'. Limbos elípticos; base aguda a arredondada; pecíolos 3,8-7,3 mm compr.; estípulas $1,5-1,8 \mathrm{~mm}$ compr., estreito-triangulares a lanceoladas; estiletes 2 -fidos....

5.17. C. pedicellatus

12'. Folhas eucamptódromas a broquidódromas; glândulas presentes na base do limbo.

14. Glândulas na base do limbo sésseis, capitadas; estípulas transformadas em glândulas.

15. Face adaxial dos limbos e face abaxial das sépalas das flores estaminadas tomentosas ; 13-16 estames; estiletes livres 5.4. C. campestris

15'. Face adaxial dos limbos e face abaxial das sépalas das flores estaminadas esparso-pubescentes a glabrescentes; 16-23 estames; estiletes unidos na base

5.10. C. heliotropiifolius

14'. Glândulas na base do limbo estipitadas, pateliformes ou discoides; estípulas ovadas, ou triangulares a lanceoladas.

16. Glândulas na margem do limbo ausentes; face adaxial glabrescente; pecíolos 2,9-4 cm compr.; inflorescências 15-31,7 cm compr.; 15-16 estames

5.5. C. echioides

16'. Glândulas na margem dos limbos presentes; face adaxial estrigosa; pecíolos 3,5-6,9 mm compr.; inflorescências 6,2-7,9 cm compr.; 11 estames

5.3. C. betaceus

8'. Margem dos limbos crenada, denteada, ou duplo-denteada, serrilhada a serreada, ou duplo serreada.

17. Glândulas presentes na base do limbo; estiletes 2-fidos.

18. Ervas; ápice dos limbos agudo; glândulas ausentes nas margens dos limbos; sépalas das

flores pistiladas oblanceoladas

5.11. C. hirtus

18'. Arbustos; ápice dos limbos atenuado a acuminado, ou mucronulado; glândulas presentes nas margens dos limbos; sépalas das flores pistiladas ovadas a lanceoladas.

19. Limbos ovados; ápice atenuado a acuminado; margem das estípulas inteiras; brácteas com margem eglandulosa; flores pistiladas pediceladas; ovários hirsutopubescentes. 5.9. C. grewioides

19'. Limbos largo-ovados a orbiculares; ápice mucronulado; margem das estípulas fimbriado-glandulosa; brácteas com glândulas na margem; flores pistiladas sésseis; ovários tomentosos. 5.7. C. glandulosobracteatus

17'. Glândulas ausentes na base do limbo; estiletes 3-5-fidos. 
20. Margem dos limbos com glândulas; ovários hirsutos ou tomentosos; frutos glabrescentes a tomentosos.

21. Arbustos ca. 0,1-0,2 m alt.; limbos 0,7-1 × 0,57-0,64 cm, elípticos a largo-elípticos, face adaxial glabra; estípulas laciniadas; flores pistiladas verde-amareladas; ovários hirsutos; frutos glabrescentes

5.16. C. nummularius

21'. Arbustos ca. 1-1,2 m alt.; limbos 2,3-4,9 ×5-2 cm, estreito-elípticos a lanceolados, face adaxial pubescente; estípulas lineares a lanceoladas; flores pistiladas ferrugíneas; ovários tomentosos; frutos tomentosos.....

5.6. C. eremophilus

20'. Margem dos limbos eglandulosa; ovários pubescentes; frutos glabros.

22. Ramos viscosos; estípulas ovadas a lanceoladas, ou lineares; raque da inflorescência glabrescentes; pedicelos das flores pistiladas 5-13 mm compr.; disco nectarífero 5-lobado; estiletes 3-fidos......

5.8. C. glutinosus

22'. Ramos não viscosos; estípulas palmatífidas a pinatífidas; raque da inflorescência tomentosa a pubescente; pedicelos das flores pistiladas 0,6-1,1 mm compr.; disco nectarífero inteiro; estiletes 4-5-fidos. 5.18. C. rudolphianus

5.1 Croton adamantinus Müll. Arg., Fl. bras., 11(2): 115. 1873.

Arbustos eretos, ca. 1,5 m alt., monoicos; látex translúcido; ramos não viscosos, tricomas estrelados sésseis a estipitados. Limbos papiráceos, 4,5-6,1 × 2,9-3,6 cm, ovados a cordiformes, venação actinódroma, ápice agudo, margem crenada a duplo serrilhada com glândulas estipitadas, base cordada, face adaxial glabrescente a esparso-pubescente, face abaxial pubescente, ambas com tricomas estrelados, face abaxial levemente glauca; glândulas presentes na base do limbo, 2-4, estipitadas, pateliformes; pecíolos $1-2,8 \mathrm{~cm}$ compr.; estípulas $2,1-6,4 \times 0,3-0,8$ $\mathrm{mm}$, lanceoladas, margem inteira. Inflorescências 1,5-3 cm compr., raques pubescentes ou hirsutas; brácteas 1,3-1,5 mm compr., lineares, margem inteira. Flores estaminadas branco-esverdeadas, 5,5-6,6 mm compr.; pedicelos 2-3 mm compr.; sépalas $1-2,5 \times 1-1,2 \mathrm{~mm}$, elípticas a ovadas, face abaxial pubescente; pétalas 5, 2-2,5 × 1-1,3 $\mathrm{mm}$, oblongas; estames 10-11, 3,2-4 mm compr. Flores pistiladas branco-esverdeadas, 4,6-5,5 $\mathrm{mm}$ compr., pedicelos $2-3 \mathrm{~mm}$ compr.; sépalas $5-7$, desiguais $1,8-2,7 \times 0,2-0,5 \mathrm{~mm}$, lineares a lanceoladas, livres, margem eglandulosa, face abaxial pubescente; disco nectarífero 5-7-lobado, glabro; pétalas ausentes; ovários ca. 1,4×1,4 mm, globosos, tomentosos a hirsutos; estiletes unidos na base, 2-fidos, glabrescentes. Frutos, columelas e sementes não observados.

Material examinado: Estrada para Caetité, 03.XI.2006, fl. e fr., R.F. Souza-Silva 222 (HUEFS). Estrada $5 \mathrm{~km}$ de Licínio de Almeida para Urandi, 09.XII.2009, fl. e fr., M.L. Guedes 1669 (ALCB).

Distribuição: Endêmica do Brasil, ocorre em toda a região Nordeste e porção norte da região
Sudeste, no Estado de Minas Gerais, estando restrita ao bioma Caatinga (Carneiro-Torres 2009; BFG 2015).

Comentários: Croton adamantinus assemelha-se a $C$. Triangularis por apresentar folhas com venação palmatinérvias, base do limbo cordada, presença de glândulas estipitadas na margem, e face abaxial glauca a levemente glauca. Diferencia-se por apresentar inflorescência duas vezes menor, sépalas da flor pistilada em numero de 7, lanceoladas a lineares (vs. 5 sépalas ovadas), disco nectarífero 7-lobado (vs. 5-lobado) e estilete 2-fidos (vs. 4-6-fido). Ver também comentários em C. virgultosus Müll. Arg. Na SGLA, é encontrada em fitofisionomia de cerrado.

5.2 Croton argyrophyllus Klotzsch ex Baill., Adansonia 4: 291. 1864.

Arbustos eretos, ca. 1,3 m alt., monoicos; látex translúcido; ramos não viscosos, tricomas estrelados-lepidotos porréticos. Limbos papiráceos, $5,7-8 \times 2,2-3,3 \mathrm{~cm}$, elípticos a lanceolados, venação cladódroma, ápice mucronado, margem inteira, eglandulosa, base arredondada a retusa, face adaxial estrigosa, com tricomas estrelados, face abaxial lepidota, com tricomas estreladolepidotos, face abaxial argêntea; glândulas ausentes na base do limbo; pecíolos 1,1-1,9 cm compr.; estípulas 8,5-10 × 2,5-3 mm, lanceoladas, margem inteira. Inflorescências 3,3-4,7 cm compr., raques lepidotas; brácteas 1,8-2,4 ×0,3 mm, lineares, margem inteira. Flores estaminadas cremes, 9,5-12 $\mathrm{mm}$ compr.; pedicelos 4,5-6 mm compr.; sépalas 3,6-4,2 × 2,2-3 mm, ovadas, face abaxial lepidota; pétalas 5, 3,5-4,1 × 0,8-1 mm, oblongas; estames 16-18, 5-6 mm compr. Flores pistiladas cremes, ca. $7 \mathrm{~mm}$ compr., pedicelos 1-2 mm compr.; sépalas 
4-5, levemente desiguais, 3,8-4 × 1,8-2,5 mm, oblongas a levemente panduradas, unidas na porção basal, margem eglandulosa, face abaxial lepidota; disco nectarífero inteiro ou 5-lobados, lepidotos; pétalas ausentes; ovários ca. $4 \times 4 \mathrm{~mm}$, globosos com projeções no ápice, lepidotos; estiletes unidos na base, $6-8$-fidos, pubescentes. Frutos $6 \times 5 \mathrm{~mm}$, lepidotos, columelas inteiras. Sementes 4,5 × 2,5-3 $\mathrm{mm}$, elipsoides a ovoides.

Material examinado: Trilha Xaxá-Cachoeirão, 23.I.2013, fl. e fr., F. Hurbath 462 (ALCB).

Distribuição: A espécie ocorre na Venezuela e Brasil, neste último, apenas nas regiões Nordeste e Norte (Gillespie 1993; Carneiro-Torres 2009; BFG 2015).

Comentários: Croton argyrophyllus assemelha-se a Croton tricolor pela presença de tricomas estrelados-lepidotos que confere à face abaxial das folhas, inflorescência, e frutos uma cor argêntea. Diferencia-se por apresentar estipulas lanceoladas, 8-10 $\mathrm{mm}$ compr. (vs. estípulas lineares, até $1 \mathrm{~mm}$ compr.), flores estaminadas maiores, maior que $9 \mathrm{~mm}$ compr. (vs. até $2,5 \mathrm{~mm}$ compr.), e 16-18 estames, (vs. 11 estames). $\mathrm{Na}$ SGLA, a espécie é encontrada em fitofisionomia de cerrado.

5.3 Croton betaceus Baill., Adansonia 4: 341. 1864.

Arbustos eretos, ca. 1-1,5 m alt., monoicos; látex translúcido; ramos não viscosos, tricomas estrelados porreticos. Limbos membranáceos a papiráceos, 4,9-8,6 × 2,4-3,6 cm, elípticos a ovados, venação eucamptódroma a broquidódroma, ápice agudo a acuminado, margem inteira com glândulas sésseis, base arredondada, face adaxial estrigosa, com tricomas tectores, face abaxial pubescente, com tricomas estrelados, verde; glândulas presentes na base do limbo, 2, estipitadas, discoides; pecíolos 3,5-6,9 mm compr.; estípulas $1,2-2,2 \times 0,8 \mathrm{~mm}$, triangulares a lanceoladas, margem inteira. Inflorescências $6,2-7,9 \mathrm{~cm}$ compr.; raque pubescente ou hirsuta; brácteas $1,3-2 \times$ $0,5-1 \mathrm{~mm}$, triangulares, margem inteira. Flores estaminadas esverdeadas, 2,7-3,4 $\mathrm{mm}$ compr., pedicelos $0,8-1,3 \mathrm{~mm}$ compr.; sépalas 1,7-2,1 $\times$ $1,3-1,4 \mathrm{~mm}$, ovadas, face abaxial glabra; pétalas $5,2,2-2,4 \times 0,5-0,6 \mathrm{~mm}$, espatuladas; estames 11, 2-2,7 mm compr.; receptáculo piloso. Flores pistiladas esverdeadas, 3,5-4 mm compr., sésseis; sépalas 5 , levemente desiguais, $1,8-2,4 \times 0,7-1$ $\mathrm{mm}$, ovadas, unidas na porção basal, face abaxial glabra; disco nectarífero 5-lobado, glabro; pétalas
5, transformadas em glândulas; ovários 1,2-1,4 $\times 1,2-1,4 \mathrm{~mm}$, transversalmente elipsoides a globosos, tomentosos a hirsutos; estiletes unidos na base, 2-fidos, glabrescentes. Frutos, columelas e sementes não observados.

Material examinado: Estrada $7 \mathrm{~km}$ de Licínio de Almeida para Urandi, 09.XII.2009, fl., M.L. Guedes 16716 (ALCB).

Distribuição: Endêmica da America do Sul, e no Brasil ocorre nas regiões Norte, Nordeste, Sudeste e Centro-Oeste (Carneiro-Torres 2009; BFG 2015).

Comentários: Croton betaceus pode ser facilmente reconhecida por apresentar folhas opostas no ápice dos ramos, com margens inteiras, com glândulas sésseis e face adaxial apresentando tricomas tectores. Segundo Carneiro-Torres (2009), a espécie é encontrada em bordas de florestas ombrófilas. Na SGLA, a espécie é encontrada em ecótono entre caatinga e cerrado.

5.4 Croton campestris A. St.-Hil., Pl. Usuel. Bras. t. 60.1827.

Arbustos eretos, ca. 0,7-1 m alt., monoicos; látex translúcido; ramos não viscosos, tricomas estrelados estipitados porréticos. Limbos papiráceos a cartáceos, 1,7-7,5 × 1-2,8 cm, estreito-elípticos a elípticos, ou obovados, venação eucamptódroma a broquidódroma, ápice levemente agudo a arredondado, margem inteira com glândulas sésséis, ou eglandulosa, base arredondada a truncada, face adaxial e face abaxial tomentosas, ambas com tricomas estrelados, face abaxial creme; glândulas presentes na base do limbo, $2-5$, sésseis, capitadas; pecíolos 3,5-13,6 mm compr., estípulas transformadas em glândulas. Inflorescências 1,5-12,3 cm compr.; raque tomentosa; brácteas $1,2-2 \times 0,4-0,5 \mathrm{~mm}$, lanceoladas, margem inteira a levemente erosa. Flores estaminadas cremes e ferrugíneas, 2-5,1 mm compr., pedicelos $0,6-1,8$ mm compr.; sépalas 1,7-2,5 ×0,7-1,5 mm, elípticas a levemente ovadas, face abaxial tomentosa; pétalas $5,1,7-2,1 \times 0,6-1 \mathrm{~mm}$, elípticas a obovadas; estames 13-16, 2,5-3,2 mm compr.; receptáculo piloso. Flores pistiladas cremes a ferrugíneas, 5-6,4 $\mathrm{mm}$ compr., séssil a subséssil; sépalas 5 , levemente desiguais, 2,2-3 × 1-1,5 mm, lanceoladas, unidas na porção basal, face abaxial tomentosa; disco nectarífero 5-lobado, glabro; pétalas ausentes; ovários 1,6-1,9 × 2-2,3 mm, globosos, tomentosos; estiletes livres, 2-fidos, glabrescentes. Frutos 4,3-5,3 $\times 3,5-5,9 \mathrm{~mm}$, tomentosos, columelas com ápice tripartido. Sementes 3-4,1 × 2-2,9 mm, elipsoides. 
Material examinado: Espinhaço, 25.II.2012, fl. e fr., F. Hurbath 245 (ALCB). Trilha para o Cachoeirão, 26.II.2012, fr., F. Hurbath 259 (ALCB). 26.II.2012, fl. e fr., F.S. Afonso 155 (ALCB).

Distribuição: Endêmica da América do Sul e no Brasil ocorre nas regiões Norte, Nordeste, Sudeste e Centro-Oeste (Carneiro-Torres 2009; BFG 2015).

Comentários: A espécie exibe grande variação morfológica, principalmente com relação ao tamanho das folhas. Assemelha-se a Croton heliotropiifolius Kunth em seu aspecto geral com indumento tomentoso por toda a planta, creme, com glândulas sésseis na base do limbo. Diferencia-se por apresentar face adaxial do limbo e face abaxial das sépalas das flores estaminadas tomentosas ( $v S$. esparso-pubescente a glabrescente), até 13-16 estames (vs. 16-23) e estiletes livres (vs. unidos na base). Na SGLA, é encontrada em fitofisionomias de cerrado, campos rupestres e cerrado antropizado.

5.5 Croton echioides Baill., Adansonia 4: 334. 1862.

Subarbustos eretos, ca. 0,5 m alt., monoicos; látex translúcido; ramos não viscosos, tricomas estrelados curto-estipitados porréticos. Limbos membranáceos a papiráceos, 4-10,9 × 1,7$5,3 \mathrm{~cm}$, elípticos, venação eucamptódroma a broquidódroma; ápice acuminado, margem inteira, eglandulosa, base arredondada a truncada, face adaxial glabrescente, face abaxial esparsopubescente, ambas com tricomas estrelados, face abaxial verde; glândulas presentes na base do limbo, 2, longo-estipitadas, pateliformes; pecíolos 2,9-4 cm compr.; estípulas $0,7-1,3 \times 0,5 \mathrm{~mm}$, ovadas, margem inteira. Inflorescências 15-31,7 cm compr., pubescentes; brácteas 1,3-1,5 × 0,4-0,7 mm, ovadas-cirrosas a aristadas, margem inteira. Flores estaminadas castanho-amareladas, 2,5-3,5 mm compr., pedicelos 1,6-2 mm compr.; sépalas 2,12,6 × 1-1,2 mm, ovadas, face abaxial glabrescente; pétalas $5,2,2-3 \times 0,8-1,1 \mathrm{~mm}$, espatuladas; estames 15-16, 3-3,5 mm compr.; receptáculo piloso. Flores pistiladas amareladas, 2,8-3,6 mm compr., subsésseis; sépalas 5, iguais, 1,3-2 × 0,5-2 $\mathrm{mm}$, lanceoladas, livres, margem eglandulosa, face abaxial glabrescente; disco nectarífero 5-lobado, glabro; pétalas ausentes; ovários 1,5-2,1 × 1,5-2,5 $\mathrm{mm}$, globosos, pubescentes; estiletes unidos na base, 2-fidos, glabrescentes. Frutos, columelas e sementes não vistos.

Material examinado: Mata do Xaxá, 22.I.2013, fr., F. Hurbath 452 (ALCB). Estrada para Urandi, $7 \mathrm{~km}$ de
Licínio de Almeida, 9.XII.2009, fl. e fr., E. Melo 7369 (ALCB, HUEFS).

Distribuição: Endêmica do bioma Caatinga, a espécie ocorre nas regiões Norte, Nordeste, Sudeste e Centro-Oeste (Carneiro-Torres 2009; BFG 2015).

Comentários: Croton echioides é reconhecida por apresentar folhas opostas no ápice dos ramos, margem inteira sem glândulas, inflorescências longas e laxas, flores pistiladas sésseis e estiletes o dobro do tamanho do ovário. Na SGLA, a espécie é encontrada em floresta estacional decidual.

5.6 Croton eremophilus Müll. Arg., Fl. bras. 11(2): 184. 1874.

Arbustos eretos, ca. 1-1,2 m alt., monoicos; látex translúcido; ramos não viscosos, tricomas estrelados estipitados porréticos. Limbos papiráceos, 2,3-4,9 × 5-2 cm, estreito-elípticos a lanceolados, venação eucamptódroma; ápice agudo, margem crenada com glândulas sésseis e alvas, base arredondada a levemente retusa, face adaxial pubescente, face abaxial tomentosa, ambas com tricomas estrelados, face abaxial creme a ferrugínea; glândulas ausentes na base do limbo; pecíolos 3,2-8,1 mm compr., estípulas $0,5-2 \times 0,2-0,5 \mathrm{~mm}$, lineares a lanceoladas, margem glandulosa. Inflorescências 6,4-25 mm compr.; raque tomentosa; brácteas $2-5 \times 1 \mathrm{~mm}$, lineares a lanceoladas, margem com glândulas. Flores estaminadas cremes e ferrugíneas, 4,2-6,5 mm compr., pedicelos 1-2 mm compr.; sépalas 5, 2-3 $\times 0,8-1,1 \mathrm{~mm}$, elípticas a levemente ovadas, face abaxial tomentosa; pétalas $5,2-2,5 \times 1-1,4$ $\mathrm{mm}$, elípticas a levemente obovadas; estames 10-11, 3-4 mm compr.; receptáculo piloso. Flores pistiladas ferrugíneas, 3-5 mm compr., pedicelos 0,5-2 mm compr.; sépalas 5, levemente desiguais, 3-4,8 $\times 1-2 \mathrm{~mm}$, triangulares ou lanceoladas, unidas na porção basal, margem com glândulas, face abaxial tomentosa, disco nectarífero 5-lobado, glabro; pétalas ausentes; ovários ca. 1,5 $\times 2 \mathrm{~mm}$, transversalmente elipsoides a globosos, tomentosos; estiletes unidos na base, 4-6-fidos, glabrescentes. Frutos 4-6,1 × 4-5 mm, tomentosos, columelas inteiras. Sementes 3-4 × 2,5-3 mm; largo-elipsoides.

Material examinado: Lameirão, 11.V.2012, fl. e fr., F. Hurbath 289 (ALCB). Pedra Preta, 21.I.2013, fl., F. Hurbath 424 (ALCB). Cascarrento, 22.I.2013, fl., F. Hurbath 442 (ALCB).

Distribuição: A espécie é restrita à Cadeia do Espinhaço nos Estados da Bahia e Minas Gerais (Carneiro-Torres 2009; BFG 2015). 
Comentários: Croton eremophilus aproximase morfologicamente a C. atrorufus Müll. Arg., por apresentar glândulas sésseis e alvas nas margens do limbo, face abaxial do limbo, inflorescência e flores tomentosas, ferrugíneas, e sépalas das flores pistiladas com glândulas na margem. Diferencia-se por apresentar estiletes 4-6-fidos ( $v s$. 2-fidos). $\mathrm{Na}$ SGLA, a espécie é encontrada em fitofisionomia de cerrado, cerrado antropizado, cerrado de altitude e ecótonos entre caatinga e cerrado.

5.7 Croton glandulosobracteatus Carn. -Torres \& Cordeiro, Brittonia 63(1): 126-128. 2011.

Arbustos eretos, ca. 0,6-1 m alt., monoicos; látex translúcido; ramos não viscosos, tricomas estrelados estipitados. Limbos papiráceos a cartáceos, 1,6-4,1 × 1,5-4,2 cm, largo-ovados a orbiculares, venação cladódroma; ápice mucronulado, margem denteada com glândulas estipitadas, base cordada, face adaxial e face abaxial tomentosas, ambas com tricomas estrelados, face abaxial verde-cinérea; glândulas presentes na base do limbo, 2, estipitadas, pateliformes; pecíolos $2,2-8,8 \mathrm{~mm}$ compr.; estípulas $0,8-2 \times 0,7-1,4$ $\mathrm{mm}$, triangulares, margem fimbriado-glandulosa. Inflorescências 9,8-15 $\mathrm{mm}$ compr.; raque tomentosa; brácteas $2-3,7 \times 0,3-1 \mathrm{~mm}$, estreitolanceoladas, margem fimbriado-glandulosa. Flores estaminadas cremes e ferrugíneas, $5-8,4 \mathrm{~mm}$ compr., pedicelos 1,3-2,8 mm compr.; sépalas, $2,1-3,6 \times 1,1-2,2 \mathrm{~mm}$, levemente elípticas a ovadas, face abaxial tomentosa; pétalas $5,3-3,4 \times$ 1-1,6 mm, estreito-obovadas a oblanceoladas, ou espatuladas a levemente unguiculadas; estames 11, 4-5,7 mm compr.; receptáculo piloso. Flores pistiladas ferrugíneas, $6,1-7 \mathrm{~mm}$ compr., sésseis; sépalas 5 , desiguais, $3,1-5 \times 0,8-2 \mathrm{~mm}$, ovadas a lanceoladas, unidas na porção basal, face abaxial tomentosa; disco nectarífero 5-lobado, glabro; pétalas ausentes; ovários 2-2,2 × 2-2,2 mm, globosos, tomentosos; estiletes unidos na base, 2-fidos, glabrescentes. Frutos 3,9-5 × 3,2-4,3 mm, tomentosos, columelas inteiras. Sementes $3,1-4,1$ $\times 2,3-2,4 \mathrm{~mm}$, elipsoides.

Material examinado: Cascarrento, 10.V.2012, fl. e fr., F. Hurbath 277 (ALCB). 28.X.2012, fl., F. Hurbath 403 (ALCB). 22.I.2013, fl., F. Hurbath 441 (ALCB).

Distribuição: Endêmica dos Campos Rupestres da Cadeia do Espinhaço (BA, MG) (Carneiro-Torres et al. 2011; BFG 2015).

Comentários: Croton glandulosobracteatus pode ser reconhecida por apresentar folhas com limbo largo-ovado a largo-orbicular, estípulas e brácteas com glândulas na margem e flores pistiladas sésseis a subsésseis. Em sua descrição original, $C$. glandulosobracteatus não apresenta glândulas na base da folha, diferindo dos indivíduos coletados na SGLA, contudo, os demais caracteres diagnósticos como margem das folhas com glândulas sésseis, margens das estípulas mais curtamente fimbriadoglandulosa, e flores pistiladas sésseis a subsésseis correspondem ao protólogo da espécie. Na SGLA, a espécie é encontrada em uma única localidade e em fitofisionomia de cerrado de altitude.

5.8 Croton glutinosus Müll. Arg., Fl. bras. 11(2): 200. 1874.

Fig. 2a-g

Arbustos eretos, ca. 0,7-1,1 m alt., monoicos; látex translúcido; ramos viscosos, tricomas estrelados sésseis. Limbos papiráceos a cartáceos, $1,3-7,2 \times 0,8-4,3 \mathrm{~cm}$, ovados a lanceolados e conduplicados, venação cladódroma, ápice agudo a acuminado, margem crenada a serrilhada, eglandulosa, base arredondada a retusa, face adaxial glabra, face abaxial glabrescente, com tricomas estrelados, verde; glândulas ausentes na base do limbo; pecíolos 7,5-13,6 mm compr., estípulas $0,5-2,4 \times 0,5-1,7 \mathrm{~mm}$, ovadas a lanceoladas, ou lineares, margem frimbriadoglandulosa. Inflorescências 20-75 mm compr.; raque glabrescente; brácteas 2,4-4 × 0,5-0,6 mm, lineares a estreito-lanceoladas, ou triangulares, margem inteira, pode apresentar glândulas na porção inferior. Flores estaminadas verdes e cremes, 5,7-8,4 mm compr., pedicelos 1,5-6,1 $\mathrm{mm}$ compr.; sépalas 2,5-3,5 × 1-1,5 mm, elípticas a ovadas, face abaxial pubescente; pétalas 5, 2,5-3,4 $\times 1,5-2 \mathrm{~mm}$, obovadas; estames 11-12, 2,5-4 mm compr.; receptáculo piloso. Flores pistiladas verdes, 3-6,6 mm compr., pedicelos 5-13 mm compr.; sépalas 5 , iguais a levemente desiguais, $4-7 \times$ 1-2 mm, lanceoladas, livres, margem laciniadas com glândulas, face abaxial glabrescente; disco nectarífero 5-lobado, glabro; pétalas ausentes; ovários 2-2,5 × 1,8-2 mm, globosos, pubescentes; estiletes unidos na base, 3 -fidos, glabros. Frutos $5,7-7,3 \times 6-7,5 \mathrm{~mm}$, glabrescentes, columelas inteiras. Sementes 4-4,5 × 3-3,1 mm, elipsoides. Material examinado: Cascarrento, 11.V.2012, fl. e fr., $F$. Hurbath 284 (ALCB). Saco da Onça, próximo ao limite municipal, 21.VII.2012, fl. e fr., N. Roque 3694 (ALCB). Trilha após subida do Cachoeirão, 26.II.2013, fl. e fr., $F$. Hurbath 263 (ALCB).

Distribuição: Endêmica da Cadeia do Espinhaço (BA, MG) (Carneiro-Torres 2009; BFG 2015). 


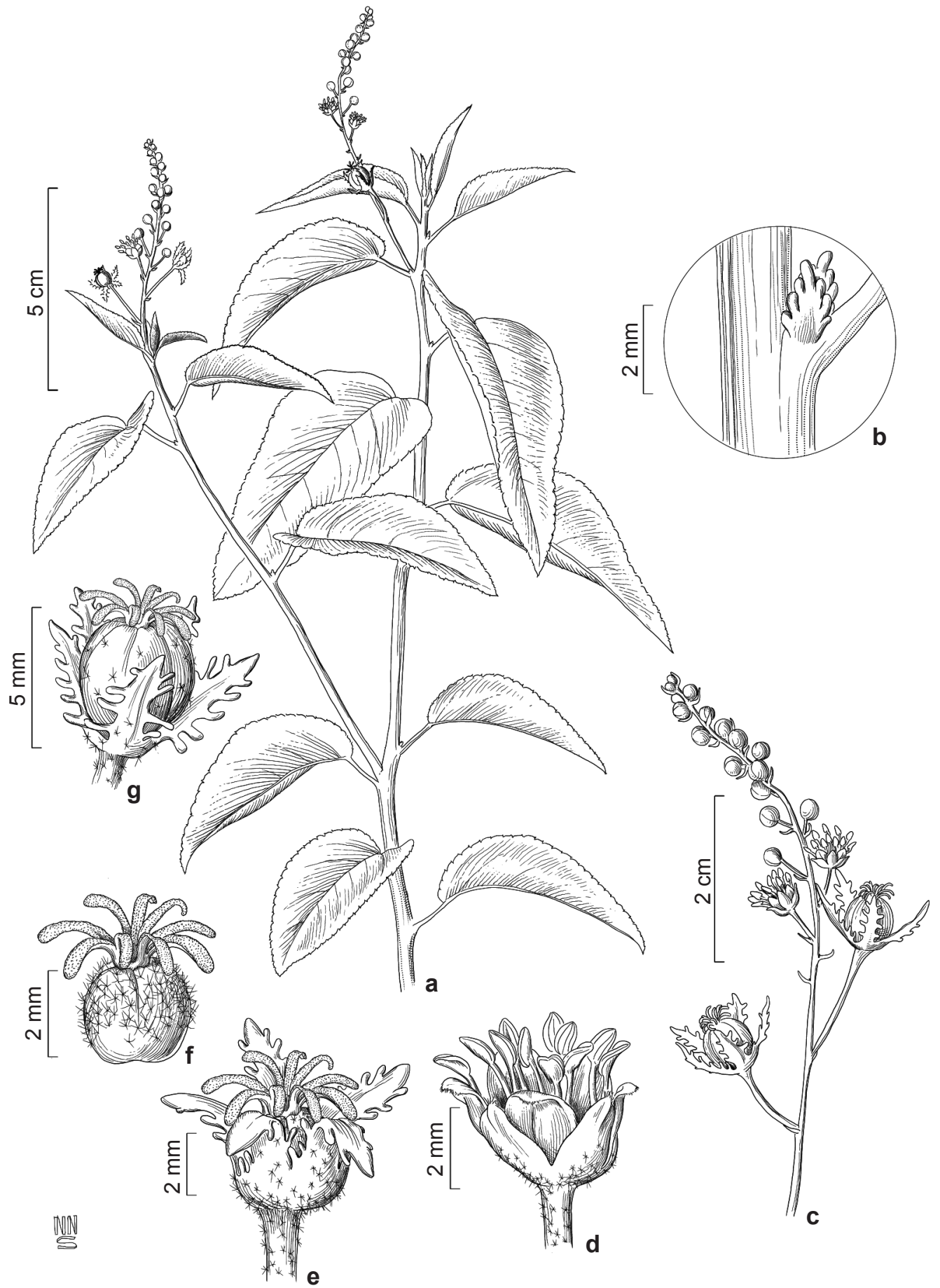

Figura 2 - a-g. Croton glutinosus - a. ramo fértil; b. detalhe das estípulas; c. inflorescência; d. flor estaminada; e. flor pistilada; f. ovário e estiletes; g. fruto. (a-g. F. Hurbath 263).

Figure 2 - a-g. Croton glutinosus - a. fertile branch; b. stipules in detail; c. inflorescence; d. staminate flower; e. pistillate flower; f. ovary and styles; g. fruit (a-g. F. Hurbath 263). 
Comentários: Croton glutinosus apresenta semelhança com C. betulaster Müll. Arg. por apresentar ramos viscosos, margem do limbo sem glândulas e base arredondada a retusa. Diferenciase por apresentar flores longo-pediceladas (5-13 $\mathrm{mm}$ compr.) ( $v s$. flores pistiladas com pedicelos de até $5 \mathrm{~mm}$ compr. em C. betulaster). C. glutinosus apresenta, também, limbo conspicuamente conduplicado, facilitando a identificação do material herborizado pelas folhas se apresentarem dobradas, o que não é evidenciado em $C$. betulaster. Na SGLA, a espécie é encontrada sempre em campos rupestres ou em cerrado de altitude.

5.9 Croton grewioides Baill., Adansonia 4: 365 . 1864.

Arbustos eretos, ca. 1,2-2 m alt., monoicos; látex translúcido; ramos não viscosos, tricomas estrelados porréticos, multirradiados a dendríticos. Limbos membranáceos a papiráceos, 2,4-6,7 × 1,1-2,9 mm, ovados, venação cladódroma, ápice atenuado a acuminado, margem duplo-serreada com glândulas estipitadas, base arredonda a levemente retusa, face adaxial esparso-pubescente a pubescente, face abaxial pubescente, ambas com tricomas estrelados, face abaxial verde-amarelada a levemente glauca; glândulas presentes na base do limbo, 2, curto-estipitadas a estipitadas, pateliformes; pecíolos 4-13,4 mm comrp.; estípulas $0,4-0,8 \times 0,1-0,3 \mathrm{~mm}$, lineares a estreitolanceoladas, margem inteira. Inflorescências 1,3$5,2 \mathrm{~cm}$ compr.; raque hirsuto-pubescente; brácteas $0,5-0,7 \times 0,2 \mathrm{~mm}$, lineares a lanceoladas, margem inteira. Flores estaminadas verde-ferrugíneas, $2,8-3,5 \mathrm{~mm}$, pedicelos $0,8-1,3 \mathrm{~mm}$, sépalas $1,3-1,8$ $\times 1 \mathrm{~mm}$, obovadas, face abaxial pubescente; pétalas $5,1,4-2 \times 1-1,4 \mathrm{~mm}$, obovadas; estames 11, 2-3,4 $\mathrm{mm}$, receptáculo piloso. Flores pistiladas verdeferrugíneas, $2-2,2 \times 1,5-2 \mathrm{~mm}$, pedicelos 1,8-2,5 $\mathrm{mm}$ compr.; sépalas 5 , iguais, $1,1-2 \times 0,3-0,6 \mathrm{~mm}$, lanceoladas, livres, face abaxial pubescente; disco nectarífero 5-partido, papiloso a glabrescente; pétalas 5, lineares ou ausentes; ovários 1,5-2 $\times$ 1,3-2 mm, globosos, hirsuto-pubescentes; estiletes unidos na base, 2-fidos, glabrescentes. Frutos $4 \times 4$ $\mathrm{mm}$, globosos, pubescentes, columelas e sementes não observadas.

Material examinado: Saco da Onça, próximo ao limite municipal, 21.VII.2012, fr., N. Roque 3694 (ALCB). Xaxá, 22.I.2013, fl., F. Hurbath 447 (ALCB). Trilha XaxáCachoeirão, 23.I.2013, fl. e fr., F. Hurbath 463 (ALCB).

Distribuição: A espécie é endêmica da Caatinga (Carneiro-Torres 2009; BFG 2015).
Comentários: Croton grewioides pode ser facilmente reconhecida por apresentar glândulas estipitadas na margem do limbo e na base do limbo, e pelo limbo ovado com ápice atenuado a acuminado. Apresenta aroma de alecrim, mesmo quando herborizado, sentido ao macerar suas folhas. Segundo Carneiro-Torres (2009) e Silva et al. (2009), os indivíduos também podem apresentar aroma de canela, contudo, os indivíduos coletados na SGLA não apresentaram este odor. Na SGLA, a espécie é encontrada em fitofisionomia de caatinga, caatinga sobre afloramento rochoso e cerrado.

5.10 Croton heliotropiifolius Kunth, Nov. Gen. Sp. 2: 83. 1817.

Arbustos eretos, 1-1,7 m alt., monoicos; látex translúcido; ramos não viscosos, tricomas estrelados estipitados ou curto-estipitados porréticos. Limbos papiráceos a cartáceos, ou membranáceos, 4-10 × 1-3,6 cm, estreitoelípticos a lanceolados, ou oblongos, venação eucamptódroma a broquidódroma, ápice agudo, ou arredondado a mucronulado, margem inteira a levemente serrilhada, eglandulosa, base arredondada a obtusa, levemente retusa, face adaxial glabrescente, face abaxial pubescente a flocosa, ambas com tricomas estrelados, face abaxial amarelada a levemente glauca; glândulas presentes na base do limbo, 2, sésseis, capitadas; pecíolos 5-28 mm compr., estípulas transformadas em glândulas. Inflorescências 2,5-9,3 cm compr.; raque tomentosa, ou hirsuto-pubescente a flocosa; brácteas $1-1,5 \times 0,2-0,8 \mathrm{~mm}$, elípticas a ovadas, ou lineares a lanceoladas, margem inteira. Flores estaminadas cremes, ou ferrugíneas, 3-7,5 mm compr., pedicelos 1-4 mm compr.; sépalas $1,5-2,5 \times 0,8-1,2 \mathrm{~mm}$, elípticas a ovadas, face abaxial pubescente ou glabrescente; pétalas 5 , $1,6-2,7 \times 0,5-1 \mathrm{~mm}$, obovadas a espatuladas, ou oblongas; estames 16-23, 2-3 mm compr.; receptáculo piloso. Flores pistiladas amareloesverdeadas, 1,8-3,2 mm compr., pedicelos 1-1,6 $\mathrm{mm}$ compr., ou sésseis a subsésseis; sépalas 5, iguais a levemente desiguais, $1-2,3 \times 0,3-0,8 \mathrm{~mm}$, ovadas a triangulares, ou estreito-lanceoladas a lanceoladas, livres, face abaxial pubescente; disco nectarífero inteiro, glabro; pétalas 5 , lineares ou transformadas em glândulas, ou ausentes; ovários ca. 1-2 × 1-2 mm, elipsoides a globosos, hirsutopubescentes a tomentosos; estiletes unidos na base, 2-fidos, glabrescentes. Frutos 4,3-5,6 × 4-5 $\mathrm{mm}$, pubescentes a tomentosos, columelas ápice tripartido. Sementes $4 \times 2-2,5 \mathrm{~mm}$, elipsoides. 
Material examinado: Espinhaço, 25.II.2012, fl., F. Hurbath 244 (ALCB). Trilha para Cachoeirão, 26.II.2012, fr., F. Hurbath 260 (ALCB). Trilha para o Lameirão, 11.V.2012, fr., F. Hurbath 288 (ALCB). Caminho para a Pedra Preta, 21.I.2013, fl., F. Hurbath 421 (ALCB). Mata do Xaxá, 22.I.2013, fl., F. Hurbath 450 (ALCB).

Distribuição: A espécie desde a América Central até a América do Sul, e no Brasil distribuise nas regiões Nordeste, Centro-Oeste e Sudeste (Carneiro-Torres 2009; BFG 2015)

Comentários: Croton heliotropiifolius apresenta ampla variação morfológica, tanto nas estruturas vegetativas quanto nas reprodutivas. Ver comentários de $C$. campestris. Na SGLA, a espécie é encontrada em fitofisionomias de cerrado, cerrado antropizado, caatinga, campos rupestres e floresta estacional decidual.

\subsection{Croton hirtus L'Her., Stirp. Nov. 17. 1785}

Ervas eretas, ca. 0,3-1 m alt., monóicas; látex translúcido; ramos não viscosos, tricomas estrelados curto-estipitados porreticos. Limbos papiráceos, 32,8-45,7 × 28,4-39,6 mm, ovados a largo-ovados, venação cladódroma, ápice agudo, base obtusa a truncada, levemente retusa, margem duplodenteada, eglandulosa, face adaxial estrigosa, face abaxial glabrescente hirsuta, ambas com tricomas estrelados, face abaxial verde; glândulas presentes na base do limbo, 2, estipitadas, pateliformes; pecíolos 15,5-27 $\mathrm{mm}$; estípulas 4,7-5,4 × 0,5-1 $\mathrm{mm}$, lineares, margem inteira. Inflorescências 31-35 mm, raque pubescente; brácteas 1,2-1,8 $\times 0,5-0,7 \mathrm{~mm}$, lanceoladas, margem inteira com glândulas longo-estipitadas na porção proximal. Flores estaminadas cremes 4,4-5,4 mm, pedicelos 1,8-2,4 mm, sépalas 2-3 × 1-1,2 mm, elípticas a espatuladas, face abaxial pubescente; pétalas 5 , 2-2,5 × 0,8-1 mm, elípticas; estames 8-11, 3-3,3 $\mathrm{mm}$; receptáculo piloso. Flores pistiladas verdes, 4-5 mm, sésseis a subsésseis; sépalas 5, iguais, 2,5-3 × 0,8-1,2 mm, oblanceoladas, livres, face abaxial hirsuto pubescentes; disco nectarífero 5-lobados, glabro; pétalas ausentes; ovários 1,2-1,5 $\times 1,2-1,5 \mathrm{~mm}$, globosos, hirsutos; estiletes livres, 2-fidos, pubescentes. Frutos 4,9-5,6 × 4,7-4,9 $\mathrm{mm}$, hirsutos, columelas inteiras. Sementes 4-4,2 $\times$ 3-3,5 mm, largamente elipsoides.

Material examinado: Caminho para Pedra Preta, 21.I.2013, fl. e fr., F. Hurbath 420 (ALCB). Caminho para campo rupestre do Xaxá, 21.II.2014, fl. e fr., F. Hurbath 610.

Distribuição: A espécie possui ampla distribuição na região Neotropical, e no Brasil, distribui-se em todas as regiões do país e em todos os estados do Nordeste (Carneiro-Torres 2009; BFG 2015).

Comentários: Croton hirtus pode ser reconhecida pos apresentar hábito herbáceo, glândulas estipitadas na base do limbo. Na SGLA, a espécie é encontrada em fitofisionomia de cerrado e caatinga antropizada.

5.12 Croton imbricatus L.R. Lima \& Pirani, Kew Bull. 63(1): 122. 2008.

Arbustos eretos, ca. 1-1,3 m alt., monoicos; látex translúcido; ramos não viscosos, tricomas estrelado-lepidotos. Limbos papiráceos, 2-3,8 $\times$ 1,2-2,2 cm, elípticos a obovados, venação cladódroma, ápice acuminado a mucronado, margem inteira, eglandulosa, base acuminada a aguda, ou arredondada, face adaxial e face abaxial lepidota, ambas com tricomas estrelado-lepidotos, face abaxial cinérea a argêntea; glândulas presentes na base do limbo, 2, sésseis, lenticuladas; pecíolos 2,1-23 mm compr.; estípulas transformadas em glândulas. Inflorescências 8-23 mm compr.; raque lepidota; brácteas 1,5-2 × 0,5-1,2 mm, ovadas a triangulares, ou estreito-triangulares a lanceoladas, margem inteira. Flores estaminadas cremes, 5,5-8 mm compr., pedicelos 2,7-3,5 mm compr.; sépalas 1,2-2,4 × 1-1,5 mm, obovadas a elípticas, face abaxial esparso-lepidota; pétalas 5, 2-2,5 × 0,6-1 mm, espatuladas; estames 10-11, 2-3 mm compr.; receptáculo piloso. Flores pistiladas verde-cinéreos a verde-ferrugíneas, 3-3,5 mm compr., pedicelos 1-2,3mm compr.; sépalas 5, iguais, 2,4-2,8 $\times 1,5-2$ $\mathrm{mm}$, ovadas, livres, face abaxial lepidota; disco nectarífero 5-lobado, glabro; pétalas 5, transformadas em glândulas; ovários 1,8-2×2-2,2 mm, globosos, lepidotos; estiletes unidos na base, 2-fidos, glabros. Frutos 5,5-6,5 × 5,7-6,8 mm, lepidotos, columela inteira. Sementes não observadas.

Material examinado: Trilha Santana para o Cascarrento, 10.V.2012, fl. e fr., F. Hurbath 273 (ALCB). Subida para o Cascarrento, 10.V.2013, F. Hurbath 439 (ALCB). Campo rupestre do Xaxá, 23.V.2013, fl., F. Hurbath 546 (ALCB). Xaxá, 23.V.2013, fl., F. Hurbath 547 (ALCB).

Distribuição: Endêmica da porção bahiana da Cadeia do Espinhaço (Carneiro-Torres 2009; BFG 2015).

Comentários: Croton imbricatus pode ser reconhecido por apresentar ambas as faces do limbo lepidotas, um par de glândulas na base do limbo e estiletes 2-fidos. Na SGLA, a espécie é encontrada em campos rupestres, caatinga sobre afloramento rochoso e cerrado de altitude. 
5.13 Croton jacobinensis Baill., Adansonia 4: 302. 1864.

Fig. 3a-g

Arbustos eretos, ca. 0,7-1,5 m alt., monoicos; látex translúcido; ramos não viscosos, tricomas estrelados estipitados, transição para lepidotos. Limbos papiráceos, 3,6-13,2 × 2,4-8 cm, ovados ou cordiformes, venação cladódroma, ápice agudo a apiculado, margem inteira, eglandulosa, base cordada, face adaxial pubescente, face abaxial tomentosa, ambas com tricomas estrelados, face abaxial glauca; glândulas ausentes na base do limbo; pecíolos 1,1-5 cm compr.; estípulas 4-7 $\times 0,5-2 \mathrm{~mm}$, lineares a falciformes, margem inteira. Inflorescências 5,3-9,8 cm compr.; raque tomentosa; brácteas $2-4,2 \times 1 \mathrm{~mm}$, estreitotriangulares a lanceoladas, margem inteira. Flores estaminadas cremes, 5,7-8,9 mm compr., pedicelos 1,5-3 mm compr.; sépalas 3-4×2-2,7 mm, elípticas a ovadas, face abaxial tomentosa; pétalas 5, 3-4 $\times$ 1,5-2 mm, elípticas a ovadas; estames 13-16, 4-5 $\mathrm{mm}$ compr.; receptáculo piloso. Flores pistiladas verdes, 5-8 mm compr., pedicelos $0,8-1,5 \mathrm{~mm}$ compr.; sépalas 5, iguais, $5 \times 3-3,2 \mathrm{~mm}$, elípticas a ovadas, unidas na porção basal e parcialmente ao ovário, face abaxial tomentosa; disco nectarífero 5-lobado, tomentoso; pétalas 5, 1,6-1,8 × 0,8-1 $\mathrm{mm}$, ovadas a lanceoladas, ou ausentes; ovários ca. $3 \times 3 \mathrm{~mm}$, globosos, tomentosos; estiletes unidos na base, $8-10$-fidos, glabrescentes. Frutos $8 \times 8,1 \mathrm{~mm}$ compr., tomentosos, columelas inteiras. Sementes ca. $6 \times 4 \mathrm{~mm}$ ovoides.

Material examinado: São Domingos, 25.II.2013, fl. e fr., F. Hurbath 254 (ALCB). Santa Clara, 25.V.2013, fl. e fr., F. Hurbath 588 (ALCB).

Distribuição: É endêmica do bioma Caatinga com distribuição no Nordeste e Sudeste do Brasil (Carneiro-Torres 2009; BFG 2015).

Comentários: Croton jacobinensis pode ser reconhecida por apresentar limbo ovado a cordado, estípulas lineares a falciformes, estiletes multífidos, frutos verdes e tomentosos. Alguns indivíduos na área de estudo apresentam pétalas nas flores pistiladas, caráter inédito para C. jacobinensis. A espécie é endêmica do bioma Caatinga (CarneiroTorres 2009) e na SGLA, é encontrada em fitofisionomias de caatinga e ecótonos entre esta última e cerrado.

5.14 Croton laceratoglandulosus Caruzo \& Cordeiro, Bot. J. Linn. Soc. 158: 493. 2008.

Arbustos eretos, ca. 1-1,5 m alt., monoicos; látex alaranjado; ramos não viscosos, tricomas estrelados sésseis a estipitados. Limbos membranáceos a papiráceos, 9,1-12,4 × 6,3-9,1 $\mathrm{cm}$, ovados ou cordiformes, venação actinódroma, ápice agudo, margem inteira com glândulas estipitadas, base cordada, face adaxial glabrescente, face abaxial pubescente a tomentosa, ambas com tricomas estrelados, face abaxial levemente glauca; glândulas ausentes na base do limbo; pecíolos 5,5-10,3 cm compr.; estípulas $8 \times 19,2 \mathrm{~mm}$, fimbriadas com glândulas, profundamente partidas. Inflorescências $14 \mathrm{~cm}$; raque pubescente ou hirsuta; brácteas 4,5-5 × 3,5-4 mm, espatuladas, margem recortada com glândulas. Flores estaminadas cremes, 10,4-11,5 mm compr., pedicelos 4,8-5 $\mathrm{mm}$ compr.; sépalas 4-4,2 × 2,2-2,8 mm, ovadas, face abaxial, pubescente a tomentosa; pétalas 5 , $5 \times 2,2-3 \mathrm{~mm}$, obovadas; estames $65,5-6 \mathrm{~mm}$ compr.; receptáculo piloso. Flores pistiladas esverdeadas, 9-9,7 mm compr., sésseis; sépalas 5, iguais, 4,3-4,7 ×5,1-5,6 mm, flabeliformes, livres, face abaxial tomentosa; disco nectarífero inteiro, glabro a glabrescente; pétalas 5 , transformadas em glândulas; ovários 1,7-1,8 × 1,8-2,3 mm, transversalmente elipsoides a globosos, tomentosos a hirsutos; estiletes unidos na base, 4-5-fidos, glabrescentes. Frutos, columelas e sementes não observados.

Material examinado: Distrito de São Domingos, Fazenda São Domingos, 10.XII.2009, fl. e fr., E. Melo 588 (ALCB, HUEFS).

Distribuição: A espécie é registrada para Bolívia e Brasil (Cordeiro et al. 2008; CarneiroTorres 2009). Neste último, ocorre nas regiões Nordeste e Sudeste (Cordeiro et al. 2008; CarneiroTorres 2009; BFG 2015).

Comentários: Croton laceratoglandulosus é reconhecida por apresentar folhas longopecioladas, estípulas fimbriadas com glândulas, profundamente partidas, estames numerosos (65), estiletes multífidos e sépalas flabeliformes. $\mathrm{Na}$ SGLA, a espécie é encontrada em fitofisionomia de ecótono entre caatinga e cerrado.

5.15 Croton mucronifolius Müll. Arg., Fl. bras. 11(2): 216.1874.

Arbustos eretos, ca. 0,6-0,7 m alt., monoicos; látex translúcido; ramos não viscosos, tricomas estrelados curto-estipitados porréticos. Limbos cartáceos, 2,6-5,5 × 1-2,2 cm, ovados ou cordiformes, venação actinódroma, ápice apiculado a aristado, margem serreada com glândulas estipitadas, base arredondada a cordada, face adaxial pubescente e escabra, face abaxial tomentosa, ambas com tricomas estrelados, face 

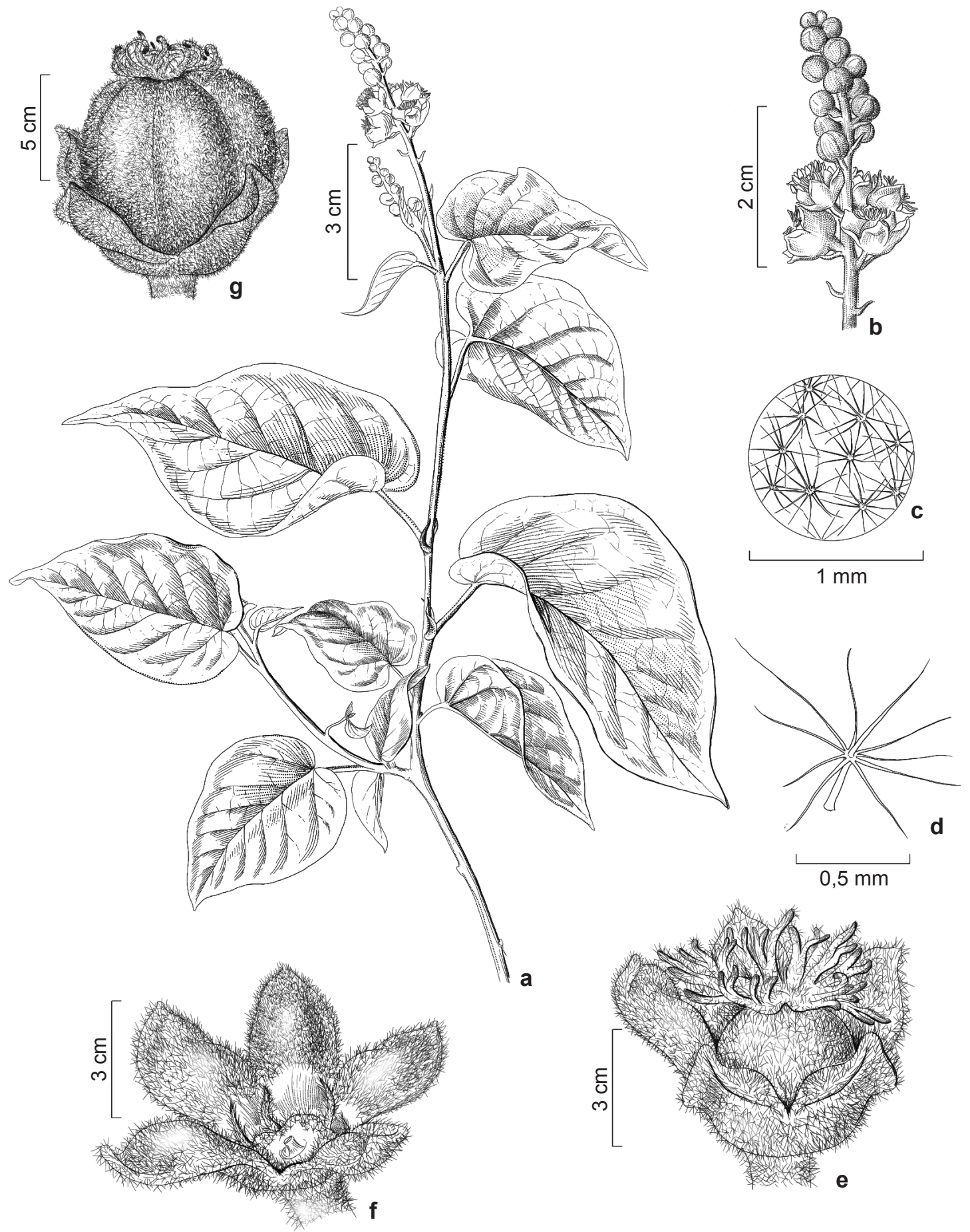

Figura 3 - a-g. Croton jacobinensis - a. ramo fértil; b. inflorescência; c. detalhe do indumento da face abaxial das folhas; d. tricoma estrelado porrético; e. flor pistilada; f. perianto da flor pistilada, pétalas intercalando com as sépalas e disco nectarífero tomentoso; g. fruto. (a-g. F. Hurbath 254/288).

Figure 3 - a-g. Croton jacobinensis - a. fertile branch; b. inflorescence; c. detail of the indument of abaxial surface of the leaves; $d$. stellate-porrect trichome; e. pistillate flower; f. pistillate flower perianth, petals between sepals, tomentose nectary disk; g. fruit. (a-g. F. Hurbath 254/288). 
abaxial levemente glauca; glândulas presentes na base do limbo, 2-4, estipitadas, capitadas; pecíolos 2,1-5,2 mm compr.; estípulas 1,3-1,5 × 0,2-0,3 $\mathrm{mm}$, lineares a estreito-triangulares, margem inteira. Inflorescências 3,7-12,5 cm compr.; raque tomentosa; brácteas 2-3,6 mm compr., lineares a estreito-lanceoladas, margem inteira. Flores estaminadas cremes, 5,6-8 $\mathrm{mm}$ compr., pedicelos 2,3-4 mm compr.; sépalas 2-3 × 1-1,5 mm, elípticas a levemente ovadas, face abaxial tomentosa; pétalas 5, 2,3-2,8 × $1 \mathrm{~mm}$, espatuladas a oblanceoladas; estames 11, 3-4 mm compr.; receptáculo piloso. Flores pistiladas esverdeadas, 3,5-4,5 mm compr., pedicelos 1,2-2 mm compr; sépalas 6, levemente desiguais, 2,8-3,5 × 0,5-1,1 mm, lanceoladas, livres, face abaxial tomentosa; disco nectarífero glabro; pétalas ausentes; ovários 1,3-1,5 × 1,3-1,5 $\mathrm{mm}$, globosos, tomentosos; estiletes livres, 2-fidos, glabrescentes. Frutos 4,5-5 $\times 4 \mathrm{~mm}$, pubescentes a estrigosos, columelas inteiras. Sementes 3,5-4 × 2 $\mathrm{mm}$, elipsoides a ovoides.

Material examinado: São Domingos, estrada para Caetité, 25.II.2013, fl. e fr., F. Hurbath 251 (ALCB). 25.V.2013, fl. e fr., F. Hurbath 588 (ALCB).

Distribuição: Endêmica do Brasil, ocorre nas regiões Nordeste, Centro-Oeste e Sudeste (Carneiro-Torres 2009; BFG 2015).

Comentários: Croton mucronifolius é reconhecida por apresentar folhas curtamente pecioladas, actinódromas, limbo ovado com ápice apiculado a aristado, face abaxial levemente glauca. É semelhante a Croton agoensis Baill. pela similaridade do tipo de indumento, venação, formato e tipo de margem do limbo. Difere-se desta por apresentar margem das folhas com glândulas (vs. glândulas ausentes), sépalas das flores estaminadas e pistiladas com face abaxial tomentosa ( $v s$. pubescente) e estiletes livre ( $v s$. unidos na base). Na SGLA, a espécie é encontrada em fitofisionomia de ecótono entre caatinga e cerrado.

5.16 Croton nummularius Baill. Adansonia 4: 360. 1864

Arbustos prostrados, ca. 0,1-0,2 m alt., monoicos; látex translúcido; ramos não viscosos, tricomas estrelado curto-estipitados porreticos. Limbos papiráceos, $0,7-1 \times 0,57-0,64 \mathrm{~cm}$, elípticos a largo-elípticos, venação cladódroma, ápice retuso, base truncada a retusa, margem denteada com glândulas sésseis, face adaxial glabra, face abaxial pubescente, com tricomas estrelados, verde; glândulas ausentes na base do limbo; pecíolos 3-5,2 $\mathrm{mm}$; estípulas $1,2-1,4 \times 1,1-1,2 \mathrm{~mm}$, laciniadas com glândulas. Inflorescências 5,8-10,8 mm, pubescentes; brácteas $0,5-0,8 \times 1-1,2 \mathrm{~mm}$, ovadas, margem inteira, fimbriada na porção proximal. Flores estaminadas cremes, 3-3,5 mm, pedicelos 0,8-1,1 mm; sépalas 1,8-2 × 1-1,2 mm, ovadas, face abaxial glabrescente; pétalas $5,1,2-1,6 \times$ 0,6-0,8 mm, elípticas a levemente espatuladas; estames 8 a 9, 2-2,7 mm, receptáculo piloso. Flores pistiladas verde-amareladas, 4-6 $\mathrm{mm}$, pedicelos 0,7-1 mm, sépalas 5, iguais, 2,2-4,8 × 1,8-2 $\mathrm{mm}$, ovadas livres, face abaxial pubescente com glândulas estipitadas; disco nectarífero 5-lobados, glabro; pétalas tranformadas em glândulas; ovários 0,3-0,7 × 0,2-0,6 mm, globosos, hirsutos; estiletes unidos na base, 4-5-fidos, glabrescentes. Frutos 2,9-3 × 2,7-2,8 mm, glabrescentes, columelas inteiras. Sementes 2-2,2-1,5-1,7 mm, elipsoides. Material examinado: Cascarrento, 06.VIII.2014, fl. e fr., N. Roque 4448 (ALCB).

Distribuição no Brasil: A espécie ocorre no Brasil em Minas Gerais, Bahia e Pernambuco (Carneiro-Torres 2009; BFG 2015).

Comentários: Croton nummularius assemelha-se a $C$. radlkoferi Pax. \& K. Hoffm. Por apresentar folhas com limbo de até $1 \mathrm{~cm}$ de comprimento e sépalas das flores pistiladas com glândulas estipitadas, diferindo desta pode apresentar hábito prostrado. Na SGLA, a espécie é encontrada em fitofisionomia de cerrado de altitude.

5.17 Croton pedicellatus Kunth, Nov. Gen. Sp. 2: 75.1817 .

Arbustos eretos, ca. $1 \mathrm{~m}$ alt., monoicos; látex translúcido; ramos não viscosos, tricomas estrelados estipitados. Limbos papiráceos a cartáceos, 2,4-4,3 × 0,8-2,1 cm, ovados a elípticos, venação cladódroma, ápice agudo a acuminado, margem inteira, eglandulosa, base aguda a arredondada, face adaxial pubescente, face abaxial lanosa, ambas com tricomas estrelados, face abaxial creme; glândulas ausentes na base do limbo; pecíolos 3,8-7,3 mm compr.; estípulas $1,5-1,8 \times 0,4-0,5 \mathrm{~mm}$, estreito-triangulares a lanceoladas, margem inteira. Inflorescências terminais e axilares, 1,4-2,1 cm compr.; raque pubescente; brácteas 1,5-2 mm compr., lineares, margem inteira. Flores estaminadas cremes, 4-5 mm compr., pedicelos ca. $2 \mathrm{~mm}$ compr.; sépalas 1,8-2,4 × 1-1,5 mm, elípticas a ovadas, face abaxial pubescente; pétalas 5, 1,5-2 ×0,4 mm, oblongas; estames 11-12, 1,8-2 mm compr.; receptáculo piloso. Flores pistiladas verde-claras, 3-4 mm 
compr., pedicelos 1,5-2 mm compr.; sépalas 5, iguais, $1,5-2,5 \times 0,5-0,7 \mathrm{~mm}$, oblongas, livres, face abaxial pubescente; disco nectarífero 5-lobado, glabro; pétalas 5, lineares; ovários 1,5-3 × 1,5-2,5 $\mathrm{mm}$, globosos, hirsuto-pubescentes; estiletes unidos na base, 2-fidos, pubescentes. Frutos $5 \times$ $4 \mathrm{~mm}$, hispidulosos, columelas inteiras. Sementes ca. $3 \times 2 \mathrm{~mm}$, elipsoides.

Material examinado: Boqueirão, 24.II.2012, fl. e fr., $F$. Hurbath 232 (ALCB).

Distribuição no Brasil: A espécie ocorre na América Central e América do Sul, e no Brasil possui ampla distribuição abrangendo todas as regiões geográficas (Carneiro-Torres 2009; BFG 2015).

Comentários: Croton pedicellatus pode ser reconhecida por apresentar folhas com limbo ovado a elíptico, 2,4-4,3 compr., flores pistiladas pediceladas e columela inteira. Na SGLA, a espécie é encontrada em fitofisionomia de cerrado.

5.18 Croton rudolphianus Müll. Arg., Prodr. 15(2): 654. 1866.

Arbustos eretos, ca. 0,8-1,2 m alt., monoicos; látex translúcido; ramos não viscosos, tricomas estrelados sésseis a curto-estipitados. Limbos papiráceos a cartáceos, 3,1-5,7 × 1,6-4 cm, ovados ou cordiformes, venação cladódroma, ápice atenuado a acuminado, ou agudo, margem serreada a duploserreada, eglandulosa, base arredondada a truncada, ou retusa a cordada, face adaxial glabrescente, face abaxial esparso pubescente a glabrescente, ambas com tricomas estrelados, face abaxial verde; glândulas ausentes na base do limbo; pecíolos 1-3,2 cm compr.; estípulas 0,7-3×0,5-1 mm, palmatífidas a pinatífidas, margem fimbriado-glandulosa. Inflorescências raro axilares, 1,9-5,7 cm compr.; raque tomentosa a pubescente; brácteas 1-2,5 $\times 0,5-1 \mathrm{~mm}$, elípticas a ovadas, ou lanceoladas, margem inteira. Flores estaminadas cremes, 2-3,5 mm compr., pedicelos 0,7-1,5 mm compr.; sépalas 2,1-3 × 1,1-1,5 mm, elípticas a ovadas, face abaxial esparso-pubescentes a pubescentes; pétalas 5, 2,1-3 × 1,3-1,8 mm, obovadas; estames 8-11, 2-3 mm compr.; receptáculo glabrescente. Flores pistiladas verdes com estigmas alvos, 3,5-5 mm compr., pedicelos 0,6-1,1 mm compr.; sépalas 5, iguais, 2,5-4 × 1,2-2 mm, obovadas ou panduradas a oblongas, livres, margem com glândulas, face abaxial pubescente; disco nectarífero inteiro, glabro; pétalas ausentes; ovários 1,1-2 × 1-2 mm, globosos, pubescentes; estiletes unidos na base, 4(5)-fidos, glabros a papilosos. Frutos 4,5-5 × 4,5-5 mm, glabrescentes, columelas inteiras. Sementes 2,2-4 $\times 2-4 \mathrm{~mm}$, elipsoides.

Material examinado: Garimpo dos Areiões, 22.II.2012, fl. e fr., F. Hurbath 242 (ALCB). Cascarrento, 22.I.2013, fl., F. Hurbath 438 (ALCB). Garimpo das Ametistas, 5.XI.2013, fl., F. Hurbath 605 (ALCB).

Distribuição: A espécie é endêmica do Brasil e distribui-se nas Regiões Nordeste e Sudeste (Carneiro-Torres 2009; BFG 2015).

Comentários: Croton rudolphianus pode ser reconhecida pela ausência de glândulas na base do limbo, sépalas das flores pistiladas pubescentes e estípulas com margem fimbriado-gladulosa. $\mathrm{Na}$ SGLA, a espécie é encontrada em fitofisionomia de caatinga, caatinga sobre afloramento rochoso e cerrado de altitude.

5.19 Croton triangularis Müll. Arg., Linnaea 34: 128. 1865 .

Arbustos eretos, ca. 0,7-1 m alt., monoicos; látex translúcido; ramos não viscosos, tricomas estrelados curto-estipitados porréticos. Limbos papiráceos, 4-6,7 $\times 3-5,5 \mathrm{~cm}$, cordiformes, venação actinódroma, ápice agudo, margem erosa com glândulas estipitadas, base cordada, face adaxial escabra, face abaxial tomentosa, ambas com tricomas estrelados, face abaxial glauca; glândulas presentes na base do limbo, 2, estipitadas, pateliformes; pecíolos 1-3,5 cm compr.; estípulas 3-5 × 0,5-0,7 mm, estreito-lanceoladas, margem inteira. Inflorescências 6,7-15,6 cm compr.; raque tomentosa, brácteas $2,2-3 \times 0,2-0,7 \mathrm{~mm}$, ovadas a lanceoladas, ou lineares, margem inteira. Flores estaminadas cremes, 3,8-5,3 mm compr., pedicelos 1-2,2 mm compr.; sépalas 5, 1,5-2,5 × 0,5-1,5 mm, elípticas, face abaxial tomentosa; pétalas 5, 1,3-2,2 $\times 0,5-1 \mathrm{~mm}$, obovadas a espatuladas; estames 10-11, 2,5-4,2 mm compr.; receptáculo piloso. Flores pistiladas verde-amareladas, 3,8-7 $\mathrm{mm}$ compr., pedicelos 1,1-2 mm compr.; sépalas 5, desiguais, três maiores, duas menores, 2,5-5 × 1,1-4,5 mm, ovadas a largo-elípticas, unidas na porção basal, face abaxial tomentosa; disco nectarífero 5-lobado, glabro; pétalas ausentes; ovários 2-3 × 2-3,3 mm, globosos, tomentosos; estiletes unidos na base, 4-6-fidos, glabrescentes. Frutos 4-8 × 4-7 mm, tomentosos, columelas inteiras. Sementes 2,5-5 × 1,3-3,5 mm, elipsoides a largo-elipsoides.

Material examinado: Distrito de São Domingos, 10.XII.2012, fl. e fr., E. Melo 7389 (ALCB, HUEFS). Ca. $2 \mathrm{~km}$ após o povoado de Riacho Fundo, estrada de terra para Licínio de Almeida, 11.XII.2012, fl. e fr., $E$. Melo 7493 (ALCB, HUEFS). Caminho para Riacho de Areia, 21.I.2013, fl., F. Hurbath 424 (ALCB). Xaxá, 22.I.2013, fl., F. Hurbath 448 (ALCB). 
Distribuição: A espécie é endêmica do Brasil e distribui-se pelos estados da Bahia e Minas Gerais (Carneiro-Torres 2009; BFG 2015).

Comentários: Croton triangularis é facilmente reconhecida em campo por apresentar suas folhas com base do limbo cordada, margem erosa com glândulas estipitadas entre as serras e na base do limbo, inflorescências longas (6,7-15,6 cm compr.). Ver comentário de $C$. adamantinus. Na SGLA, a espécie é encontrada em fitofisionomias de caatinga e cerrado e em ecótonos entre estas duas fitofisionomias. Segundo Carneiro-Torres (2009), está com seu status de conservação vulnerável segundo critérios da IUCN (2001).

5.20 Croton tricolor Klotzsch ex Baill. Adansonia 4: 291.1864.

Arbustos eretos, ca. 1,3 m alt., dióicos; látex translúcido; ramos não viscosos, tricomas estreladolepidotos. Limbos membranáceos a papiráceos, 3,4-5,4 × 1,7-2,1 cm, elípticos a ovados, venação cladódroma, ápice mucronado a retuso, margem inteira, eglandulosa, base truncada a levemente retusa, face adaxial esparso-pubescente, com tricomas estrelados, face abaxial lepidota, com tricomas estrelado-lepidotos, argêntea; glândulas ausentes na base do limbo; pecíolos $8-12 \mathrm{~mm}$ compr.; estípulas $0,4-1 \times 0,1-0,2 \mathrm{~mm}$, lineares a lanceoladas, margem inteira. Inflorescências terminais e axilares, $3-7,5 \mathrm{~cm}$ compr.; raque lepidota; brácteas $1,4 \times 0,3 \mathrm{~mm}$, lanceoladas, margem inteira. Flores estaminadas cremes a ferrugíneas, 3,8-5,7 mm compr., pedicelos 2,3-3,2 $\mathrm{mm}$ compr.; sépalas 1,5-2 ×0,5-1 mm, elípticas, face abaxial lepidota; pétalas $5,1,8-2 \times 0,4-0,5$ $\mathrm{mm}$, oblongo-lanceoladas; estames 11, 2-2,5 mm compr.; receptáculo piloso. Flores pistiladas argênteas a ferrugíneas, 5-7 mm compr.; pedicelos 3-4,5 mm; sépalas 5, iguais, $3 \times 2-2,2 \mathrm{~mm}$, ovadas, unidas na porção basal, face abaxial lepidota; disco nectarífero 5-lobado, lepidoto; pétalas ausentes; ovários ca. $2,4 \times 2,5 \mathrm{~mm}$, globosos com projeções no ápice, lepidotos; estiletes unidos na base, 6-12-fidos, pubescente-lepidotos. Frutos, columelas e sementes não observadas.

Material examinado: Mata do Xaxá, 22.I.2013, fl., F. Hurbath 454 (ALCB).

Material adicional examinado: BRASIL. BAHIA: Morro do Chapéu, Próximo ao Ferro Doido, 13.III.1996, fl. e fr., E. Woodgyer 2343 (ALCB).

Distribuição: A espécie ocorre na Venezuela, Bolívia e no Brasil, neste último, nas regiões
Nordeste, Sudeste e Sul (Carneiro-Torres 2009; BFG 2015).

Comentários: Croton tricolor assemelhase a $C$. argyrophyllus. Ver comentários em $C$. argyrophyllus. Na SGLA, a espécie é encontrada em floresta estacional decidual.

5.21 Croton triqueter Lam., Encycl. 2: 214. 1786. Arbustos eretos, ca. 0,6-1 m alt., monoicos; látex translúcido; ramos não viscosos, tricomas estrelados longo-estipitados porreticos. Limbos cartáceos, 5,9-8,7 × 3,8-4,7 cm, elípticos a ovados, venação actinódroma, ápice agudo a acuminado, margem serrulada, eglandulosa, base atenuada a arredondada, face adaxial pubescente e escabra, ou tomentosa, face abaxial tomentosa, ambas com tricomas estrelados, face abaxial amarelada; glândulas ausentes na base do limbo; pecíolos $1,1-3,2 \mathrm{~cm}$ compr.; estípulas $4-6 \times 0,3-0,8$ $\mathrm{mm}$, lineares a estreito-lanceoladas, margem inteira. Inflorescências 1,3-3 cm compr.; raque tomentosa; brácteas 4,5-8 mm compr., espatuladas a unguiculadas com margem fimbriada (flores estaminadas), a pinatifida (flores pistiladas). Flores estaminadas amareladas, 5,1-6,8 $\mathrm{mm}$ compr., pedicelos 2-2,7 mm compr.; sépalas 5, $3 \times 2 \mathrm{~mm}$, ovadas a triangulares, face abaxial tomentosa; pétalas 5, 3,5-4 × 0,5 mm, espatuladas; estames 11 , receptáculo piloso. Flores pistiladas amareladas, 6-8 mm compr., pedicelos ca. 0,6 mm compr.; sépalas 5 , desiguais, três maiores, duas menores, 5-7 $\times 1,5-4 \mathrm{~mm}, 3$ lanceoladas a oblongas e pinatífidas, 2 lineares, livres, face abaxial tomentosa; disco nectarífero inteiro ou 5-lobado, glabro; pétalas ausentes; ovários 1,2-2 × 1,8-2 mm, elipsoides a globosos, tomentosos; estiletes unidos na base, 4-6(7)-fidos, glabrescentes. Frutos 4-5× 4-5 mm, tomentosos, columelas inteiras. Sementes 2,7-3 $\times 1,2-2 \mathrm{~mm}$, elipsoides.

Material examinado: Trilha para o Cachoeirão, 26.II.2012, fl. e fr., F. Hurbath 258 (ALCB). Trilha para o Cachoeirão, 26.II.2012, fr., F. Hurbath 262 (ALCB).

Distribuição: A espécie ocorre desde a América do Norte, no México, na América Central e na América do Sul. No Brasil é amplamente distribuída (Carneiro-Torres 2009; BFG 2015).

Comentários: Croton triqueter pode ser reconhecida por apresentar folhas actinódromas, com face abaxial amarelada, flores pistiladas com sépalas desiguais e estiletes 4-6(7)-fidos. Na SGLA, a espécie é encontrada em fitofisionomias de caatinga antropizada e mata de galeria degradada. 
5.22 Croton urticifolius Lam., Encycl 2: 219. 1786.

Arbustos eretos, ca. 1-1,3 m alt., monoicos; látex translúcido; ramos não viscosos, tricomas estrelados estipitados porréticos. Limbos papiráceos, 3,4-6,9 × 2,1-3,8 cm, ovados ou cordiformes, venação actinódroma; ápice agudo, margem crenada, eglandulosa, base cordada, face adaxial pubescente, face abaxial tomentosa, ambas com tricomas estrelados, face abaxial glauca a creme; glândulas ausentes na base do limbo; pecíolos 7-2 mm compr., estípulas $0,5-0,7$ $\times 0,2-0,4 \mathrm{~mm}$, ovadas, margem inteira com um par de glândulas na base. Inflorescências 5,5-7,8 $\mathrm{cm}$ compr.; raque tomentosa, brácteas $1 \times 1 \mathrm{~mm}$, ovadas a triangulares, margem inteira. Flores estaminadas verdes e cremes, $6,1-6,6 \mathrm{~mm}$ compr., pedicelos 1,3-1,5 mm compr., sépalas $3 \times 1,5-2$ $\mathrm{mm}$, elípticas, face abaxial tomentosa; pétalas 5 , $3-3,5 \times 1-1,5 \mathrm{~mm}$, espatuladas a unguiculadas; estames 11-13, 3-4 mm compr.; receptáculo piloso. Flores pistiladas verde-amareladas, 3-5 mm compr., pedicelos 1-2,2 mm compr.; sépalas 5, levemente desiguais, 2,5-5 × 1,2-3 mm, elípticas a ovadas, ou obovadas, unidas na porção basal, margem com glândulas na porção inferior, face abaxial tomentosa; disco nectarífero 5-lobado, glabro; pétalas ausentes; ovários 2-3 $32 \mathrm{~mm}$, globosos, tomentosos; estiletes unidos na base, 5-7-fidos, pubescentes. Frutos $4 \times 4 \mathrm{~mm}$, globosos, tomentosos, columelas inteiras. Sementes ca. $3 \times$ $2 \mathrm{~mm}$, elipsoides.

Material examinado: Boqueirão, 24.II.2013, fr., F. Hurbath 234 (ALCB). Trilha Xaxá-Cachoeirão, 23.I.2013, fl., F. Hurbath 461 (ALCB).

Distribuição: A espécie é endêmica do Brasil, distribui-se pelas regiões Norte, Nordeste e Sudeste (Carneiro-Torres 2009; Cordeiro et al. 2013).

Comentários: Croton urticifolius pode ser reconhecida por apresentar margens dos limbos erosas, ausência de glândulas na base destes e estiletes 5-7-fidos. Na SGLA, a espécie é encontrada em fitofisionomias de cerrado e campos rupestres.

5.23 Croton virgultosus Müll. Arg., Fl. bras. 11(2): 104. 1873.

Arbustos eretos, ca. $2 \mathrm{~m}$ alt., monoicos; látex translúcido; ramos não viscosos, tricomas estrelados curto-estipitados. Limbos papiráceos a cartáceos, 4,5-6,3 × 2,6-3,3 cm, ovados, venação actinódroma, ápice agudo, margem crenada a duplo serrilhada com glândulas curto-estipitadas, base obtusa a retusa, face adaxial glabrescente, face abaxial tomentosa, ambas com tricomas estrelados, face abaxial glauca; glândulas presentes na base do limbo, 2-4, subssésseis, discoides; pecíolos 7,4-11,3 mm compr.; estípulas $0,5-0,8$ $\times 0,3-0,4$, ovadas, margem inteira com glândulas. Inflorescências ca. 6,2 cm compr.; raque pubescente; brácteas $2 \mathrm{~mm}$ compr., lineares, margem inteira. Flores estaminadas cremes, 3,8-4,3 mm compr., pedicelos 1,8-2,1 mm compr.; sépalas 5, 1,5-2,3× 1-1,4 mm, ovadas, face abaxial pubescente; pétalas $5,1,2-2,5 \times 0,5-0,9 \mathrm{~mm}$, espatuladas; estames 10 , 3,2-4,2 mm compr.; receptáculo piloso. Flores pistiladas alvas, 5-6 mm compr., pedicelos $0,5-0,7$ mm compr.; sépalas 5 , iguais, $2,5-3,5 \times 0,8-1$ $\mathrm{mm}$, ovadas a lanceoladas, livres, face abaxial pubescente; disco nectarífero 5-lobado, glabro; pétalas 5 , transformadas em glândulas; ovários $1,2-1,5 \times 1,1-1,2 \mathrm{~mm}$, globosos, tomentosos a hirsutos; estiletes unidos na base, 2-fidos, pubescente a glabrescente. Frutos, columelas e sementes não observados.

Material examinado: Serra do Jambeiro, 4.XI.2006, fl. e fr., A. Rapini 1337 (HUEFS).

Distribuição: A espécie é endêmica do Brasil, distribui-se pelas regiões Nordeste e Sudeste (Carneiro-Torres 2009; Cordeiro et al. 2013).

Comentários: Croton virgultosus assemelhase a $C$. adamantinus pela similaridade no formato das folhas, margem e indumento da face abaxial do limbo. Contudo, diferencia-se pela dobro do tamanho das inflorescências ( $v s .1,5-3 \mathrm{~cm}$ compr.), pétalas das flores estaminadas espatuladas ( $v s$. oblongas), e pétalas das flores pistiladas transformadas em glândulas (vs. pétalas ausentes). Sem especificação da fitofisionomia onde foi coletada.

\section{Dalechampia L., Sp. Pl. 2: 1054. 1753.}

Subarbustos, arbustos ou trepadeiras volúveis, monóicas; indumento com tricomas tectores geralmente urticantes, normalmente é possível visualizar o exsudato em seu interior; látex ausente. Folhas alternas, limbo inteiro a profundamente lobado; glândulas ausentes na base do limbo. Inflorescências axilares ou terminais, pseudantos; brácteas geralmente vistosas. Flores estaminadas em pleiocásio terminal, 8-12, monoclamídeas; sépalas livres, geralmente $4-5$; estames unidos formando uma coluna, 8-numerosos; presença ou não de bractéolas resiníferas. Flores pistiladas em um dicásio congesto inserido acima da bráctea inferior, 3, monoclamídeas; sépalas livres ou unidas, 5-12; presença de 1-2 brácteas livres ou fusionadas; ovário 
trilocular, estiletes unidos em uma coluna alongada, as vezes lobada ou dilatada no ápice, inteiros. Fruto cápsula septicida (cálice persistente geralmente com tricomas rígidos), indumento variado, columela persistente. Sementes sem carúncula.

O gênero é pantropical com cerca de 110 espécies (Radcliffe-Smith 2001), das quais 72 ocorrem no Brasil (BFG 2015). É caracterizado pela presença de brácteas involucrais geralmente vistosas e com grande variação morfológica, bem como a presença de bractéolas resiníferas que podem produzir compostos que atraem polinizadores (Webster \& Armbruster 1991). Na SGLA, está representado por duas espécies.

\section{Chave de identificação das espécies de Dalechampia da SGLA}

1. Estipelas ovadas; pecíolos 3,5-6,3 cm compr.; brácteas involucrais 1,4-1,7 × 1,3-2,1 cm; 7 flores estaminadas com 5 sépalas cada; flores pistiladas subsésseis; estiletes com $5 \mathrm{~mm}$ compr., dilatados no ápice 6.1. D. scandens

1'. Estipelas lanceoladas a oblongas; pecíolos 7-8 cm compr.; brácteas involucrais 5,8-6,2 × 4,9-5,2 cm; 10-12 flores estaminadas com 3 sépalas cada; flores pistiladas com pedicelos 1-1,6 mm compr.; estiletes 1,6-1,7 cm compr., estreitos no ápice..... 6.2. D. peckoltiana

6.1 Dalechampia scandens L., Sp. Pl. 2: 1054. 1753.

Trepadeiras, ramos não viscosos, esparsopubescentes. Limbos papiráceos a membranáceos, 3-palmatilobados, lobos centrais 5,2-7,8 $\times 2-3,1$ $\mathrm{cm}$, elípticos, lobos laterais 4,8-7,3 × 1,8-3,1 cm, elípticos, venação actinódroma, ápice acuminado, margem inteira a levemente serrulada, eglandulosa, base cordada, face adaxial glabrescente, face abaxial pubescente, ambas com tricomas tectores, face abaxial verde; estipelas $0,8-10 \times 0,5 \mathrm{~mm}$, ovadas; pecíolos 3,5-6,3 cm compr.; estípulas 3,8$6,2 \times 1,5-2,3 \mathrm{~mm}$, lanceoladas, margem inteira. Inflorescências axilares; brácteas involucrais 1,4-1,7 × 1,3-2,1 cm, 3-lobadas, lobos 1,2-3,1 $\times 1,1-1,3 \mathrm{~cm}$, margem serrulada a lacerada, base truncada, alvas; estípulas das brácteas 2,8-3× 0,5-0,6 mm, ovadas; brácteas masculinas $2-3$, 2-2,4 × 4,2-5,8 mm, flabeliformes; bractéolas resiníferas $2-2,7 \times 1,5-2 \mathrm{~mm}$, largo-elípticas, ápice truncado; brácteas femininas $2-3,2-3 \times$ $3,7-4,2 \mathrm{~mm}$, largo-elípticas. Flores estaminadas 7 , 4,5-6,7 mm compr.; pedicelos 2,3-4 mm compr.; sépalas 5, 2,5-3 × 1,2-2 mm, elípticas, glabras; estames numerosos, glabros. Flores pistiladas 3, 5-6,5 mm compr.; bractéolas ausentes; subséssil; sépalas 3-3,4 × 0,6-0,9 mm, pinatífidas, livres, face abaxial velutinosa; ovários ca. $0,5 \times 1 \mathrm{~mm}$, tranversalmente elipsoides, lóculos proeminentes, hirsutulosos; estilete dilatado no ápice, ca. $5 \mathrm{~mm}$ compr. Frutos 4,6 $\times$ 7,5 mm, cocas proeminentes, pubescentes, columela não observada. Sementes ca. $3 \times 3 \mathrm{~mm}$, esféricas, rugosas.
Material examinado: Distrito de São Domingos, Fazenda São Domingos, 10.XII.2009, fl. e fr., E. Melo 7420 (ALCB, HUEFS).

Distribuição: A espécie apresenta distribuição disjunta entre Madagascar e a América, onde tem ampla distribuição. No Brasil ocorre em todas as regiões com exceção da região Sul (BFG 2015).

Comentários: Dalechampia scandens pode ser reconhecida por apresentar brácteas involucrais alvas e estiletes dilatados no ápice. Na SGLA, a espécie é encontrada em fitofisionomia de ecótono entre caatinga e cerrado.

6.2 Dalechampia peckoltiana Müll. Arg., Fl. bras. 11(2): 647. 1874.

Trepadeiras, ramos não viscosos, pubescentes. Limbos papiráceos a membranáceos, 3-palmatilobados, lobos centrais 5,2-7,8 $\times 2-3,1$ $\mathrm{cm}$, elípticos, lobos laterais 4,8-7,3 × 1,8-3,1 cm, elípticos, venação actinódroma, ápice acuminado, margem inteira a levemente serrulada, eglandulosa, base cordada, face adaxial glabrescente, face abaxial pubescente, ambas com tricomas tectores, face abaxial verde; estipelas $0,8-10 \times 0,5 \mathrm{~mm}$, ovadas; pecíolos 3,5-6,3 cm compr.; estípulas $3,8-6,2 \times 1,5-2,3 \mathrm{~mm}$, lanceoladas, margem inteira. Inflorescências axilares; brácteas involucrais 5,8-6,2 × 4,9-5,2 cm, 3-lobadas, lobos 5,6-6,2 × 2,1-4,8 mm, margem serrulada, base arredondada a truncada, verde-claras; estípulas das brácteas 14,2$18 \times 5,4-7,5 \mathrm{~mm}$, ovadas a lanceoladas; brácteas masculinas $4,5,1-8,7 \times 6,5-7,7 \mathrm{~mm}$, circulares e côncavas; bractéolas resiníferas 5,6 × 4,3 mm, largo-oblongas, ápice fimbriado; brácteas femininas 
2, 5,6 $\times 4,9 \mathrm{~mm}$, largo-ovadas e flabeliformes, margem com glândulas. Flores estaminadas 10-12, 9,1-14 mm compr., bractéolas $10 \times 2-4 \mathrm{~mm}$, oblongas, ápice ciliado a lacerado; pedicelos 2,47,7 mm compr.; sépalas 3, 2,6-3,6 × 2,6-3,4 mm, esféricas a largo-ovadas, glabrescentes; estames numerosos, glabrescentes. Flores pistiladas 3, 2-2,1 cm compr., pedicelos 1-1,6 mm compr.; sépalas 3-3,5 $\times 1 \mathrm{~mm}$, lanceoladas, livres, face abaxial puberulenta, um par de glândulas na base; ovários ca. $2 \times 3 \mathrm{~mm}$, elipsoides, lóculos proeminentes, puberulentos; estilete estreito no ápice, 1,6-1,7 cm compr. Frutos $0,7 \times 1,2 \mathrm{~cm}$, cocas proeminentes, glabros, columelas nãos vistas. Sementes ca. $4 \times 3$ $\mathrm{mm}$, esféricas, lisas ou manchadas.

Material examinado: Serra do Jambeiro, 10.XII.2009, fl., M.L. Guedes 16794 (ALCB, HUEFS). Distrito de São Domingos, Fazenda São Domingos, 10.XII.2009, fl., E. Melo 7417 (ALCB, HUEFS).

Material adicional examinado: BRASIL. BAHIA: Cruz das Almas, Mata do Instituto, 11.IX.1983, fl. e fr., M.L. Guedes 842 (ALCB).

Distribuição: Endêmica do Brasil, a espécie tem registro para os estados da Bahia e Rio de Janeiro (Webster \& Armsbruster 1991; BFG 2015).

Comentários: Dalechampia peckoltiana pode ser reconhecida pelo tamanho das brácteas involucrais com cerca de $6 \mathrm{~cm}$ de comprimento e ápice dos estiletes estreitos. Na SGLA, a espécie é encontrada em fitofisionomia de ecótono entre caatinga e cerrado.

7. Euphorbia L., Sp. P1. 1: 450. 1753.

Ervas, subarbustos, arbustos e árvores, monóicas; indumento glabro ou com tricomas tectores; látex presente. Folhas alternas, ou opostas a verticiladas, limbo inteiro, estipuladas; glândulas ausentes na base do limbo; estípulas presentes, unidas na base ou livres, não glandulares. Inflorescências axilares ou terminais, pseudantos do tipo ciátio; brácteas conspícuas ou incospícuas. Flores estaminadas aclamídeas, reduzidas a um único estame. Flor pistilada aclamídea, solitária no centro do ciátio; ovário trilocular; estiletes inteiros ou bífidos. Fruto cápsula septicida e loculicida, com indumentos variados, columela persistente. Sementes de formatos variados, com ou sem carúncula.

Euphorbia L. é o maior gênero de Euphorbiaceae, com cerca de 2.000 espécies, e o quinto maior entre as Angiospermas. É um gênero cosmopolita e no Brasil existem 63 espécies, sendo cerca de 50\% endêmicas (Radcliffe-Smith 2001; BFG 2015). O gênero é monofilético e possui como sinapomorfia a inflorescência em pseudanto do tipo ciátio (Horn et al. 2012; Dorsey et al. 2013). Na SGLA, está representado por cinco espécies.

\section{Chave de identificação das espécies de Euphorbia da SGLA.}

1. Ervas ou arbustos $0,15-0,5 \mathrm{~m}$ alt., ou ervas prostradas; ciátios $1-4,2 \mathrm{~mm}$ diâm.; apêndices petaloides.

2. Ervas prostradas ou arbustos decumbentes; ovários pubescentes a setosos, ou lanosos.

3. Ervas prostradas; apêndices desiguais, glabros; ciátios solitários; flores estaminadas 12 por ciátio 7.1. E. adenoptera

3'. Arbustos decumbentes; apêndices iguais, pubescentes; ciátios em dicásio; flores estaminadas $28-36$ por ciátio. 7.6. E. setosa

2'. Ervas eretas; apêndices glabros; ovários glabros.

4. Venação actinódroma; limbos oblongos a oblanceolados, margem serrulada, base oblíqua; apêndices reflexos; bractéolas inteiras; 10-17 flores estaminadas; estiletes inteiros.

7.3. E. hyssopifolia

4'. Venação cladódroma; limbos lineares a estreito-oblongos, margem inteira, base simétrica, arredondada; apêndices eretos; bractéolas profundamente partidas; 26-28 flores estaminadas; estiletes 2 -fidos 7.4. E. potentilloides

1'. Arbustos 0,7-3 m alt.; ciátios 6-7,5 mm diâm.; apêndices lineares ou fimbriados.

5. Planta áfila; sinflorescências de ciátios glomérulos laterais; 5 glândulas; apêndices lineares e curvados; bractéolas profundamente partidas.... 7.2. E. attastoma

5'. Planta com folhas; sinflorescência de ciátios umbelas compostas terminais; 4 glândulas; apêndices fimbriados e retos; bractéolas lineares 7.5. E. sarcodes 
7.1 Euphorbia adenoptera Bertol. Misc. Bot. 3: 20. 1844.

Erva prostrada; látex alvo; ramos não viscosos, castanhos, viloso. Folhas opostas, limbos papiráceos, 6,8-11 × 4,5-6,3 mm, ovados a elípticos, venação actinódroma, ápice agudo a mucronado, margem serrulada, glandulosa, base oblíqua, face adaxial e abaxial glabrescente, ambas com tricomas tectores, face abaxial esverdeada; pecíolos 0,9-1,2 mm compr.; estípulas $1,7-1,9 \times 0,7-0,9 \mathrm{~mm}$, lineares, margem ciliada com glândulas próximo à base. Ciátios solitários, terminais e axilares tardios, em ramos congestos; ciátios 1,3-1,8 mm diâm., pedúnculos $0,5-$ $0,7 \mathrm{~mm}$; brácteas na base presentes, $2-4,9 \times 0,8-2,8$ $\mathrm{mm}$, semelhantes às folhas; invólucros verde-claros, 1,8-2 mm compr., glândulas 4, vináceas; apêndices petaloides, reflexos, desiguais, duas menores flabeliformes, duas maiores assimetricamente flabeliformes, ápice truncado e sinuoso, glabros, alvos tornando-se vináceos; lobos das brácteas entre as glândulas triangulares; bractéolas presentes, lineares, incospícuas. Flores estaminadas 12 por ciátio, 1,7-2,2 mm compr.; pedicelos 1-1,2 mm compr. Flores pistiladas esverdeadas, 1,8-2,1 mm compr.; pedicelos 0,8-1 mm compr.; ovários $0,5-0,8 \times 0,6-0,8 \mathrm{~mm}$, globosos, pubescentes a setosos; estiletes unidos na base, 2-fidos, glabros. Frutos 1,3-1,5 × 1,2-1,5 mm, pubescentes a setosos, columelas inteiras. Sementes $1-1,3 \times 0,5-0,7 \mathrm{~mm}$, elipsoides, costeladas, carúncula ausente.

Material examinado: Fazenda Lameirão, 21.II.2014, fl. e fr., F. Hurbath 613 (ALCB).

Distribuição: A espécie ocorre do México à America do Sul, e no Brasil possui ampla distribuição em todas as regiões do país (Silva et al. 2014; BFG 2015)

Comentários: Euphorbia adenoptera pode ser reconhecida pelo hábito prostrado e por apresentar ciátios solitários. Além disso, os apêndices são desiguais e tornam-se vináceos. Na SGLA, a espécie é encontrada em fitofisionomia de caatinga antropizada.

7.2 Euphorbia attastoma Rizzini, Revista Brasil. Biol. 49: 987. 1989 [1990]. $\quad$ Fig. 4a-g

Arbustos eretos ou decumbentes, ca. 1-3 $\mathrm{m}$ alt.; látex alvo a creme; ramos não viscosos, verdes a levemente cinéreos, carnosos, cactiformes, 6-costados, 1-1,2 cm diâm., glabros; depósito de cera espesso, amarelado, cicatrizes dos estômatos presentes. Áfilos. Sinflorescências de ciátios glomérulos, laterais; ciátios 6-7 mm diâm., sésseis; brácteas presentes na base do invólucro, $1-1,1 \times$ 1,5-2 mm, depresso-ovadas; invólucros verdes ou vináceos, 2,7-3,5 mm compr.; glândulas 5, verdes; com 2 apêndices, iguais, lineares, curvados, glabros, esbraquiçados; lobos das brácteas entre as glândulas flabeliformes; bractéolas presentes, profundamente partidas, ca. 2,5-3 mm. Flores estaminadas 0,5-2 mm compr, 12-16 por ciátio, $0,5-2 \mathrm{~mm}$ compr., subsésseis a pediceladas, $0,1-0,8 \mathrm{~mm}$ compr. Flores pistiladas verdes, 6-6,7 mm compr.; pedicelos 2,5-3 $\mathrm{mm}$ compr.; ovários 1,8-2 × 1,7-2 mm, globosos, glabros; estiletes unidos na base, inteiros, glabros. Frutos $4 \times$ $5 \mathrm{~mm}$, glabros, columelas inteiras. Sementes 2,3-3 $\times$ 1,8-2,5 mm, esféricas, carúnculas presentes.

Material examinado: Garimpo das Ametistas, 29.X.2012, fl. e fr., F. Hurbath 410 (ALCB). Mata ao lado da Caixa d'água, trilha Lameirão-Cachoeirão, 6.IV.2013, fl. e fr., $F$. Hurbath 510 (ALCB). Garimpo dos Areiões, 25.V.2013, fl. e fr., F. Hurbath 580 (ALCB).

Distribuição: A espécie é endêmica do Brasil e referida somente para o estado de Minas Gerais (BFG 2015). É aqui registrada pela primeira vez para o estado da Bahia. Além das coletas na SGLA, há uma coleta para a Serra Geral do município vizinho, Caetité (M.L. Guedes 14332 (ALCB)).

Comentários: Euphorbia attastoma é semelhante a E. phosphorea Mart. pelos ramos áfilos, verdes e ciátios similares, diferindo desta por apresentar ramos 6 costados ( $v s .8-10$ costados). $\mathrm{Na}$ SGLA, a espécie é encontrada em caatinga sobre afloramentos rochosos.

7.3 Euphorbia hyssopifolia L., Syst. Nat. 2: 1048. 1759.

Ervas eretas, ca. $0,5 \mathrm{~m}$ alt.; látex alvo; ramos não viscosos, vináceos, esparso-hirsuto, tricomas tectores. Folhas opostas, limbos papiráceos a membranáceos, 1,5-2,8 × 0,5-1,1 cm, oblongos a oblanceolados, venação actinódroma, ápice agudo a mucronado, margem serrulada, eglandulosa, base oblíqua, face adaxial e abaxial glabra, face abaxial esverdeada; pecíolos 1,2-2,1 mm; estípulas 0,6-0,7× 0,9-1,1 mm, largo-ovadas, margem lacerada a ciliada. Sinflorescências de ciátios dicásios, terminais; ciátios 1-1,6 mm diâm., pedúnculos 1-2,4 mm compr.; brácteas na base ausentes; invólucros verde-claros, 1,5-1,6 mm compr., glândulas 4, amarelas; apêndices petaloides, reflexos, iguais, largo-obovados, ápice arredondado, glabros, cremes; lobos das brácteas entre as glândulas triangulares; bractéolas presentes, inteiras, 1-1,2 $\mathrm{mm}$. Flores estaminadas $1,2-1,8 \mathrm{~mm}$ compr., $10-17$ por ciátio, 1,2-1,8 mm compr.; pedicelos 1-1,2 mm compr. Flores pistiladas verdes, 1,8-2,4 mm compr.; pedicelos $0,7-1 \mathrm{~mm}$ compr.; ovários $0,5-0,7 \times$ 


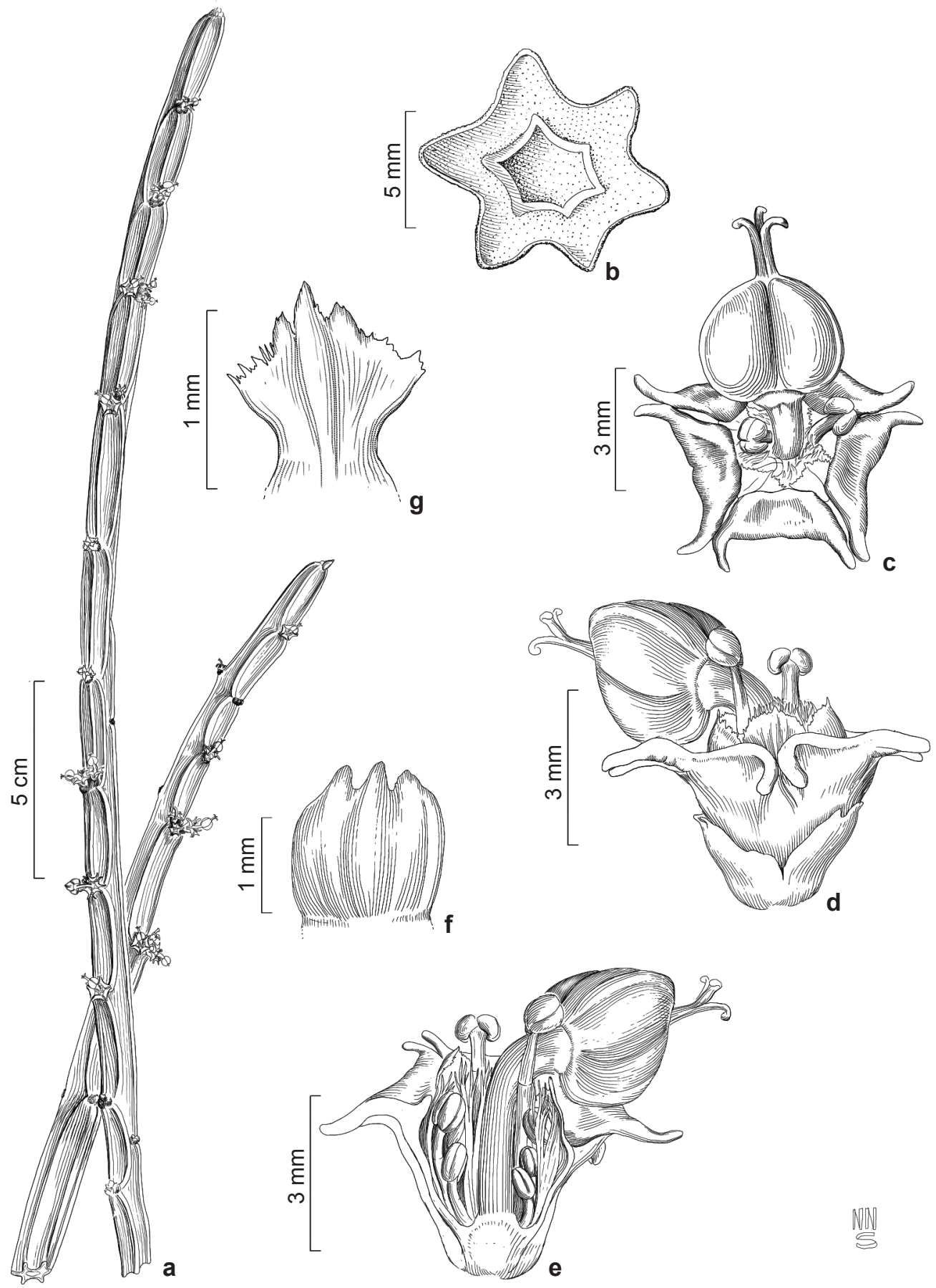

Figura 4 - a-g. Euphorbia attastoma - a. ramo fértil; b. corte transversal do ramo; c. glândulas do ciátio e apêndices; d. vista lateral do ciátio; e. corte longitudinal do ciátio; f. bráctea da base do invólucro; g. lobo da bráctea do invólucro. (a-g. F. Hurbath 222/410).

Figure 4 - a-g. Euphorbia attastoma - a. flower branchs; b. cross section of the branch; c. cyathium glands and appendices; d. lateral view of the cyathium; e. longitudinal section of the cyathium; f. bract of the base of cyathium; g. lobe of bracts of involucre. (a-g. F. Hurbath 222/410). 
0,3-0,5 mm, globosos, glabros; estiletes unidos na base, inteiros, glabros. Frutos 2,1-2,6 × 2,4-2,8 $\mathrm{mm}$, glabros, columelas inteiras. Sementes ca. 1,2 $\times$ $0,8 \mathrm{~mm}$, ovoides a elipsoides, carúnculas ausentes. Material examinado: Trilha para o Cachoeirão, 06.IV.2013, fl. e fr., F. Hurbath 513 (ALCB).

Distribuição: A espécie distribui-se na China e amplamente na América (tropicos.org 2014). No Brasil, abrange todas as regiões geográficas (BFG 2015).

Comentários: Euphorbia hyssopifolia assemelha-se a $E$. potentilloides, por serem ervas eretas, com ramos vináceos e apêndices petaloides. Diferencia-se por apresentar folhas actinódromas com margem serreada ( $v s$ folhas cladódromas com margem inteira em $E$. potentilloides), bractéolas das flores profundamente partidas e apêndices reflexos ( $v s$ bractéolas lineares e apêndices eretos). $\mathrm{Na}$ SGLA, a espécie é encontrada em fitofisionomia de caatinga antropizada.

\subsection{Euphorbia potentilloides (Boiss) Croizat, Cent.} Euphorb. 3. 1860.

Ervas eretas, ca. 0,15-0,33 m alt.; látex alvo; ramos não viscosos, vináceos, glabros. Folhas opostas a verticiladas, limbos papiráceos, 1,3-3,7 × 0,2-0,4 cm, lineares a estreito-oblongos, venação cladódroma, ápice agudo a acuminado, com mucro, margem inteira, eglandulosa, base arredondada, face adaxial e abaxial glabra, face abaxial esverdeada; pecíolos 0,5-1,4 mm compr.; estípulas $0,6-1 \times 0,7-0,9 \mathrm{~mm}$, ovadas, margem lacerada a fimbriada. Sinflorescências de ciátios dicásios, terminais e axilares; ciátios 1,6-2,1 mm diâm., pedúnculos 0,7-1,4 mm compr., brácteas na base ausentes; invólucros verde-claros, 1,9-2,7 mm compr., glândulas 4, amareladas; apêndices petaloides, eretos, iguais, obovados, ápice obtuso a truncado, glabros, alvos; lobos das brácteas entre as glândulas triangulares a ovadas; bractéolas presentes, profundamente partidas, 1,5-2 $\mathrm{mm}$ compr. Flores estaminadas 26-28 por ciátio, 2,2-3,1 mm compr.; pedicelos 1,7-2,1 mm compr. Flores pistiladas verdes, 3,5-4,6 $\mathrm{mm}$ compr.; pedicelos 2,3-3 mm compr.; ovários 1,1-1,7 × 1,4-1,8 mm, globosos, glabros; estiletes unidos na base, 2-fidos, glabros. Frutos 2,2-2,7 × 2,4-3 mm, glabros, columelas inteiras. Sementes 1,3-1,8 × 0,9-1,2 mm, ovoides, costeladas, carúncula ausente.

Material examinado: Saco da Onça, 28.X.2012, fl. e fr., F. Hurbath 306 (ALCB). Pedra Preta, 21.X.2013, fl. e fr., F. Hurbath 419 (ALCB). Subida na Pedra Preta, 21.X.2013, fl. e fr., F. Hurbath 426 (ALCB).
Distribuição: A espécie distribui-se na America do Sul (Simmons \& Hayden 1997), e no Brasil ocorre em todas as regiões, exceto na região Norte (BFG 2015).

Comentários: Euphorbia potentilloides pode ser reconhecida pelo limbo linear a estreitooblongo e apêndices das glândulas petaloides eretos. Ver comentários em E. hyssopifolia. $\mathrm{Na}$ SGLA, a espécie é encontrada em cerrado e cerrado de altitude, em solo pedregoso.

7.5 Euphorbia sarcodes Boiss., Cent. Euphorb. 29. 1860 .

Arbustos eretos, ca. 0,7-1 m alt.; látex alvo; ramos não viscosos, esverdeados, semisuculentos, glabros. Folhas alternas espiraladas, limbos papiráceos, 2,6-3,6 × 0,3-0,4 cm, lineares a estreito-espatulados, venação paralelódroma, ápice agudo a mucronulado, margem inteira, eglandulosa, base atenuada, face adaxial e abaxial glabras, face abaxial verde; subsésseis; estípulas não observadas. Sinflorescências de ciátios umbelas compostas, terminais; ciátios 6,5-7,5 mm diâm., brácteas na base presentes, 6,5-9,8 $\times$ 4,8-8,1 mm, largo-ovadas; invólucros vináceos, 3,5-4 mm compr.; glândulas 4, esverdeadas a castanhas; apêndices 3-7 fimbriados, retos, levemente desiguais, glabros, esbraquiçados; lobos das brácteas entre as glândulas obovadas; bractéolas presentes, inteiras, 1-1,8 mm compr. Flores estaminadas 12 por ciátio, 1,5-5,6 mm compr.; pedicelos 0,9-3,1 mm compr. Flores pistiladas verdes, ca. 5,8 mm compr.; pedicelos ca. 1,9 mm compr.; ovários ca. 1,1 × 0,9 mm, elipsoides, glabros; estiletes unidos $1 / 2$, inteiros, glabros. Frutos 3,1-3,4 × 3,7-4 mm, glabros, columelas inteiras. Sementes $2,1-2, \times 1,5-2 \mathrm{~mm}$, ovoides, carúncula ausente.

Material examinado: Estrada para Riacho de Areia, 27.X.2012, fl. e fr., F. Hurbath 303 (ALCB). Estrada para Riacho de Areia, 25.V.2013, fl. e fr., F. Hurbath 567 (ALCB).

Distribuição: A espécie é endêmica do Brasil, ocorre nos estados da Bahia, Pernambuco e Minas Gerais (BFG 2015).

Comentários: Euphorbia sarcodes pode ser reconhecida por apresentar ramos semi-suculentos, sinflorescência em umbelas compostas, apêndices dos ciátios fimbriados. Na área de estudo observou-se alguns indivíduos com ciátios com flor feminina vestigial ou atrofiada. $\mathrm{Na}$ SGLA, a espécie é encontrada em fitofisionomias de campos rupestres e cerrado. 
7.6 Euphorbia setosa (Boiss.) Müll. Arg., Fl. bras. 11(2): 672.1874.

Fig. 5a-f

Subarbustos decumbentes, ca. $0,2-0,3 \mathrm{~m}$ alt.; látex alvo; ramos não viscosos, entrenós bem marcados, castanhos, glabrescentes, dois tamanhos de tricomas tectores (curtos e longos). Folhas opostas dísticas, limbos papiráceos, 2-2,6 × 0,6$0,7 \mathrm{~cm}$, lanceolados, venação cladódroma, ápice agudo, margem inteira, eglandulosa, base obliqua, face adaxial e abaxial glabrescentes, ambas com tricomas tectores, face abaxial verde-amarelada; pecíolos 1,1-1,6 mm compr.; estípulas 1,2 × 0,4 $\mathrm{mm}$, estreito-triangulares, margem fimbriadoglandulosa. Sinflorescências de ciátios dicásios, terminais; ciátios 3-4,2 mm diâm., brácteas na base presentes, 3-4 × $1 \mathrm{~mm}$, lanceoladas; invólucros verde-claros, 2,3-3,4 mm compr.; glândulas 4, verde-amareladas; apêndices petaloides, eretos, iguais, convolutos, ápice truncado, pubescentes, amarelados; lobos das brácteas entre as glândulas triangulares; bractéolas presentes, profundamente partidas, ca. $2 \mathrm{~mm}$ compr. Flores estaminadas 28-36 por ciátio, 0,9-2,6 mm compr.; pedicelos $0,5-2 \mathrm{~mm}$ compr. Flores pistiladas verdes, 2,2-2,7 mm compr.; pedicelos 1,2-1,4 mm compr.; ovários $0,6-0,8 \times 0,5 \mathrm{~mm}$, globosos, lanosos; estiletes unidos na base, 2-fidos, glabros. Frutos 2,5-2,8 $\times 3,1-3,4 \mathrm{~mm}$, glabrescentes, columelas inteiras. Sementes ca. $2 \times 1 \mathrm{~mm}$, ovoides a elipsoides, costeladas, carúncula ausente.

Material examinado: Saco da Onça, 28.X.2012, fl. e fr., F. Hurbath 307 (ALCB). Saco da Onça, 21.VII.2012, fl. e fr., N. Roque 3695 (ALCB).

Material adicional examinado: BRASIL. BAHIA: Jacaraci, Morro do Chapéu, 24.V.2013, fl. e fr., F. Hurbath 573 (ALCB).

Distribuição: A espécie é endêmica do Brasil, distribuindo-se nas regiões Sudeste e Centro-Oeste (BFG 2015). É aqui registrada pela primeira vez no Estado da Bahia.

Comentários: A espécie é reconhecida por apresentar ramos com entrenós bem marcados, apêndices das glândulas do ciátio convolutos, truncados e pilosos. Na SGLA, a espécie é encontrada em cerrado de altitude, em solo pedregoso.

8. Gymnanthes Sw., Prodr. 6: 95-96. 1788.

Gymnanthes é um gênero com centro de diversidade localizado na região neotropical, mas com algumas espécies ocorrendo na África e Ásia (Esser 2001). Gymnanthes possui cerca de 11 espécies, das quais sete ocorrem no Brasil (BFG
2015). Caracteriza-se por apresentar ramos com flores pediceladas e fruto longo-pedicelado, com pericarpo espesso. Na SGLA, está representado por uma única espécie, tratando-se de um novo táxon para gênero em processo de estudo para publicação.

\subsection{Gymnanthes sp.}

Arbustos a arvoretas eretos, 1,5-3,5 m alt., monoicos; látex não observado; ramos não viscosos, esfoliantes, glabros. Folhas alternas, limbos papiráceos, 2-4 × 1,5-3 cm, ovados, venação broquidódroma, ápice arredondado, margem inteira, eglandulosa, base obtusa a truncada, face adaxial e abaxial glabras, face abaxial glauca com glândulas espaçadas; pecíolos 2,6-5,5 mm compr.; estípulas caducas, não observadas. Inflorescências tirsos, terminais, 2,6-3,2 cm compr.; raque glabra; brácteas $0,5-0,8 \times 0,3-0,9 \mathrm{~mm}$, triangulares. Flores estaminadas amarelas, 1,4-3,3 mm compr.; 2 flores por bráctea; pedicelos $0,3-1,9 \mathrm{~mm}$ compr.; sépalas $0,5-0,7 \times 0,5-0,6 \mathrm{~mm}$, largo-ovadas, margem erosa a lacerada, glabras; estames $3,0,7-1,2 \mathrm{~mm}$ compr., glabros. Flores pistiladas verdes, 3,4-5,1 mm compr., glabras; pedicelos $2,1-3,3 \mathrm{~mm}$ compr.; sépalas $0,5-0,7 \times 0,5-1 \mathrm{~mm}$, largo-ovadas, unidas na base, glabras; ovários 5-6 × 4-5 mm, obovoides, glabros; estiletes 3 , unidos na base, glabros; superfície estigmática verrucosa. Frutos $8,3 \times 8,8 \mathrm{~mm}$, globosos, polos truncados, verdes, glabros; pedicelos 1,3-1,5 cm compr.. Sementes 4,3-5 × 3,4-3,5 mm, oblongas, carúncula presente, inconspícua.

Material examinado: Mata do Xaxá, 22.I.2013, fr., F. Hurbath 455 (ALCB). Mata do Xaxá, 5.III.2013, fl. e fr., F. Hurbath 486 (ALCB). Mata do Xaxá, 23.V.2013, fl., F. Hurbath 544 (ALCB).

Distribuição: Foram encontrados materiais desta espécie para outros municípios do estado da Bahia como Morro do Chapéu, Rio de Contas, Milagres, Caetité, Barra do mendes e Almadina.

Comentários: Gymnanthes sp. diferenciase das demais espécies congêneras que ocorrem no Brasil pelo caule esfoliante, limbo ovado, com ápice e base arredondado, margem inteira, e presença de glândulas na superfície laminar abaxial. Na SGLA, a espécie é encontrada em floresta estacional decidual, em solo argiloso.

\section{Manihot Mill., Gard. Dict. Abr. ed. 4. 1754.}

Subarbustos, arbustos, árvores ou lianas, monóicos, raro dióicos; indumento de tricomas tectores ou plantas glabras; látex presente. Folhas alternas, limbo inteiro a lobado, estipuladas; 


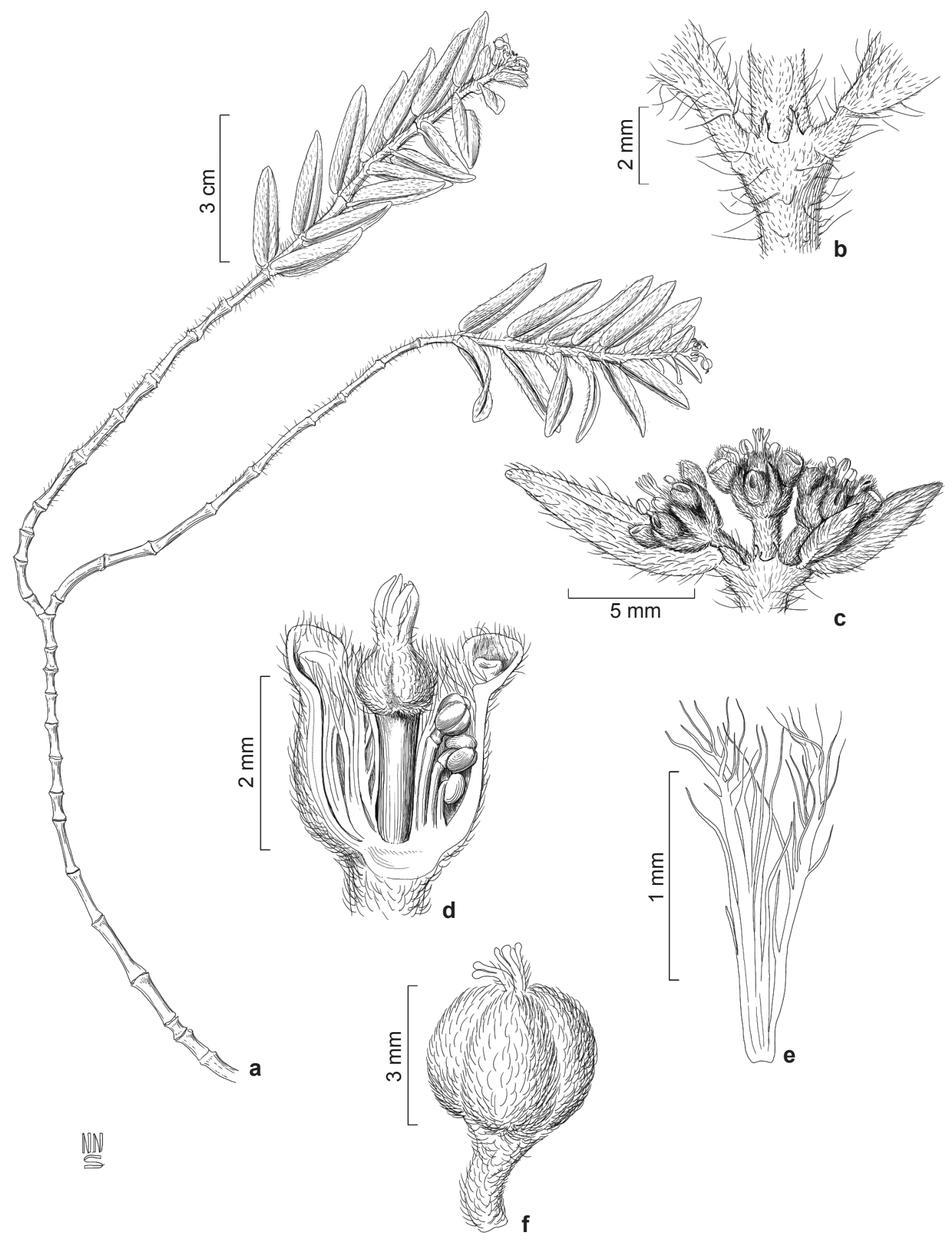

Figura 5 - a-f. Euphorbia setosa - a. ramo fértil; b. estípulas; c. inflorescência; d. corte longitudinal do ciátio; e. bractéola da flor estaminada; f. fruto. (a-f. F. Hurbath 307).

Figure 5 - a-f. Euphorbia setosa - a. flower branch; b. stipules; c. inflorescence; d. longitudinal section of the cyathium; e. bracteole of the staminate flower; f. fruit. (a-f. F. Hurbath 307). 
glândulas ausentes na base do limbo. Inflorescências terminais ou axilares, racemos ou panículas; brácteas conspícuas ou inconspícuas, às vezes foliáceas. Flores estaminadas monoclamídeas; sépalas unidas até $1 / 2$ ou $1 / 3$ de compr.; disco nectarífero inteiro; estames 10 , em dois ciclos. Flores pistiladas monoclamídeas, sépalas livres, 5; disco nectarífero geralmente inteiro; ovário trilocular; estiletes multífidos. Frutos cápsulas septicidas, lisas ou costadas, columela persistente. Sementes com carúncula séssil.
É um gênero neotropical com 100 espécies. O centro de diversidade está no Brasil, onde ocorrem 72 espécies (Rogers \& Appan 1973; RadcliffeSmith 2001). Caracteriza-se por apresentar folhas com limbo frequentemente lobado, presença de látex, raízes comumente tuberosas, inflorescências terminais, com flores monoclamídeas, geralmente gamossépalas, presença de um disco nectarífero conspícuo nos dois tipos de flores, estames geralmente 10, dispostos em dois ciclos. Na SGLA, está representado por três espécies.

\section{Chave de identificação das espécies de Manihot da SGLA}

1. Ramos com tricomas tectores; face adaxial do limbo glabrescente, junção dos lobos 1-1,5 mm compr.; brácteas foliáceas 9.1. M. caerulescens

1'. Ramos glabros; face adaxial do limbo glabra, junção dos lobos 16-31 mm compr.; brácteas paleáceas ou coriáceas.

2. Arbustos ca. 1,8 m. de alt.; limbos membranáceos, nervuras amareladas a castanhas; inflorescências panículas, raque glabra; brácteas paleáceas, 4-8,2 × 1,8-3 mm, elípticas a oblongas; Flores estaminadas azuladas com lobos amarelados, botões obovoides. 9.2. M. carthagenensis

2'. Arbustos ca. 0,5-1 m. de alt.; limbos papiráceos, nervuras vináceas; inflorescências racemos, raque glabrescente; brácteas coriáceas, 0,7-1,3 × 0,4-0,9 mm, ovadas; flores estaminadas amarelas, botões elipsoides 9.3. M. aff. sparsifolia

9.1 Manihot caerulescens Pohl, Pl. Bras. Icon. Descr. 1: 56. 1827.

Arbustos eretos a arvoretas, ca. $2 \mathrm{~m}$ alt., monoicos; látex amarelado; ramos não viscosos, ferrugíneos, puberulentos, tricomas tectores. Folhas alternas, limbos papiráceos, 5 (3)-lobado, lobo semelhantes entre si, 3,9-4,8 × 2,2-2,7 cm, obovados, venação broquidódroma, nervuras amareladas a castanhas, ápice apiculado, margem inteira, eglandulosa, base 2,2-2,4 mm larg., junção dos lobos 1-1,5 mm compr., sem sobreposição, face adaxial glabrescente, com tricomas tectores, face abaxial glabra, verde-clara; pecíolos 2,7-5,9 cm compr., alaranjados; estípulas 5,8-8,4 mm compr., lineares. Inflorescências racemosas terminais, decumbentes, 9,1-11,7 cm compr.; raque pubescente; brácteas inteiras, foliáceas, 2,6-1,6 $\times$ 0,8-1,1 cm, ovadas a elípticas. Flores estaminadas amarelas, 2,3-2,6 cm compr.; pedicelos 5,5-6,2 mm compr.; sépalas 5 , unidas $1 / 3$ inferior; lacínias $11 \times 3,8-7,4 \mathrm{~mm}$ triangulares a ovadas; disco nectarífero amarelo; botões ovoides a cônicos. Flores pistiladas amarelas, 2-2,4 cm compr.; pedicelos 5,5-9,8 mm compr.; sépalas 5, unidas na base; lacínias 13-13,2 × 4-5,2 mm, estreitotriangulares a lanceoladas; ovários 4,1-5,3 $\times$
3,5-3,6 mm, globosos, pubescentes; estiletes 3, unidos; disco nectarífero amarelo, estaminódios 5 ; botões ovoides a cônicos. Frutos 2,9 × 2,4 cm, glabros, castanho-escuros, com costelas irregulares, assemelhando-se à rugosidade, columela não observada. Sementes ca. 1,5 × 1,2 cm, largoovadas, cor-de-caramelo com máculas castanhas. Material examinado: Garimpo das Ametistas, 29.X.2012, fl. e fr., F. Hurbath 412 (ALCB).

Distribuição: A espécie ocorre no Paraguai (Rogers \& Appan 1973) e no Brasil, onde apresenta ampla distribuição (BFG 2015).

Comentários: Manihot caerulescens é reconhecida pelo látex amarelado, folhas com limbo profundamente lobado, com lobos obovados, inflorescência decumbente, brácteas foliáceas e fruto com textura rugosa. Na SGLA, a espécie é encontrado apenas um único indivíduo em ambiente de caatinga sobre afloramento rochoso.

9.2 Manihot carthagenensis (Jacq.) Müll. Arg., Prodr. 15 (2): 1073. 1866.

Arbustos eretos, ca. 1,8 m alt., monoicos; látex não observado; ramos não viscosos, verdeacastanhados, glabros. Folhas alternas, limbos membranáceos, 3-5-lobados, lobos semelhantes 
entre si, 6,5-12,7 × 2,3-6,2 cm, obovados a oblanceolados, venação broquidódroma, nervuras amareladas a castanhas, ápice apiculado, margem inteira, eglandulosa, base 1,7-2,3 cm larg., junção dos lobos 16-23 mm compr., levemente sobrepostos, face adaxial e abaxial glabras, face abaxial verdeclara; pecíolos 9,4-13 cm compr., castanhos; estípulas não observadas, caducas. Inflorescências panículas, terminais, eretas, 2,5-7 cm compr.; raque glabra; brácteas inteiras, paleáceas, 4-8,2 $\times$ 1,8-3 mm, elípticas a oblongas. Flores estaminadas azuladas com lobo amarelados, 1-1,5 cm compr.; pedicelos 1,8-2,1 mm compr.; sépalas 5, unidas ca. 2/3 compr. inferior; lacínias 3,5-4,7 × 3,8-7,4 $\mathrm{mm}$ triangulares a largo-triangulares, ou ovadas; disco nectarífero amarelo; botões obovoides. Flores pistiladas, frutos e sementes não observados.

Material examinado: Caminho para Rio Fundo, 15.X.2014, fl., M.L. Guedes 22584 (ALCB).

Distribuição: Distribui-se na Argentina, Paraguai, Bolívia, Venezuela, Colombia e Trinidad Tobago (Rogers \& Appan 1973). No Brasil, ocorre na região Nordeste (Mueller 1873) e Norte do Brasil, e em Minas Gerais (BFG 2015).

Comentários: Manihot carthagenensis difere das demais espécies do gênero que ocorrem na SGLA por apresentar limbo membranáceo e inflorescências em panículas com brácteas paleáceas. A espécie é utilizada no melhoramento da mandioca (Manihot esculenta Crantz) proporcionando às cultivares maior resistência a ambientes áridos (Rogers \& Appan 1973). Na SGLA, foi coletada em fitofisionomia de caatinga.

9.3 Manihot aff. sparsifolia Pohl, Pl. Bras. Icon. Descr. 1: 26-27. 1827.

Fig. 6a-f

Arbustos eretos, ca. 0,5-1 m alt., monoicos; látex esbranquiçado; ramos não viscosos, alaranjados quando jovens, glabros. Folhas alternas, peltadas, limbos papiráceos, 3 (4-5) lobado, lobos semelhantes, 3,4-8,7 × 1,7-5,3 cm, elípticos, venação actinódroma, nervuras vináceas, ápice mucronado, margem inteira, eglandulosa, base 1,7-5,4 cm larg., junção dos lobos 12,6-31 mm compr., sem sobreposição, face adaxial e abaxial glabras, face abaxial verde a levemente glauca; pecíolos 2,7-8,7 cm compr., vináceos; estípulas inteiras, lanceoladas, ca. 1,5 mm compr., caducas. Inflorescências racemos, terminais, eretos, todas partindo de um único ponto, 1,5-3,4 cm compr.; raque glabrescente; brácteas inteiras, coriáceas, 0,7-1,3 × 0,4-0,9 mm, ovadas. Flores estaminadas amarelas, 6,6-9,1 mm compr.; pedicelos 1,4-2 mm compr.; sépalas 5 , unidas até a metade; lacínias 3,1-3,7 ×2-2,7 mm, triangulares; disco nectarífero amarelo; botões elipsoides. Flores pistiladas amarelas, 1,2-1,6 mm compr.; pedicelos 5,3-7,8 mm compr.; sépalas 5 , unidas $1 / 3$ inferior; lacínias 4,6-5,9 × 1,7-3 mm, estreito-triangulares; ovários 1,7-2,4 × 1,7-2,1 mm, globosos, glabros; estiletes 3, unidos; disco nectarífero amarelo; estaminódios ausentes; botões elipsoides. Frutos imaturos, glabros, verdes com linhas alvas, liso. Sementes não observadas.

Material examinado: Pedra Preta, 21.I.2013, fl. e fr., F. Hurbath 423 (ALCB). Pedra Preta, 24.XI.2013, fl. e fr., F. Hurbath 590 (ALCB).

Distribuição: Nos herbários visitados foram encontradas apenas coletas provenientes do estado de Goiás.

Comentários: Manihot aff. sparsifolia difere de Manihot sparsifolia por apresentar folhas peltadas ( $v s$. não peltadas), limbo sagitado ( vs. limbo hastado), inflorescências menores do que $4 \mathrm{~cm}$ compr. ( $v s$. inflorescência com ca. $15 \mathrm{~cm}$ compr.), flores estaminadas com sépalas unidas até a metade e femininas com $1 / 3$ de união ( $v s$. flores estaminadas unidas $1 / 3$ e femininas partidas até a base). $\mathrm{Na}$ SGLA, a espécie é encontrada apenas na localidade de Pedra Preta, em fitofisionomia de cerrado.

10. Maprounea Aubl., Hist. Pl. Guiane 2: 895. 1775.

Ocorre nos neotrópicos e na África (Esser 2001) com quatro a cinco espécies, das quais três ocorrem no Brasil (Esser 2001; BFG 2015). Caracteriza-se por apresentar folhas com glândulas laminares na face abaxial do limbo, flores masculinas em um amentilho congesto, as femininas longopediceladas e isoladas na base ou em outra planta (Senna 1984). Na SGLA, está representado por uma espécie.

10.1 Maprounea brasiliensis A.St.-Hil., Pl. Usuel. Bras. t. 65. 1828.

Arbustos eretos, ca. 0,5-0,6 m. alt., monoicos; látex translúcido; ramos não viscosos, glabros. Folhas alternas, limbos papiráceos, 3,3-5,5 × 2,8-4,3 cm, largo-ovados, venação camptódromabroquidódroma, ápice arredondado a obtuso, ou acuminado, margem inteira, eglandular, base retusa, face adaxial e abaxial glabra, abaxial verde com glândulas próximas à base, 1-2 pares; pecíolos 5,3-7,6 mm compr.; estípulas inteiras, 0,9-1,2 × 0,7-1,1 mm, ovadas a largoovadas, margem inteira. Inflorescências laterais 

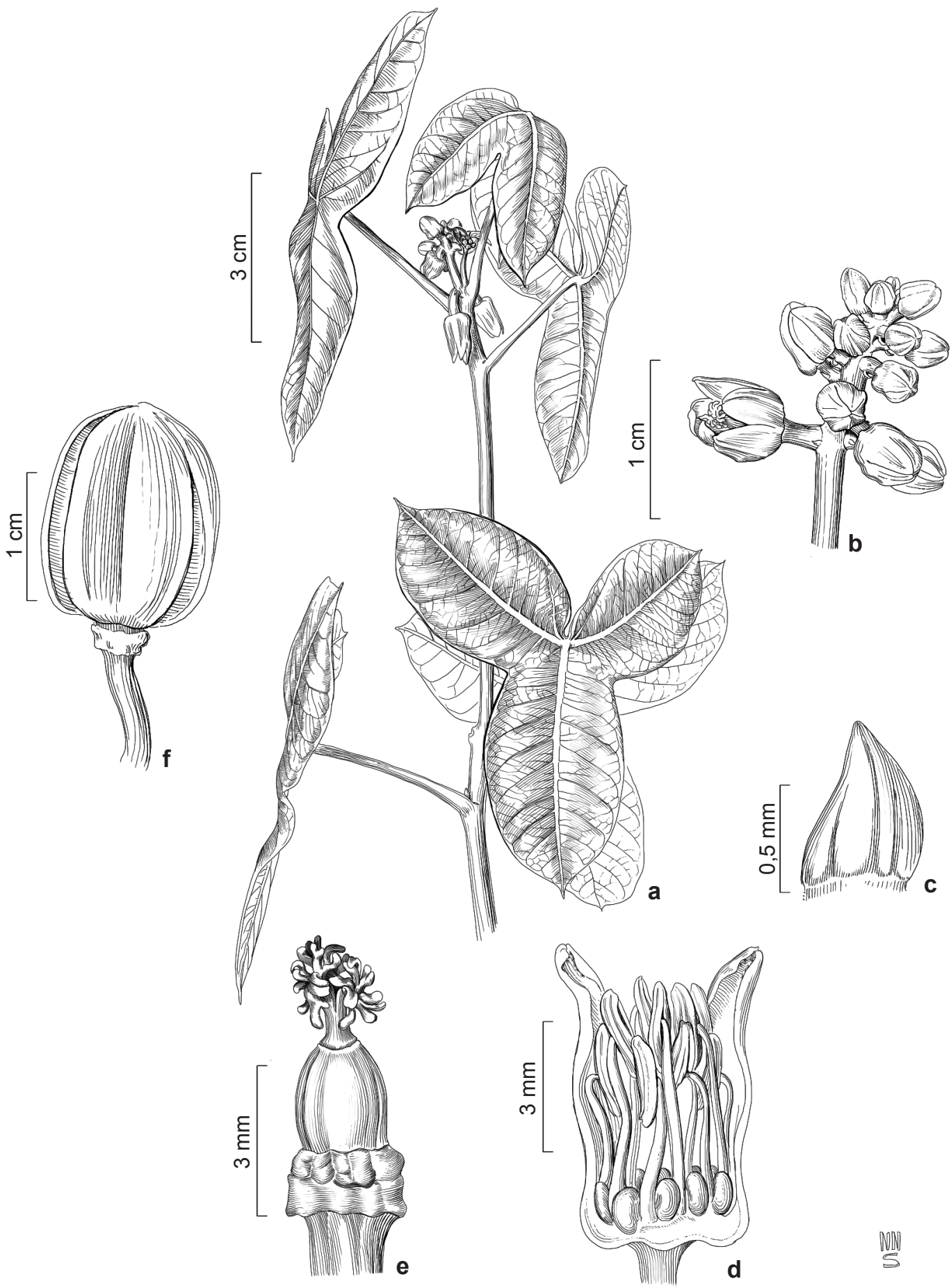

Figura 6 - a-f. Manihot aff. sparsifolia - a. ramo fértil; b. inflorescência; c. bráctea; d. flor estaminada com pétalas removidas, evidenciando os estames e o disco nectarífero; e. ovário e estiletes; f. fruto. (a-f. F. Hurbath 423/590). Figure 6 - a-f. Manihot aff. sparsifolia - a. flower branch; b. inflorescence; c. bract; d. staminate flower with petals removed, showing the stamen and nectary disk; e. ovary and styles; f. fruit. (a-f. F. Hurbath 423/590). 
e terminais, flores masculinas em tirsos globosos e flores femininas isoladas na base, 1,4-2,2 cm compr., glabra; brácteas 1,4-1,8 × 1,3-1,7 mm, triangulares, ápice caudado, 1 par de glândulas estipitadas na base. Flores estaminadas amarelas, 1,8-2,2 mm compr.; amentilhos com mais de 40 flores; brácteas 0,8-1 $\times 0,6-1,2 \mathrm{~mm}$, ovadas a triangulares, ápice longo-acuminado a caudado, margem fimbriada, um par de glândulas estipitadas na base; bractéolas membranáceas; subsésseis; sépalas 1,1-1,6 mm compr., gamossépalas, ápice recortado, glabras; estames 2, unidos ou separados, monadelfos. Flores pistiladas verdes, 6,3-11,2 mm compr.; pedicelos 1,8-6,1 mm compr.; sépalas 3, 1,2-1,7 × 1-1,2 mm, ovadas, unidas na base, ápice cuspidado, face abaxial glabra; ovários ca. 1,4 × 1,5 mm, globosos, glabros; estiletes 3 , unidos, glabros. Frutos $1 \times 1 \mathrm{~cm}$, globosos, glabros, pedicelos 1-1,7 cm. Sementes ca. $6 \times 5 \mathrm{~mm}$, obovoides, foveoladas, carúncula presente.

Material examinado: Cascarrento, 19.VII.2009, fl., $N$. Roque 3625 (ALCB). Saco da Onça, 21.VII.2012, fl., $N$. Roque 3697 (ALCB).

Material adicional examinado: BRASIL. BAHIA: Rio de Contas, Fazenda Brumadinho, Morro Brumadinho, 17.XI.1996, fl. e fr., N. Hind 4402 (ALCB).

Distribuição: Ocorre na Bolívia e no Brasil, com ampla distribuição (tropicos.org 2014; BFG 2015).

Comentários: Maprounea brasiliensis assemelha-se a $M$. guianensis Aubl. diferindo desta por ser um arbusto de pequeno porte, com limbo ovado a largo-ovado e brácteas das flores masculinas com ápice longo-acuminado a caudado (vs. hábito arbóreo, limbo elíptico e ápice das brácteas das flores masculinas agudo a acuminado). Além dos caracteres morfológicos, M. brasiliensis ocorre em habitat seco e $M$. guianensis em habitat úmido. Na SGLA, a espécie é encontrada em apenas duas localidades que apresentaram fitofisionomia de cerrado e cerrado de altitude.

11. Microstachys A. Juss., Euphorb. Gen. 48-49. 1824. Ervas a subarbustos, monoicos; indumento com tricomas tectores ou glabro; látex presente. Folhas alternas, limbo inteiro, estipuladas; glândulas ausentes na base do limbo. Inflorescências axilares e terminais, tirsos espiciformes com flores pistiladas na base da raque e flores estaminadas dispostas em címulas com 1-3 flores; brácteas inconspícuas com glândulas na base. Flores estaminadas monoclamídeas, sépalas livres, 3; estames 3, unidos na base. Flores pistiladas monoclamídeas, sépalas livres, 3; ovário trilocular; estiletes inteiros. Fruto cápsula septicida, glabro a tomentoso, columela persistente. Sementes com carúncula estipitada.

O gênero é pantropical com 15 espécies (Radcliffe-Smith 2001). O centro de diversidade está no Brasil onde ocorrem 14 espécies (Esser 2012; BFG 2015). Microstachys caracteriza-se pelo limbo com margem serreado-glandulosa (raro crenada), inflorescências opostas às folhas, frutos com cornículos e semente com carúncula discoide e estipitada (Esser 2001). Na SGLA, está representado por quatro espécies.

\section{Chave de identificação das espécies de Microstachys da SGLA}

1. Ramos glabros; limbos coriáceos; margem levemente crenulada; estípulas curto-fimbriadas; ovários glabros; frutos sem cornículos 11.4. M. uleana

1'. Ramos pubescentes a puberulentos, ou glabrescentes; limbos papiráceos; margem serrulada; estípulas inteiras; ovários puberulentos a glabrescentes; frutos com 2-10 cornículos por coca.

2. Margem do limbo sem glândulas (quando presentes, somente na porção inferior); sépalas das flores estaminadas obovadas a espatuladas; flores pistiladas subsésseis; sépalas das flores pistiladas com face abaxial pubérula a pubescente. 11.1. M. daphnoides

2'. Margem do limbo com glândulas; sépalas das flores estaminadas panduradas; flores pistiladas sésseis; sépalas das flores pistiladas com face abaxial glabrescente.

3. Arbustos bastante ramificados; margem dos limbos com serras adpressas a parcialmente adpressas; raque das inflorescências glabras a glabrescentes; sépalas das flores pistiladas elípticas a ovadas, ou obovadas a largo-obovadas, com $0-2$ glândulas na base, ou ausentes; ovários $0,6-0,8 \times 0,6-0,8$ $\mathrm{mm}$; frutos glabros com 2-6 cornículos por coca 11.2. M. glandulosa

3'. Arbusto pouco ramificado; margem dos limbos com serras não adpressas a parcialmente adpressas; raque das inflorescências puberulentas a hispidulosas, ou glabrescentes; sépalas das flores pistiladas largo-ovadas, com 2-4 glândulas na base; ovários 0,8-1,2 × 0,8-1,2 mm; frutos glabrescentes com 6-10 cornículos por coca 11.3. M. serrulata 
11.1 Microstachys daphnoides (Mart.) Müll. Arg., Linnaea 32: 91. 1863.

Arbustos eretos, pouco ramificado, ca. 0,8-2,5 m alt.; látex alvo; ramos não viscosos, pubescentes a puberulentos, tricomas tectores. Limbos papiráceos, 1,4-4,5 × 0,4-1,3 cm, ovados a lanceolados, venação broquidódroma, ápice agudo, margem serrulada, serras adpressas a parcialmente adpressas, eglandulosas (glândulas quando presentes, próximas à base, discoides), base arredondada, ou truncada a retusa, face adaxial glabrescente, face abaxial puberulenta, ambas com tricomas tectores, face abaxial verde; pecíolos 1,4-7,7 mm compr.; estípulas 0,5-1,3 mm compr., triangulares, margem inteira. Inflorescências 2-40 mm compr.; raque puberulenta a glabrescente; brácteas $0,3-0,7$ mm compr., triangulares; glândulas estipitadas. Flores estaminadas amarelas quando jovens e vermelhas quando maduras, $0,8-1,3 \mathrm{~mm}$ compr.; címulas com 1-3 flores; sésseis, sépalas $0,5-1 \times$ $0,1-0,4 \mathrm{~mm}$, obovadas a espatuladas, levemente panduradas. Flores pistiladas verdes, ca. $2 \mathrm{~mm}$ compr.; subssésseis; sépalas 1,1-2 × 0,4-0,7 $\mathrm{mm}$, ovadas, livres, face abaxial puberulenta a pubescente, glândulas na base $0-2$; ovários 0,8-1 × 0,8-1 mm, globosos, com cornículos, puberulentos; estiletes 3 , livres, puberulentos. Frutos 4-5,6 $\times 4-4,8 \mathrm{~mm}$, glabros a puberulentos, 4-5 cornículos por coca. Sementes 3-4,5 × 1,8-2 $\mathrm{mm}$, botuliformes.

Material examinado: Pedra Preta, 21.I.2013, fl. e fr., F. Hurbath 425 (ALCB). Saco da Onça, 5.IV.2013, fl. e fr., F. Hurbath 492 (ALCB). Trilha da Sete Quedas, 06.IV.2013, fl. e fr., F. Hurbath 519 (ALCB). Trilha da Sete Quedas, 06.IV.2013, fl. e fr., F. Hurbath 520 (ALCB). Trilha ao lado da Cachoeira das Sete Quedas, 22.V.2013, fl. e fr., F. Hurbath 540 (ALCB).

Distribuição: A espécie é endêmica do Brasil e amplamente distribuída no país (BFG 2015).

Comentários: Microstachys daphnoides caracteriza-se por apresentar ramos pubescentes a puberulentos, margem do limbo com serras adpressas a parcialmente adpressas, 4-5 cornículos por coca. Na SGLA, a espécie é encontrada em cerrado, cerrado de altitude e caatinga sobre afloramento rochoso.

11.2 Microstachys glandulosa (Mart. \& Zucc.) Esser \& M.J. Silva, Phytotaxa 32: 19. 2011.

Arbustos eretos, bastante ramificados, ca. 0,5-1 m alt.; látex alvo; ramos não viscosos, pubescentes a puberulentos, ou glabrescentes, tricomas tectores. Limbos papiráceos, 9,6-17 $\times 5,3-9 \mathrm{~mm}$, elípticos a ovados, venação broquidódroma, ápice arredondado a mucronado, margem serrulada, serras adpressas a parcialmente adpressas, com glândulas discoides, base arredondada a retusa, face adaxial glabrescente a glabra, face abaxial puberulenta a glabrescente, ambas com tricomas tectores, face abaxial verde; pecíolos $0,7-2,5 \mathrm{~mm}$ compr.; estípulas 0,4-0,8 mm compr., triangulares, margem inteira. Inflorescências 1,3-3,3 mm compr.; raque glabrescente a glabra; brácteas $0,3-0,7$ mm compr., triangulares; glândulas estipitadas. Flores estaminadas amarelas quando jovens e vermelhas quando maduras, $0,5-1,2 \mathrm{~mm}$ compr.; címulas com 1-3 flores; sésseis a subsésseis; sépalas $0,6-0,9 \times 0,2-0,4 \mathrm{~mm}$, panduradas. Flores pistiladas verdes, $1-1,8 \mathrm{~mm}$ compr.; sésseis; sépalas $0,5-1,1 \times 0,3-1 \mathrm{~mm}$; elípticas a ovadas, ou obovadas a largo-obovadas, livres, face abaxial glabrescente, glândulas na base $0-2$; ovários $0,6-0,8 \times 0,6-0,8 \mathrm{~mm}$, globosos com cornículos, glabrescentes; estiletes 3 , livres, glabros. Frutos 3,4-4,3 × 2,8-4 mm, glabros, 2-6 cornículos por coca. Sementes 3-3,5 × 1,5-2 $\mathrm{mm}$, botuliformes ou elipsoides.

Material examinado: Cachoeirão, 26.II.2012, fl. e fr., F. Hurbath 264 (ALCB). Curral do Estevão, 10.V.2012, fl. e fr., F. Hurbath 275 (ALCB). Trilha Xaxá-Cachoeirão, 23.I.2013, fl. e fr., F. Hurbath 460 (ALCB); Campo rupestre do Xaxá, 23.V.2013, fl. e fr., F. Hurbath 551 (ALCB).

Distribuição: A espécie é endêmica do Brasil e referida somente para Minas Gerais (BFG 2015). É aqui registrada pela primeira vez para o estado da Bahia.

Comentários: Microstachys glandulosa é facilmente reconhecida em campo por ser um arbusto densamente ramificado, onde as inflorescências espiciformes permanecem eretas, aparentando estar no ápice dos ramos. Na SGLA, a espécie é encontrada em campos rupestres.

11.3 Microstachys serrulata (Mart. \& Zucc.) Müll.Arg., Linnaea 32: 90. 1863.

Arbustos eretos, pouco ramificados, ca. $1 \mathrm{~m}$ alt.; látex alvo; ramos não viscosos, pubescentes a puberulentos, tricomas tectores. Limbos papiráceos, $1,4-3 \times 0,5-1,2 \mathrm{~cm}$, elípticos ou ovados a lanceolados, venação broquidódroma, ápice agudo ou arredondado, margem serrulada, serras não adpressas a parcialmente adpressas (raro); com glândulas 
discoides, base arredondada, face adaxial e abaxial puberulentas a glabrescentes, ambas com tricomas tectores, face abaxial verde; pecíolos 1,1-3,7 mm compr.; estípulas 0,5-1 $\mathrm{mm}$ compr., triangulares a ovadas, margem inteira. Inflorescências 1,3-3,6 cm compr.; raque puberulenta a hispidulosa, ou glabrescente; brácteas $0,1-1,3 \mathrm{~mm}$ compr., triangulares a ovadas; glândulas estipitadas. Flores estaminadas amarelas, 0,8-1 $\mathrm{mm}$; címulas 1-3 flores; subsésseis; sépalas $0,7-0,9 \times 0,2-0,4 \mathrm{~mm}$, panduradas. Flores pistiladas verdes, 1,3-2 mm compr.; sésseis; sépalas 0,5-1,2 × 0,4-0,9 mm, largo-ovadas, livres, face abaxial glabrescente, 2-4 glândulas na base; ovários $0,8-1,2 \times 0,8-1,2$ $\mathrm{mm}$, globosos com cornículos, glabrescentes; estiletes 3, livres, glabros. Frutos 4,3-6 × 3-5 mm, glabrescentes, 6-10 cornículos por coca. Sementes 2,5-4 × 1,5-2 mm, botuliformes.

Material examinado: São Domingos, 25.II.2012, fl. e fr., F. Hurbath 248 (ALCB). Cascarrento, 28.X.2012, fl. e fr., F. Hurbath 407 (ALCB). Pedra Preta, 21.I.2013, fl. e fr., F. Hurbath 422 (ALCB). Saco da Onça, 24.V.2013, fl. e fr., F. Hurbath 555 (ALCB).

Distribuição: A espécie ocorre no Brasil e Paraguai (Pscheidt \& Cordeiro 2012). No primeiro, a espécie ocorre nas regiões CentroOeste, Sudeste e Sul (BFG 2015) e este estudo representa o primeiro registro para o estado da Bahia.

Comentários: Microstachys serrulata caracteriza-se por possuir serras não adpressas, raro parcialmente adpressas, na margem do limbo e frutos com 6-10 cornículos por coca. $\mathrm{Na}$ SGLA, a espécie é encontrada em fitofisionomia de ecótono entre caatinga e cerrado.

11.4 Microstachys uleana (Pax \& K.Hoffm.) Esser, Kew Bull. 53: 959. $1998 . \quad$ Fig. 7a-i

Arbustos eretos, bastante ramificados, ca. 0,5-0,7 m alt.; látex alvo; ramos não viscosos, costados, glabros. Limbos coriáceos 1,9-3,2 × 1,1-2 cm, elípticos a ovados, ou largoelípticos, venação broquidódroma, ápice retuso a mucronulado, margem levemente crenulada, proeminente, eglandulosa (glândulas quando presentes, próximas à base), discoides, base arredondada a obtusa, ou retusa, face adaxial e abaxial glabra, face abaxial verde; pecíolos 2-4,1 mm compr.; estípulas $0,7-0,9 \mathrm{~mm}$ compr., ovadas, margem curto-fimbriada. Inflorescências 2,1-6,7 cm compr.; raque glabra; brácteas $0,5-1,1 \mathrm{~mm}$ compr., triangulares glândulas sésseis. Flores estaminadas verdes com estames amarelos e vináceos, 0,8-1,5 mm compr.; címulas 2-3 flores; sésseis, sépalas $0,5-1 \mathrm{~mm}$ compr., obovadas a largo-obovadas, unidas na base. Flores pistiladas verdes, 2-4 × 1-1,5 mm; sésseis; sépalas 0,8-1 $\times$ $0,8 \mathrm{~mm}$; largo-ovadas, livres, face abaxial glabra, glândulas na base 2 ; ovários $0,5-2 \times 0,7-2 \mathrm{~mm}$, globosos com cornículos, glabros; estiletes 3 , unidos na base, glabros. Frutos 3,9-5,9 × 3,6-6 $\mathrm{mm}$, glabros, cornículos por coca ausentes (pode apresentar pequenas saliências). Sementes 4-4,5 $\times 2 \mathrm{~mm}$, botuliformes.

Material examinado: Pedra Preta, 21.I.2013, fl. e fr., F. Hurbath 427 (ALCB). Riacho de Areia, 21.I.2013, fl. e fr., F. Hurbath 431 (ALCB). Cascarrento, 22.I.2013, fl. e fr., F. Hurbath 440 (ALCB). Estrada para Riacho de Areia, 24.V.2013, fl. e fr., F. Hurbath 570 (ALCB).

Distribuição: A espécie é endêmica da Bahia (BFG 2015).

Comentários: Microstachys uleana pode ser reconhecida por ser totalmente glabra, apresentar ramos jovens achatados, folhas posicionadas de forma vertical, limbo com margem crenulada e frutos sem cornículos. Os indivíduos mais maduros apresentam hábito robusto, tratando-se de um arbusto ramificado com até $70 \mathrm{~cm}$ de altura. Na SGLA, a espécie é encontrada em cerrado, cerrado de altitude e campos rupestres.

12. Sebastiania Spreng., Neue Entdeck. Pflanzenk. 2: 118. 1820.

Arbustos a árvores, monóicas; indumento glabro; látex presente. Folhas alternas, limbo inteiro, estipuladas; glândulas ausentes na base do limbo. Inflorescências terminais, tirsos espiciformes com flores pistiladas na base da raque com flores estaminadas dispostas em címulas com 1-3 flores; brácteas inconspícuas com glândulas na base. Flores estaminadas monoclamídeas, sépalas unidas, 3-lobadas; estames 3, livres. Flores pistiladas monoclamídeas, sépalas livres ou unidas, 3; ovário trilocular; estiletes inteiros. Frutos cápsula septicida, glabro, columela persistente com ápice alado. Sementes com carúncula séssil.

O gênero é neotropical com ca. 25 espécies (Esser 2001), das quais nove ocorrem no Brasil (BFG 2015) que se caracterizam por serem plantas totalmente glabras, com flores sésseis a subsésseis, três sépalas e estames livres, frutos lisos, pericarpo delgado, sementes geralmente lisas e carúnculas aderentes (Esser 2001). Na SGLA, está representado por duas espécies. 


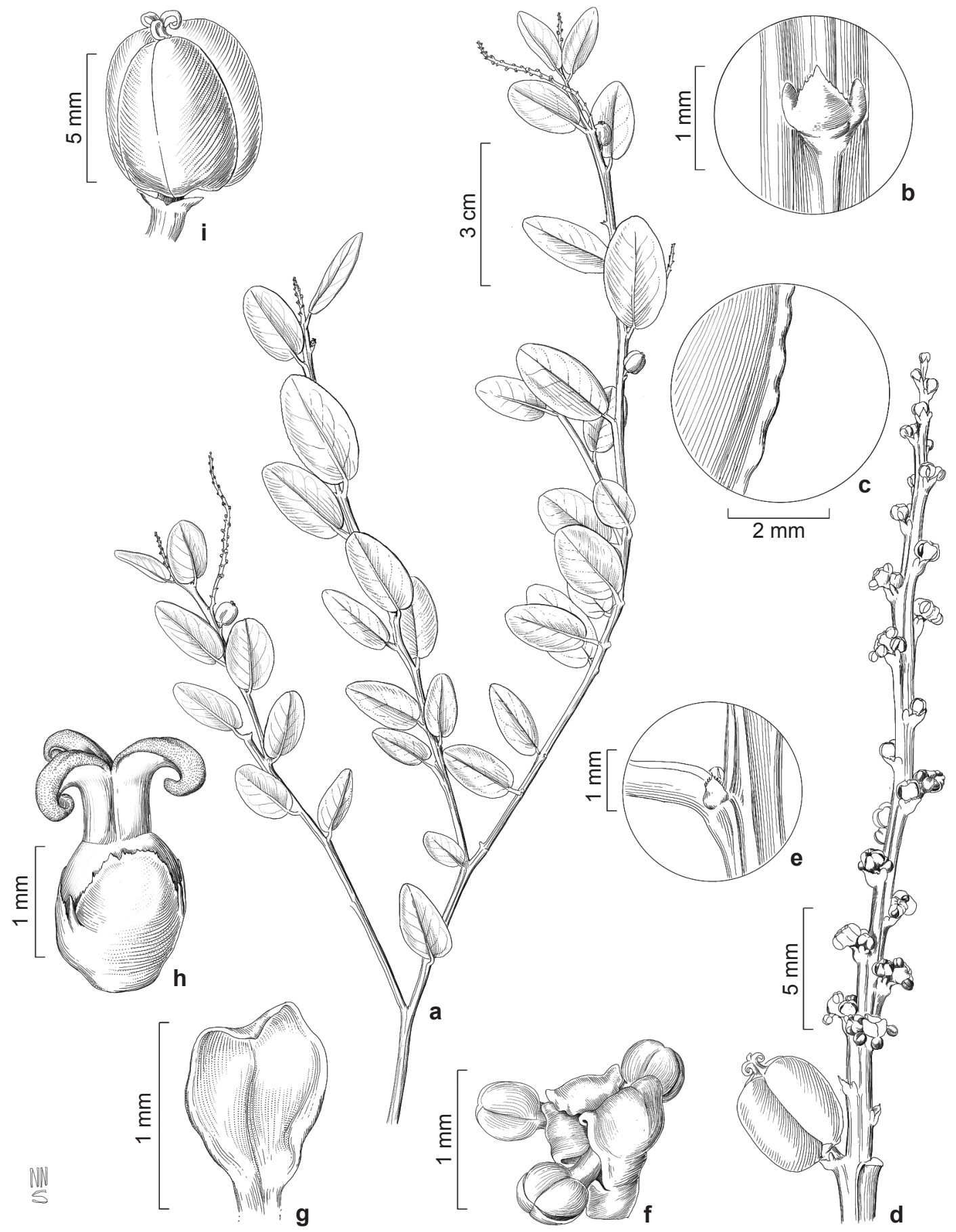

Figura 7 - a-i. Microstachys uleana - a. ramo fértil; b. brácteas com glândulas; c. detalhe da margem foliar; d. inflorescência; e. estípulas; f. flor estaminada; g. sépala estaminada; h. flor pistilada; i. fruto. (a-i. F. Hurbath 461). Figure 7 - a-i. Microstachys uleana - a. flower branch; b. bracts with glands; c. detail of the margin; d. inflorescence; e. stipules; f. staminate flower; g. sepal of staminate flower; h. pistillate flower; i. fruit. (a-i. F. Hurbath 461). 


\section{Chave de identificação das espécies de Sebastiania da SGLA}

1. Limbos largo-elípticos a largo-ovados, base obtusa a truncada, ou arredondada; glândulas na base das brácteas com superfícies lisas 12.1. S. brevifolia

1'. Limbos elípticos a obovados, ou largo-obovados, base aguda a atenuada; glândulas na base das brácteas com superfícies rugosas..... 12.2. S. catingae

12.1 Sebastiania brevifolia (Müll.Arg.) Müll. Arg., Prodr. 15(2): 1186. 1866

Arbustos eretos, ca. 1,5-1,8 m alt.; látex alvo; ramos não viscosos. Limbos papiráceos a membranáceos, $0,9-1,8 \times 0,6-1,3 \mathrm{~cm}$, largo-elípticos a largo-ovados, venação broquidódroma; ápice arredondado a obtuso, ou agudo, margem crenada a serrulada, eglandular, base obtusa a truncada, ou arredondada, face adaxial e abaxial glabra, face abaxial verde claro; pecíolos 3-8,4 mm compr.; estípulas $0,6-1,3 \mathrm{~mm}$ compr., profundamente partidas a fimbriadas. Inflorescências 1,2-1,5 cm compr.; raque glabra; brácteas 0,4-1,2 × 1-1,5 mm, largo-ovadas, ápice apiculado, margem denteada a recortada, glândulas na base 2, largo-elípticas, sésseis, superfície lisa. Flores estaminadas amarelas passando a róseas, 0,9-1,4 mm compr.; címulas com 1-2 flores; sésseis; sépalas filiformes, $0,5-0,9 \times 0,1$ $\mathrm{mm}$, glabras. Flores pistiladas esverdeadas, ca. 3,5 mm compr.; subssésseis; sépalas ovadas, $0,8-1,2 \times 0,5$ $\mathrm{mm}$, livres, glabras; glândulas ausentes; ovários ca. $0,9 \times 0,7 \mathrm{~mm}$, elipsoides, glabros; estiletes 3 , unidos na base, glabros. Frutos 5-6 × 6-7 mm, globosos, glabros, lisos, castanhos. Sementes não observadas. Material examinado: Trilha ao lado da Cachoeira Sete Quedas, 5.XI.2013, fl. e fr., F. Hurbath 597 (ALCB).Riacho Fundo, 5.XI.2013, fl. e fr., F. Hurbath 602 (ALCB).

Distribuição: A espécie é endêmica do Brasil distribuindo-se nas regiões Nordeste e Sudeste (Codeiro et al. 2014).

Comentários: Sebastiania brevifolia assemelhase a Sebastiania catingae diferindo desta por apresentar limbo largo-elíptico a largo-ovado, com base obtusa a truncada e glândulas discoides e lisas na base das brácteas (vs. limbo obovado, largo-obovado ou elíptico, com base aguda a atenuada e glândulas rugosas na base das brácteas, dando a impressão de muitas aglomeradas). Ver comentário de $S$. catingae. $\mathrm{Na}$ SGLA, a espécie é encontrada em fitofisionomia de caatinga sobre afloramento rochoso.

12.2 Sebastiania catingae Ule, Bot. Jahrb. Syst. 42(2-3): 222. 1908.

Arbustos eretos, ca. 0,5-2 m alt.; látex alvo; ramos não viscosos. Limbos papiráceos a membránaceos, $1-4,3 \times 0,8-2,9 \mathrm{~cm}$, obovados a largoobovados, ou elípticos; venação broquidódroma, ápice arredondado a obtuso, margem serrulada, levemente revoluta, eglandular, base aguda a atenuada, face adaxial e abaxial glabra, face abaxial verde clara; pecíolos 1,5-4,3 mm compr.; estípulas 0,4-1,2 $\mathrm{mm}$ compr., profundamente partidas a fimbriadas. Inflorescências 1,8-2,2 cm compr.; raque glabra; brácteas $1-1,2 \times 1,2 \mathrm{~mm}$, largo-depresso-ovadas, ápice apiculado, margem lacerada, glândulas na base 2, largo-elípticas, sésseis, superfície rugosa. Flores estaminadas vináceas, ca. 1,1 mm compr.; címulas com 2 flores; sésseis; sépalas profundamente partidas, fimbriadas, $1 \times 0,1-0,2 \mathrm{~mm}$, glabras. Flores pistiladas esverdeadas, 1,7-2,1 mm compr.; sésseis; sépalas obovadas, $1,3-2 \times 0,6-0,7 \mathrm{~mm}$, unidas na base, glabras; glândulas ausentes; ovários ca. 1,5-1,9 mm compr., elipsoides, glabros; estiletes 3 , unidos na base, glabros. Frutos $0,9-1 \times 1-1,1 \mathrm{~cm}$, glabros, lisos, castanhos, cocas angulosas. Sementes 4 4,3 $\times$ 2,7-3,5 mm, esféricas.

Material examinado: Lameirão, 11.V.2012, fl. e fr., $F$. Hurbath 286 (ALCB); 5.XI.2013, fl. e fr., F. Hurbath 595 (ALCB); 5.XI.2013, fl. e fr., F. Hurbath 596 (ALCB).

Distribuição: A espécie é endêmica da Bahia com registro para a localidade-tipo Tamburí. Este estudo apresenta dados inétidos sobre sua distribuição em outras localidades.

Comentários: No protólogo, esta espécie consta como semelhante ou intermediária à Sebastiania brevifolia e S. brasiliensis Spreng. Apesar de Ule descrever que $S$. catingae possui folhas oblongas, no estudo do material tipo (disponível em www.plants. jstor.org), não foram visualizadas folhas oblongas e sim folhas elípticas a obovadas. Ver comentários de Sebastiania brevifolia. Na SGLA, a espécie é encontrada em áreas de caatinga antropizadas, contudo, a cerca de $200 \mathrm{~m}$ de um afloramento rochoso com presença predominante de espécies de caatinga.

13. Stillingia Garden ex L., Syst. Nat. 2: 637. 1767.

Ervas, arbustos ou árvores, monóicas; indumento glabro; látex presente. Folhas opostas ou alternas, limbo inteiro, estipuladas, glândulas presentes ou ausentes na base do limbo. Inflorescências axilares 
e terminais, tirsos espiciformes geralmente com raque carnosa, com flores estaminadas dispostas em címulas com 3-23 flores; brácteas inconspícuas com glândulas na base. Flores estaminadas monoclamídeas, sépalas unidas, 2-lobadas; disco nectarífero ausente; estames 2, livres ou unidos na base. Flores pistiladas monoclamídeas ou aclamídeas; sépalas livres ou unidas, 3; ovário bi-trilocular; estiletes inteiros. Frutos cápsula septicida, com parte superior deiscente e parte inferior indeiscente, permanecendo na planta um carpidióforo, columela não persistente. Sementes com ou sem carúncula, quando presente séssil.

O gênero é quase totalmente neotropical, com 27 espécies (Esser 2001), das quais, nove ocorrem no Brasil (BFG 2015). Caracteriza-se por apresentar folhas e raque carnosas a semi-carnosas e presença de carpidióforo (ou ginobase, segundo Rogers 1951) persistente após a dispersão. Na SGLA, é representado por duas espécies.

\section{Chave de identificação das espécies de Stillingia da SGLA.}

1. Limbos rômbicos a angulado-ovados, com ápice acuminado, base decorrente sem glândulas, margem serreada; inflorescências 2,6-3,5 cm compr.; flores estaminadas alvas; címulas de flores masculinas com 5 flores, com bractéolas lineares; sépalas das flores pistiladas unidas; ovários piriformes .....

13.1. S. trapezoidea

1'. Limbos elípticos a estreito-elípticos, com ápice arredondado a mucronado, base atenuada com duas glândulas escuteliformes, margem crenada; inflorescências 5,8-10,2 cm compr.; flores estaminadas amarelas; címulas de flores masculinas com 8-22 flores, com bractéolas oblanceoladas; sépalas das flores pistiladas livres; ovários globosos..... 13.2. S. uleana

13.1 Stillingia trapezoidea Ule, Bot. Jahrb. Syst. 42: 223. 1908.

Arbustos eretos, ca. 1,5-3 m alt.; látex alvo; ramos não viscosos. Folhas alternas, limbos cartáceos, $3,8-5,7 \times 1,4-5,3 \mathrm{~cm}$, rômbicos a angulado-ovados, venação cladódroma a broquidódroma, ápice acuminado, margem serreada com glândulas subsésseis, cônicas, base decorrente, face adaxial e abaxial glabra, face abaxial verde; pecíolos 4,3-8,9 mm compr.; estípulas $0,7-1,1 \times 0,5-0,6 \mathrm{~mm}$, ovadas, margem inteira. Inflorescências 2,6-3,5 cm compr.; raque glabra; brácteas 1,9-2 × 2-2,5 mm, depressoovadas; glândulas discoides, sésseis a subsésseis. Flores estaminadas alvas, 2,3-3 mm compr., címulas 5 flores; bractéolas $1 \mathrm{~mm}$ compr., lineares; pedicelos 0,5-0,9 mm compr.; sépalas $0,8-1,1 \mathrm{~mm}$ compr., ápice arredondado, glabras. Flores pistiladas verdes com estigmas vináceos, 4-4,2 mm compr., sésseis; sépalas $1,1 \times 1,5 \mathrm{~mm}$, largo-obovadas, unidas, margem irregular, face abaxial glabra; ovários ca. 2,6 $\times 1,6 \mathrm{~mm}$, piriformes, glabros; estiletes 3 , unidos na base, glabros. Frutos, sementes e carpidióforos não observados.

Material examinado: Serra do Jambeiro, 4.XI.2006, fl., A. Rapini 1342 (HUEFS).

Distribuição: Segundo Rogers (1951) e BFG (2015), a espécie é endêmica do nordeste, ocorrendo nos estados do Piauí, Paraíba, Pernambuco e Sergipe. É aqui registrado pela primeira vez para o estado da Bahia.
Comentários: Stillingia trapezoidea é reconhecida por suas folhas pecioladas, com limbo rômbico ou angulado-ovado, margem com glândulas subsésseis cônicas e base decorrente. Na SGLA, a espécie é encontrada em fitofisionomia de cerrado.

\subsection{Stillingia uleana Pax. \& K. Hoffm., Pflanzenr.} IV. 147: 187. 1912.

Fig. 8a-j

Arbustos eretos, ca. 1-1,2 m. alt.; látex alvo; ramos não viscosos, angulosos, glabros. Folhas alternas, limbos cartáceos a semi-carnosos, 2,9-7,3 $\times 1,2-2,5 \mathrm{~cm}$, elípticos a estreito-elípticos, venação broquidódroma, ápice arredondado a mucronado, margem crenada com glândulas sésseis, discoides, base atenuada, pode apresentar 1-2 glândulas escuteliformes, face adaxial e abaxial glabra, abaxial verde; pecíolos 4,2-17,8 mm compr.; estípulas $1,3-1,7 \times 0,9-1,2 \mathrm{~mm}$, ovadas, margem inteira. Inflorescências 5,8-10,2 cm compr.; raque glabra; brácteas $1,5-2,3 \times 3,3-4 \mathrm{~mm}$, elípticas a depresso ovadas; glândulas discoides sésseis a subsésseis. Flores estaminadas amarelas, 1,6-3,6 mm compr., címulas com 8-22 flores; bractéolas, 0,5-1,4 × $0,2-0,4 \mathrm{~mm}$, oblanceoladas; pedicelos $0,6-1,4 \mathrm{~mm}$ compr.; sépalas $0,8-1,3 \mathrm{~mm}$ compr., ápice recortado, glabras. Flores pistiladas verdes, ca. 3,4 mm compr., sésseis; sépalas 3, 2-3×2-2,1 mm, largo-obovadas, livres, margem inteira, face abaxial glabra; ovários $1,1-2,4 \times 0,8-1,8 \mathrm{~mm}$, globosos, glabros; estiletes 


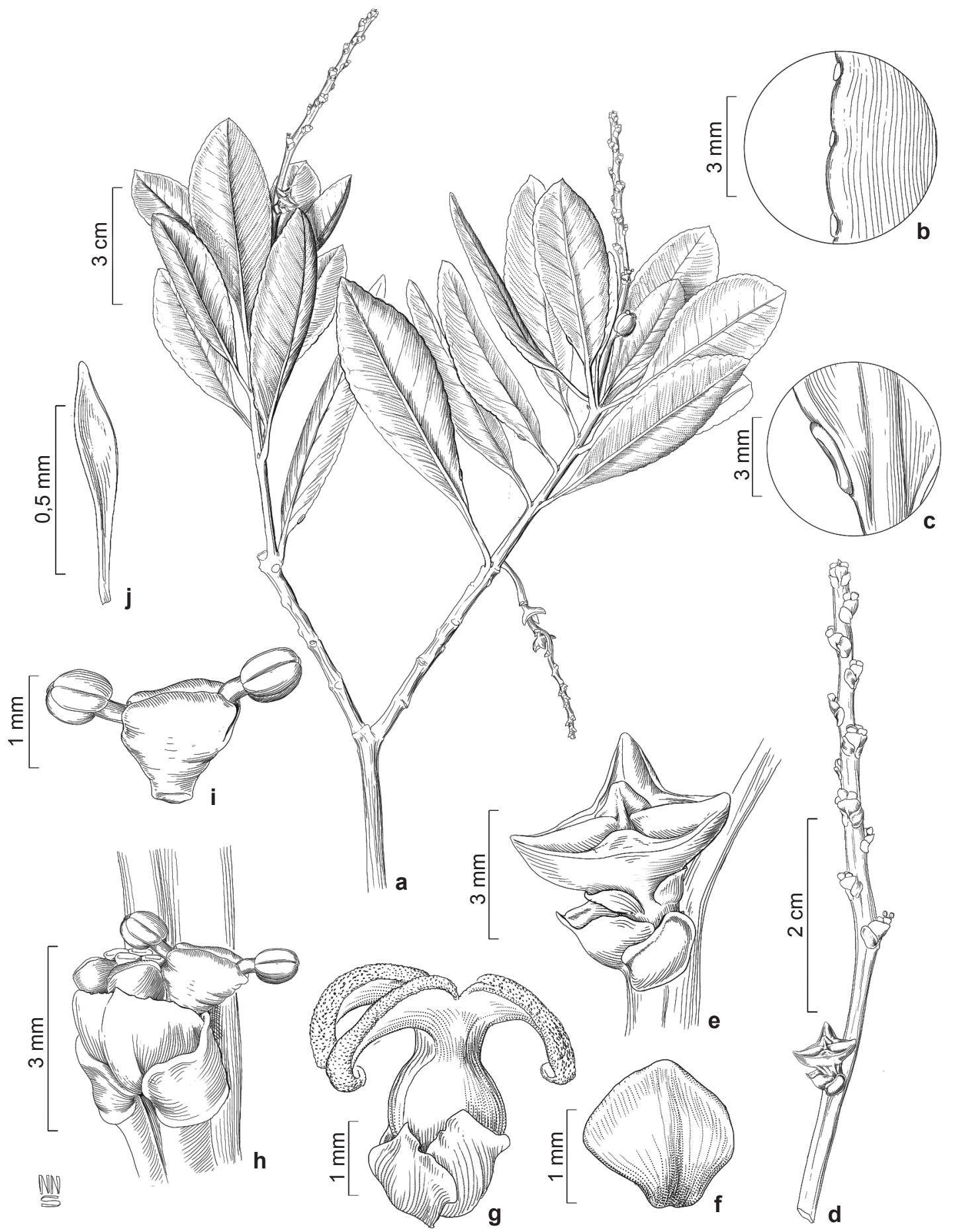

Figura 8-a-j. Stillingia uleana - a. ramo fértil; b. detalhe da margem foliar com glândulas; c. glândulas na base do limbo; d. inflorescência; e. carpidióforo e brácteas com glândulas; f. sépala da flor pistilada; g. flor pistilada; h. címula estaminada; i. flor estaminada; j. bractéola da flor estaminada. (a-g. F. Hurbath 443/549).

Figure 8 - a-j. Stillingia uleana - a. flower branch; b. detail of the leaf blade margin with sessil glands; c. glands at the base of leaf blade; d. inflorescence; e. carpidiophore and bracts with glands; f. sepal of pistillate flower; g. pistillate flower; h. staminate cymule; i. staminate flower; j. bracteole of staminate flower.(a-g. F. Hurbath 443/549). 
3 , unidos $1 / 3$, glabros. Frutos imaturos, $7 \times 5$ $\mathrm{mm}$, elipsoides. Sementes 4,4-4,5 × 3,2-3,5 mm, ovoides. Carpidióforos 2,5 × 4,6-4,9 mm.

Material examinado: Alto do Morro do Cachoeirão, 11.V.2012, fl., F. Hurbath 295 (ALCB). Garimpo da Ametistas, 22.I.2013, fl. e fr., F. Hurbath 443 (ALCB). Campo Rupestre do Xaxá, 23.V.2013, fl. e fr., F. Hurbath 549 (ALCB). Garimpo dos Areiões, 25.V.2013, fl., F. Hurbath 579 (ALCB).

Distribuição: A espécie é endêmica da Bahia (Rogers 1951; BFG 2015).

Comentários: Stillingia uleana pode ser reconhecida por apresentar ramos lenhosos, folhas pecioladas, com limbo elíptico a estreito elíptico, semi-carnosas, e címulas das flores estaminadas com 8-22 flores. Na SGLA, a espécie é encontrada em fitofisionomias de campos rupestres e caatinga sobre afloramentos rochosos. Os indivíduos coletados em altitudes mais elevadas (acima de 900 metros), em solos íngremes, como no alto de um morro no Cachoeirão, apresentaram folhas menores, aglomeradas no ápice dos ramos e com entrenós mais curtos, sugerindo adaptação para sobrevivência em maiores altitudes.

14. Tragia L., Sp. Pl. 2: 980. 1753.

O gênero é pantropical com cerca de 150 espécies, das quais três ocorrem no Brasil. Caracteriza-se por serem ervas a arbustos escandentes, com indumento de tricomas tectores normalmente associado a tricomas urticantes, e pedicelos das flores masculinas articulados (Radcliffe-Smith 2001). Na SGLA, está representado por uma única espécie.

14.1 Tragia volubilis L., Sp. Pl. 2: 980. 1753.

Ervas escandentes, monoicas; látex ausente; ramos não viscosos, pubescentes, tricomas tectores e tricomas urticantes. Folhas alternas, limbos membranáceos a cartáceos, 6,7-7,5 × 5,9-6,6 $\mathrm{cm}$, cordiformes, venação actinódroma, ápice acuminado, margem denteada a duplo-denteada, eglandulosa, base cordada, face adaxial e abaxial glabrescente e hirsutas a pubescentes nas nervuras, ambas com tricomas tectores, face abaxial verde; pecíolos 5-6,6 cm compr.; estípulas 3,7-5,6 × 1,9-2,1 mm, lanceoladas a estreito-triangulares, margem ciliada. Inflorescências tirsos espiciformes, axilares, 3,2-3,6 mm compr.; raque hirsuta; brácteas masculinas $1,3-2 \times 0,4-0,8 \mathrm{~mm}$, brácteas femininas ca. $3 \times 1,7 \mathrm{~mm}$, ambas elípticas a estreito-elípticas. Flores estaminadas verdes, $1,8-2 \mathrm{~mm}$ compr., pedicelos articulados, $0,8-1 \mathrm{~mm}$ compr.; sépalas
$0,8-1,2 \times 0,7-1 \mathrm{~mm}$, largo-ovadas, face abaxial glabrescente; pétalas ausentes; estames 3, 0,8-1 $\mathrm{mm}$ compr. Flores pistiladas verdes, 2,4-2,5 mm compr.; subsésseis; sépalas 6 , levemente desiguais, bisseriadas, 1,5-2,2 × 0,8-1,1 mm, lanceoladas, livres, face abaxial pubescente; pétalas ausentes; ovários ca. 1,1 × 1,2 mm, globosos, puberulentos; estiletes 3, unidos na base formando uma coluna, indivisos, glabros, superfície estigmática lisa. Frutos imaturos $6 \times 8,8 \mathrm{~mm}$, hirsutos, tricomas urticantes. Sementes ca. $2 \times 2,5 \mathrm{~mm}$, elipsoides, muricadas, castanho-avermelhadas ou enegrecidas; carúncula inconspícua.

Material examinado: Estrada $7 \mathrm{~km}$ de Licínio de Almeida para Urandi, 9.XII.2009, fl. e fr., M.L. Guedes 16713 (ALCB, HUEFS).

Material adicional examinado: BRASIL. BAHIA: Salvador, Região Metropolitana, Ilha de Maré, 12.VI.2011, fl. e fr., M.L. Guedes 18355 (ALCB).

Distribuição: Distribui-se a partir do México até a América do Sul e, também, na África (Mulgura De Romero \& Gutierrez De Sanguinetti 1989). Segundo Cordeiro et al (2014), distribui-se nas regiões Nordeste, Norte e Sudeste, e segundo Mulgura De Romero \& Gutierrez De Sanguinetti (1989), distribui-se também nas regiões CentroOeste e Sul.

Comentários: Tragia volubilis caracteriza-se por suas folhas pecioladas, base do limbo cordada, flores masculinas com três estames e estilete com superfície estigmática lisa. Na SGLA, a espécie é encontrada em fitofisionomia de ecótono entre cerrado e caatinga.

\section{Agradecimentos}

Ao Programa de Pós-Graduação PPGVEG/ UNEB. À FAPESB, a bolsa concedida à primeira autora. Aos projetos PRONEM (PNE 1642/2011) e SiB-Br (Proc. 504208/2012-8), o auxílio financeiro aos trabalhos de campo. A última autora agradece ao CNPq, a bolsa PQ.

\section{Referências}

Carneiro-Chaves, M.L.S.; Geraldes, M.C.; Sano, M.C. \& Chambel, L. 2005. Primeiros resultados da datação PB-PB em diamantes carbonatos da Chapada Diamantina (BA) e Rio Jequitinhonha (MG), Serra do Espinhaço. Revista Brasileira de Geociências 35: 419-422.

Carneiro-Torres, D. 2009. Diversidade de Croton L. (Euphorbiaceae) no bioma Caatinga 295 f. Tese de Doutorado. Universidade Estadual de Feira de Santana, Feira de Santana. 295p. 
Carneiro-Torres, D.S.; Cordeiro, I.; Giulietii, A.M.; Berry, P.E. \& Riina, R. 2011. Three new species of Croton (Euphorbiaceae s.s.) from the brazilian Caatinga. Brittonia 63: 122-132.

Caruzo, M.B.R. \& Cordeiro, I. 2007. Sinopse da Tribo Crotoneae Dumort. (Euphorbiaceae s.s.) no estado de São Paulo, Brasil. Hoehnea 34: 571-585.

Caruzo, M.B.R.; Riina, R.; Cordeiro, I. \& Berry, P.E. 2008. Croton campanulatus (Euphorbiaceae s.s.), a new species from the Brazilian Atlantic rain forest. Brittonia 60: 261-264.

Cordeiro, I.; Berry, P.E.; Caruzo, M.B. \& Van EE, B.W. 2008. Croton laceratoglandulosus (Euphorbiaceae s.s) a nem glandular stipulate species from Brazil and Bolivia, and its systematic position based on molecular analysis. Botanical Journal of the Linnean Society 158: 493-498.

BFG. 2015. Growing knowledge: an overview of Seed Plant diversity in Brazil. Rodriguésia 66: 1085-1113.

Costa, H.K.M. 2005. Bahia. In: Xavier, Y.M.A. \& Bezerra, N.F. (orgs.). Gestão legal dos recursos hídricos do Nordeste do Brasil. Fundação Korand Adenauer, Fortaleza. Pp. 35-57.

Dorsey, B.L.; Haevermans, T.; Aubriot, X.; Morawetz, J.J.; Riina, R.; Steinmann, V.W. \& Berry, P.E. 2013. Phylogenetics, morphological evolution, and classification of Euphorbia subgenus Euphorbia. Taxon 62: 291-315.

Esser, H.-J. 2001. Tribes Hippomaneae, Pachystromateae \& Huraeae. In: Radcliffe-Smith, A. (ed.). Genera Euphorbiacearum Royal Botanic Gardens. Cromwell Press Ltd, Kew. Pp. 283-328.

Esser, H.-J. 2012. The Tribe Hippomaneae (Euphorbiaceae) in Brazil. Rodriguésia 63: 209225.

Gaikwad, S.P.; Gore, R.D. \& Garad, K.U. 2012. Astraea lobata (Euphorbiaceae) A New Record for India. Rheedea 22: 131-132.

Gillespie, L.J. 1993. Euphorbiaceae of the Guianas: Annotated species checklist and key to the genera. Brittonia 45: 56-94.

González Ramírez, J. 2010. Euphorbiaceae. In: Hammel, B.E.; Grayum, M.H.; Herrera, C. \& Zamora, N. (eds.). Manual de plantas de Costa Rica. Vol. 5. Missouri Botanical Garden Press, Missouri. Pp. 290-394.

Govaerts, R.; Frodin, D.G. \& Radcliffe-Smith, A. 2000. World checklist and bibliography of Euphorbiaceae (and Pandaceae). Vol. 2. Royal Botanical Gardens, Kew. 1622p.

Harris, J.G. \& Harris, M.W. 1994. Plant identification terminology: an illustrated glossary. $2^{\text {nd }}$ ed. Spring Lake Publishing, Utah. 189p.

Horn, J.W.; Van Ee, B.W.; Morawetz, J.J.; Riina, R.; Steinmann, V.W.; Berry, P.E. \& Wurdack, K.J. 2012. Phylogenetics and the evolution of major structural characters in the giant genus Euphorbia L. (Euphorbiaceae). Molecular Phylogenetics and Evolution 63: 305-326.

IBGE. 2012. Manual técnico da vegetação brasileira. $2^{\mathrm{a}}$ ed. revista e ampliada. Disponível em $<$ http:// biblioteca.ibge.gov.br/visualizacao/livros/liv63011. pdf $>$. Acesso em 22 dezembro 2013.

IUCN 2001. IUCN Red List categories and criteria: Version 3.1. IUCN Species, Survival Commission. IUCN, Gland, Switzerland and Cambridge. 32p.

Judd, W.S.; Campbell, C.S.; Kellogg, E.A.; Stevens, P.F. \& Donoghu, M.J. 2009. Sistemática Vegetal: um enfoque filogenético. Artmed, Porto Alegre. 632p.

Lima, R.L. \& Pirani, J.R. 2008. Three new species of Croton (Euphorbiaceae) from Brazil. Kew Bulletin 63: 121-129.

Melo, A.L. \& Sales, M.F. 2008. O Gênero Cnidoscolus Pohl (Crotonoideae-Euphorbiaceae) no Estado de Pernambuco, Brasil. Acta Botanica Brasilica 22: 806-827.

Mulgura De Romero, M.E. \& Gutierrez De Sanguinetti, M.M. 1989. Actualizacion Taxonômica de Tragia (Euphorbiaceae) para Argentina y Regiones Limitrofes Darwiniana 29: 77-138.

Mueller, J. 1873. Euphorbiaceae. In: Martius, C.F.P. \& Eichler, A.G. (ed.). Flora brasiliensis. Monachii, Lipsiae, Vol. 1, pars 2, pp. 1-752.

Pscheidt, A.C. \& Cordeiro, I. 2012. Sinopse da Tribo Hippomaneae (Euphorbiaceae) no Estado de São Paulo, Brasil. Hoehnea 39: 347-368.

Radcliffe-Smith, A. 2001. Genera Euphorbiacearum. Kew Publishing, Kew. 464p.

Radford, A.E; Dickison, W.C.; Massey, J.R. \& Bell, C.R. 1986. Fundamentals of plant systematics. Harper \& Row, New York. 498p.

Rogers, D.J. 1951. A revision of Stillingia in the new world. Annals of The Missouri Botanical Garden 38: 207-259.

Rogers, D.J. \& Appan, S.G. 1973. Manihot, Manihotoides (Euphorbiaceae). Flora Neotropica. Vol. 3. Hafner Press, New York. 272p. Disponível em <http:// www.jstor.org/stable/4393691>. Acesso em 2 dezembro 2014.

Secco, R.S. 2004. Alchorneae (Alchornea, Aparisthmium e Conceveiba). Flora Neotropica. Vol. 93. The New York Botanical Garden Press, New York. 195p.

Senna, L.M. 1984. Maprounea Aubl. (Euphorbiaceae): Considerações taxonômicas e anatômicas das espécies sul-americanas. Rodriguésia 36: 51-78.

Silva, J.S.; Sales, M.F. \& Carneiro-Torres, D.S. 2009. O gênero Croton (Euphorbiaceae) na microregião do Vale do Ipanema, Pernambuco, Brasil. Rodriguésia 60: 879-901.

Silva, O.L.M.; Cordeiro, I. \& Caruzo, M.B.R. 2014. Synopsis of Euphorbia (Euphorbiaceae) in the State of São Paulo, Brazil. Phytotaxa 181: 193-215. 
Simmons, M.P. \& Hayden, W.J. 1997. Revision of the Cerrado Hemicryptophytic Chamasyce of Boissier's "Pleiadeniae" (Euphorbiaceae). Brittonia 49: 155 180.

Taylor, N. \& Zappi, D. 2004. Cact, of Eastern Brazil. Royal Botanic Gardens, Kew. 499p.

Thiers, B. [continuously updated]. Index Herbariorum: A global directory of public herbaria and associated staff. New York Botanical Garden's Virtual Herbarium. Disponível em $<$ http://sweetgum.nybg. org/ih/>. Acesso em 27 janeiro 2014.

Tropicos.org. Missouri Botanical Garden. Disponível em $<$ http://www.tropicos.org $>$. Acesso em 29 janeiro 2014.

Webster, G.L. 1994. Systematics of the Euphorbiaceae. Annals of the Missouri Botanical Garden 81:33-144.

Webster, G.L. \& Armbruster, W.S. 1991. A synopsis of the neotropical species of Dalechampia (Euphorbiaceae). Botanic Journal of Linnean Society 105: 137-177.

Webster, G.L. \& Burch, D. 1967. Euphorbiaceae. In: Woodson, R.E. \& Schery, R.W. (eds.). Flora of
Panama. Annals of Missouri Botanical Garden 54: 210-350.

Webster, G.L.; Del-Arco-Aguilar, M.J. \& Smith, B.A. 1996. Systematic distribution of foliar trichome types in Croton (Euphorbiaceae). Botanical Journal of the Linnean Society 121: 41-57.

Wurdack, K.J. \& Davis, C.C. 2009. Malpighiales phylogenetics: Gaining ground on one of the most recalcitrant clades in the angiosperm tree of life. American Journal of Botany 96: 1551-1570.

Wurdack, K.J.; Hoffmann, P. \& Chase, M.W. 2005. Molecular phylogenetic analysis of uniovulate Euphorbiaceae (Euphorbiaceae sensu stricto) using plastid rbcL and trnLtrnF sequences. American Journal of Botany 92: 1397-1420.

Zappi, D. 2008. Fitofisionomia da Caatinga associada à Cadeia do Espinhaço. In: Azevedo, A.A.; Fonseca, R.F. \& Machado, R.B. (eds.). Conservação Internacional. Cadeia do Espinhaço: avaliação do conhecimento científico e prioridade de conservação. Megadiversidade 4: 33-37. 